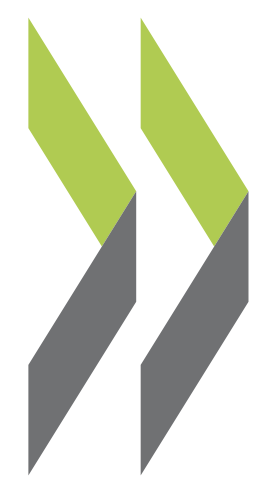

OECD Economics Department Working Papers No. 1694

Constraints and demands on public finances: Considerations of resilient fiscal policy

\section{Kukasz Rawdanowicz,}

Sébastien Turban,

Jörg Haas,

David Crowe,

Valentine Millot 


\section{ECONOMICS DEPARTMENT}

\section{CONSTRAINTS AND DEMANDS ON PUBLIC FINANCES: CONSIDERATIONS OF RESILIENT FISCAL POLICY}

\section{ECONOMICS DEPARTMENT WORKING PAPERS No. 1694}

By Łukasz Rawdanowicz, Sébastien Turban, Jörg Haas, David Crowe and Valentine Millot

OECD Working Papers should not be reported as representing the official views of the OECD or of its member countries. The opinions expressed and arguments employed are those of the author(s).

Authorised for publication by Luiz de Mello, Director, Policy Studies Branch, Economics Department.

All Economics Department Working Papers are available at www.oecd.org/eco/workingpapers

JT03487709 
OECD Working Papers should not be reported as representing the official views of the OECD or of its member countries. The opinions expressed and arguments employed are those of the author(s).

Working Papers describe preliminary results or research in progress by the author(s) and are published to stimulate discussion on a broad range of issues on which the OECD works.

Comments on Working Papers are welcomed, and may be sent to OECD Economics Department, 2 rue André Pascal, 75775 Paris Cedex 16, France, or by e-mail to eco.contact@oecd.org.

All Economics Department Working Papers are available at www.oecd.org/eco/workingpapers

This document and any map included herein are without prejudice to the status of or sovereignty over any territory, to the delimitation of international frontiers and boundaries and to the name of any territory, city or area.

The statistical data for Israel are supplied by and under the responsibility of the relevant Israeli authorities. The use of such data by the OECD is without prejudice to the status of the Golan Heights, East Jerusalem and Israeli settlements in the West Bank under the terms of international law.

(C) OECD (2021)

You can copy, download or print OECD content for your own use, and you can include excerpts from OECD publications, databases and multimedia products in your own documents, presentations, blogs, websites and teaching materials, provided that suitable acknowledgment of OECD as source and copyright owner is given. All requests for commercial use and translation rights should be submitted to PubRights@oecd.org 


\section{Abstract/Résumé}

\section{Constraints and demands on public finances: Considerations of resilient fiscal policy}

Over the past several decades, public debt has increased substantially in many OECD countries, particularly in the aftermath of recessions. The extent of this increase and the resulting debt levels varied across countries, partly reflecting differences in average budget balances. Despite rising debt, governments' interest payments as a share of GDP have declined, reducing concerns about debt sustainability. Still, high debt levels make public finances vulnerable to negative shocks. Thus, governments will have to balance the need to minimise the risk of fiscal stress and the need to satisfy growing demands on public finances related to population ageing, climate change, low growth, inequalities, accelerated digitalisation and cyclical demand stabilisation. Limitations of various numerical indicators of debt sustainability give some support to a more qualitative assessment of fiscal policy and stress the importance of effective and resilient fiscal frameworks. Credible and transparent fiscal frameworks can help make appropriate policy choices, which are affected by numerous political biases and constraints. However, such frameworks do not guarantee positive outcomes. Further research on interactions between various elements of such frameworks, such as fiscal rules, medium-term expenditure plans, budget transparency and independent fiscal institutions, is needed.

JEL classification codes: E61, E62, H11, H20, H50, H62, H63

Keywords: sovereign debt; debt sustainability; public finances; fiscal frameworks; fiscal rules; independent fiscal institutions.

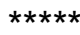 \\ Contraintes et demandes sur les finances publiques: Considérations pour une politique budgétaire résiliente}

Au cours des dernières décennies, la dette publique a considérablement augmenté dans de nombreux pays de l'OCDE, en particulier à la suite des récessions. L'ampleur de cette augmentation et les niveaux d'endettement qui en ont résulté diffèrent selon les pays, reflétant en partie des différences dans les soldes budgétaires moyens. Malgré l'augmentation de la dette, les paiements d'intérêts des gouvernements en pourcentage du PIB ont diminué, ce qui réduit les inquiétudes quant à la soutenabilité de la dette. Néanmoins, les niveaux élevés d'endettement rendent les finances publiques vulnérables aux chocs négatifs. Ainsi, les gouvernements devront trouver un équilibre entre la nécessité de minimiser le risque de tensions budgétaires et la nécessité de satisfaire les demandes croissantes sur les finances publiques liées au vieillissement de la population, au changement climatique, à la croissance faible, aux inégalités, à l'accélération de la numérisation, et à la stabilisation de la demande conjoncturelle. Les limites des divers indicateurs quantitatifs de soutenabilité de la dette plaident dans une certaine mesure en faveur d'une évaluation plus qualitative de la politique budgétaire et soulignent l'importance de cadres budgétaires efficaces et résilients. Des cadres budgétaires crédibles et transparents peuvent aider à faire des choix politiques appropriés, ces choix étant affectés par de nombreux biais et contraintes politiques. Cependant, de tels cadres ne garantissent pas des résultats positifs. Des recherches plus approfondies sur les interactions entre divers éléments de ces cadres, tels que les règles budgétaires, les plans de dépenses à moyen terme, la transparence budgétaire et les institutions budgétaires indépendantes, sont nécessaires.

JEL classification codes: E61, E62, H11, H20, H50, H62, H63

Mots-clés : dette souveraine; soutenabilité de la dette; finances publiques; cadres budgétaires; règles budgétaires; institutions budgétaires indépendantes. 


\section{Table of contents}

Constraints and demands on public finances: Considerations of resilient fiscal policy 6

1. Introduction 6

2. Fiscal trends over the past five decades $\quad 8$

2.1. Government debt has increased over the past decades $\quad 8$

2.2. Government interest payments on debt declined 14

3. Current and future fiscal policy challenges 16

3.1. Challenges with defining and operationalising sovereign debt sustainability 16

3.2. Vulnerabilities from high sovereign debt 20

3.3. Population ageing will put upward pressure on public pension, health and long-term care expenditure that labour market reforms can help alleviate

3.4. Low growth hampers debt sustainability and the achievement of social objectives, calling for ambitious structural reforms and higher public investment

3.5. Growing inequality adds to fiscal challenges and requires changes in tax and spending policies

3.6. Accelerating digitalisation creates opportunities but also challenges for public finances $\quad 27$

3.7. Climate change and policies to mitigate and adapt to it will have profound implications for public finances

3.8. Health care spending may add to fiscal pressures

4. Effective fiscal frameworks for resilient public finances 31

4.1. Political incentives and social constraints tend to weaken fiscal prudence 32

4.2. Fiscal rules: Theoretical benefits and practical challenges 33

$\begin{array}{ll}\text { 4.3. The role of independent fiscal institutions } & 37\end{array}$

References 41

Annex A. Country-specific charts with the main fiscal variables 55

Annex B. Decomposition of debt dynamics and debt measurement issues 62

Decomposition of debt dynamics and estimates of the effective interest rate paid on debt $\quad 62$

$\begin{array}{ll}\text { Definition of gross debt } & 63\end{array}$

Annex C. Debt stabilisation with negative interest-growth differentials 67

Annex D. Measuring pro-cyclicality of discretionary fiscal policy 69

Tables

Table 1. Political economy biases affecting fiscal outcomes 33

Table 2. Advantages and drawbacks of existing fiscal rules $\quad 36$

Table 3. Most independent fiscal institutions are young 38

Table A B.1. Comparison of annual average contributions to changes in debt according to different versions of debt decompositions 


\section{Figures}

Figure 1. Government debt has increased in the OECD over the past decades 9

Figure 2. Decomposition of the average annual change in the debt-to-GDP ratio 9

Figure 3. The largest debt increases were associated with economic crises and growth slowdowns 11

Figure 4. Average fiscal performance in the aftermath of recessions 12

Figure 5. Long-term trends in primary revenue and expenditure 13

Figure 6. Government interest payments declined despite rising gross debt 15

Figure 7. Interest rate-growth differentials have decreased over the last three decades 15

Figure 8. Episodes of large and prolonged sovereign debt reductions 18

Figure 9. Illustrative vulnerabilities related to high debt 22

Figure 10. Potential future fiscal pressure under unchanged policies to keep government debt ratios stable 23

Figure 11. Potential future fiscal pressure to keep public debt ratio at current level with reforms to labour market and retirement policies

Figure 12. Frequency of discretionary fiscal easing during cyclical upswings

Figure 13. National fiscal rules are diverse and widespread across the OECD countries 35

Figure 14. Mandates and resources of IFIs vary widely across the OECD countries 37

Figure A A.1. Evolution of the main fiscal variables for individual countries 55

Figure A B.1. Differences in the effective interest paid on debt according to different debt definitions 66

$\begin{array}{ll}\text { Figure A C.1. Stabilisation of the debt-to-GDP ratio with a negative } r-g & 68\end{array}$

Figure A D.1. Discretionary fiscal policy tends to be pro-cyclical 70

Figure A D.2. Average annual change in the underlying primary balance 71

\section{Boxes}

Box 1. Main findings

Box 2. Country experiences with large and prolonged sovereign debt reductions 17

Box 3. The fiscal pressure indicator and the impact of structural reforms in the OECD long-term economic projections

Box 4. The role of medium-term expenditure frameworks and budgetary transparency 32

Box 5. Characteristics of fiscal rules differ across OECD countries $\quad 35$

Box 6. Country experience with independent fiscal institutions $\quad 39$ 


\title{
Constraints and demands on public finances: Considerations of resilient fiscal policy
}

\author{
By Łukasz Rawdanowicz, Sébastien Turban, Jörg Haas, David Crowe and Valentine Millot ${ }^{1}$
}

\section{Introduction}

Since the seminal article by Musgrave $\left(1956_{[1]}\right)$, which sets out key functions of a government (allocation of public goods, income redistribution and economic stabilisation), challenges with designing fiscal policy have been well known. They involve trade-offs when trying to achieve multiple objectives, and co-ordination challenges as each objective can be achieved with multiple measures. Thus, efficiency losses can arise from conflicting policy instruments and efficiency gains can be obtained when policy instruments are complementary (Tinbergen, 1952[2]). While there is a broad agreement that the pursuit of government objectives should not lead to an excessive accumulation of sovereign debt, there is no consensus about the exact conditions when public finances trigger economic and political instability. Moreover, societal preferences about a government's involvement in the economy and its particular functions differ among countries.

The current environment does not fundamentally change the framework for thinking about fiscal policy design, but serious economic, social and environmental challenges with high sovereign debt make some of the trade-offs more difficult, even if current low interest rates attenuate concerns about debt sustainability.

- Questions have been raised about how governments should respond to major long-term challenges, in particular population ageing, growing inequality and climate change, and what will be the impact of such developments and policy responses on public finances. Transitioning to a higher-growth, equitable and low-carbon economy requires decisive actions in many policy domains, involving difficult choices as policy measures to address these challenges differ in their effectiveness, potential distortions and their political acceptability. For instance, reducing some economic activities that involve high greenhouse gas emissions would be beneficial for preventing climate change, but may adversely affect economic growth and employment, at least in the short run (OECD, 2021 $\left.{ }_{[3]}\right)$. Similarly, taxing greenhouse gas emissions and removing subsidies is

\footnotetext{
${ }^{1}$ The authors are economists at the OECD Economics Department. Section 4 benefited from substantial inputs from the Public Management and Budgeting Division of the Directorate for Public Governance. The authors would like to thank Jón Blondal, Laurence Boone, Jarmila Botev, David Bradbury, Bert Brys, Scott Cameron, Luiz de Mello, Alain de Serres, Yvan Guillemette, Stéphane Jacobzone, Åsa Johansson, Florence Mouradian, Zuzana Smidova, Enes Sunel, David Turner, Lisa von Trapp and participants of the Working Party No. 1 on Macroeconomic and Structural Policy Analysis meeting on 14-15 October 2021 for useful comments and inputs; and Michelle Ortiz for editorial assistance.
} 
desirable from the environmental point of view, but may affect lower-income households disproportionally in the absence of offsetting measures. Moreover, the reduced marginal effectiveness of monetary policy stimulus in a low-interest-rate environment also shifts the onus of demand stabilisation onto fiscal policy, which may weigh additionally on public resources.

- Debates about debt sustainability have revived. The necessary fiscal response to the COVID-19 crisis prevented larger declines in employment, income and output, and is paving the way for a sustainable recovery. However, government debt in relation to GDP has reached the highest levels in several decades. Current low bond yields in many OECD countries, supported by accommodative monetary policy, keep interest payments on sovereign debt low. The historically low interest payments may lead to a re-assessment of constraints on fiscal policy and what constitutes sustainable public finances. Still, maintaining high debt raises vulnerability to interest rate increases and growth slowdowns, and increases debt rollover risks.

In this context, the paper describes driving forces behind the increase in government debt over the past five decades in the OECD countries. It reviews issues in defining debt sustainability and identifies growing demands on current and future public finances that add to fiscal pressures. Finally, the paper discusses elements of effective fiscal frameworks which can help to minimise several political biases that tend to favour imprudent policies and procrastination on actions needed to improve future outcomes. The main findings are summarised in Box 1.

\section{Box 1. Main findings}

Over the past several decades, public debt increased substantially in many OECD countries, though the extent of this increase and the resulting debt levels varied across countries:

- Differences in budget balances explain a large share of the cross-country heterogeneity in the debt increase, with interest rate-growth differentials and stock-flow adjustments playing a less important role. High budget surpluses also contributed significantly to large and prolonged debt reductions in the past.

- The largest increases in sovereign debt were associated with recessions as deteriorations in budget balances proved persistent. This reflected apparent asymmetries in business cycles, with deeper troughs and shallower peaks, and a trend decline in real GDP growth and inflation over the past several decades.

Despite the general increase in sovereign debt, governments' interest payments as a share of GDP declined, owing to the concurring fall in interest rates. Current low interest rates reduce concerns about debt sustainability in the medium term, but high debt levels make public finances vulnerable to negative shocks:

- The practical usefulness of models focusing on the debt ratio for assessing debt sustainability has been questioned and predicting sovereign crises proved difficult.

- A negative interest rate-growth differential (the so-called $r$-g) helps to stabilise debt in a very long term. However, an evolution of debt is also determined by the primary balance, and debt could continue to increase in the near term with some combinations of negative $r-g$ and primary budget deficits.

- Limitations of various numerical indicators of debt sustainability give some support to a more qualitative assessment of fiscal policy and stress the importance of effective and resilient fiscal frameworks.

Demands on public finances are growing as a number of long-standing issues affect spending and taxation priorities: 
- Population ageing, the slowdown in economic growth, rising income and wealth inequalities, but also increasingly pressing challenges stemming from the acceleration of digitalisation, climate change and the need for increased health care capacity, including due to the greater awareness of health risks related to the COVID-19 pandemic, are adding pressures on government budgets.

- Moreover, if short and long-term interest rates remain low, fiscal policy may need to contribute more to demand stimulus during downturns, possibly adding to fiscal pressures, because under such conditions the effectiveness of monetary policy stimulus is reduced. Fiscal support may need to go beyond the traditional automatic stabilisers and rely on additional tools, such as direct transfers from government to households conditional on the state of the economy.

Credible and transparent fiscal frameworks can help make appropriate policy choices, which are affected by numerous political biases and constraints, and ensure debt sustainability but they do not guarantee positive outcomes:

- Country experience suggests that well-designed independent fiscal institutions can contribute to sustainable public finances by increasing transparency and accountability, ensuring more accurate macroeconomic forecasts, monitoring the adherence to rules, and providing policy costings and long-term sustainability analysis. Fiscal rules and changes to fiscal frameworks were also instrumental to large and prolonged debt reductions in some countries.

- The design of specific elements of fiscal frameworks, like fiscal rules, medium-term expenditure plans and independent fiscal institutions, is important but their co-ordination and associated synergies are also key to maximising their impact. Further research on these interactions is needed.

- Looking ahead, independent fiscal institutions could play a more active role in assessing longer-term fiscal risks related to the main challenges, in particular climate change.

\section{Fiscal trends over the past five decades}

Over the past decades, sovereign debt has increased in many OECD countries. Differences in budget balances explain a large share of the cross-country heterogeneity in the debt trajectories. The largest increases in sovereign debt were associated with recessions as deteriorations in budget balances proved persistent. This reflects apparent asymmetries in business cycles, with deeper troughs and shallower peaks, and a trend decline in real GDP growth and inflation over the past several decades. However, despite growing debt, interest payments declined, owing to falling bond yields. This section reviews these issues, laying the ground for a discussion of their implications for longer-term challenges in Section 3.

\subsection{Government debt has increased over the past decades}

The median debt-to-GDP ratio for the OECD countries with sufficiently long time series almost tripled between the 1970 s and 2020, reaching nearly $115 \%$ in 2020 (Figure 1, Panel A). ${ }^{2}$ The gap between countries with high and low debt-to-GDP ratios grew over time and the extent of the debt increase differed widely across economies (Figure 1; Annex A). In general, annual increases in debt tended to be more frequent and larger on average than annual declines in debt, explaining the ratcheting up of debt, but also with an important cross-country heterogeneity (Figure 2; Annex A).

\footnotetext{
${ }^{2}$ As measured by general government gross liabilities as defined in the Economic Outlook (see Annex B for debt definitions).
} 
Figure 1. Government debt has increased in the OECD over the past decades

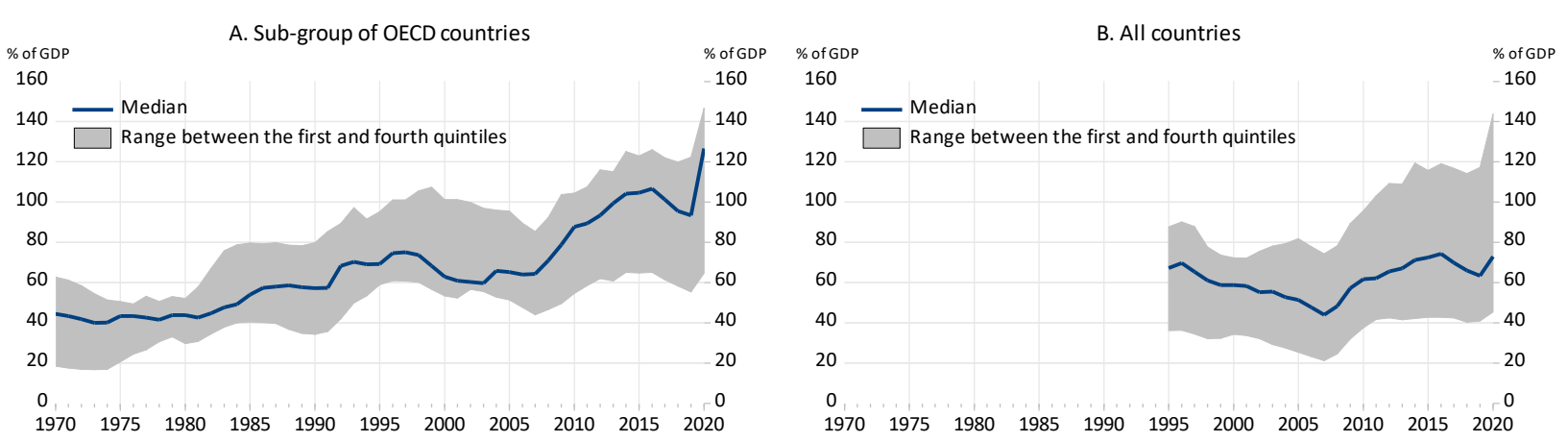

Note: Debt refers to the OECD definition of general government financial liabilities as a ratio to GDP. The sub-group of OECD countries refers to countries for which long time series are available: Austria, Belgium, Canada, Denmark, Finland, France, Germany, Italy, Japan, the Netherlands, Spain, Sweden, Switzerland, the United Kingdom and the United States. All countries include the sub-group of OECD countries with long time series and Australia, Bulgaria, Chile, the Czech Republic, Estonia, Greece, Hungary, Iceland, Ireland, Israel, Korea, Latvia, Lithuania, New Zealand, Poland, Portugal, the Slovak Republic, Slovenia and Romania. As the start of time series differs slightly within the two country groups, distribution moments are calculated only when data for at least $75 \%$ of the number of countries in a given group are available. Source: OECD Economic Outlook database; and authors' calculations.

Figure 2. Decomposition of the average annual change in the debt-to-GDP ratio

Per cent of GDP, country-specific sample between 1970 and 2020

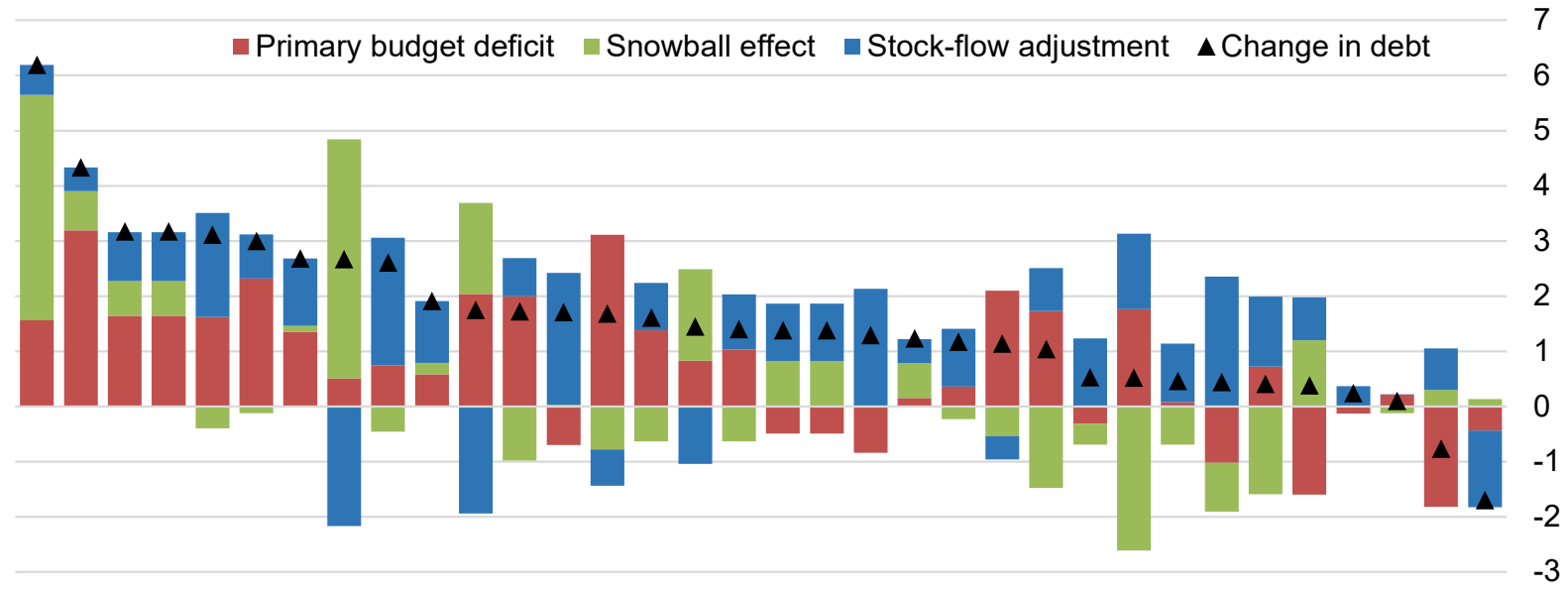

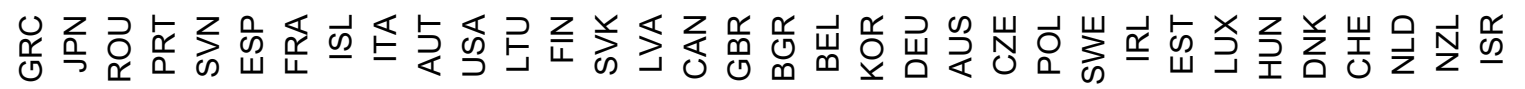

Note: The sample differs across countries depending on data availability between 1970 and 2020 . The snowball effect captures the product of lagged debt and the interest rate-growth differential, and the stock-flow adjustment captures, in general, changes in debt that are not explained by the budget balance (based on a debt dynamics decomposition that does not account explicitly for changes in government financial assets Version 2 in Annex B).

Source: OECD Economic Outlook database; and authors' calculations. 
Differences in budget balances explain a large share of the heterogeneity in the average long-term increase in debt. Not surprisingly, debt increased by more in countries with larger average primary budget deficits (Figure 2). The average changes in debt are also positively correlated with the contribution of the snowball effect, which is a function of the interest rate-growth differential and past debt (Annex B), but the correlation drops significantly when the two outliers (Greece and Iceland, with a highly positive contribution of the snowball effect) are removed.

Deep and prolonged recessions are responsible for the largest increases in debt. The global financial crisis (GFC) and the COVID-19 recession, together with recessions during the sovereign debt crisis in several EU countries after the GFC, led to the biggest increases in debt over the period (Figure 3, Panel A). The increases reflect deteriorations in primary balance and spikes in the snowball effect due to large GDP declines (Figure 3, Panels B and C), as well as bailouts of financial institutions during the GFC. Similar developments were observed during downturns and growth slowdowns in the 1970s, the 1980s and the early 1990s. Consequently, the primary balance surpluses accumulated in the decade before the GFC were not enough to compensate for the accumulation of deficits between the mid-1970s and the mid-1990s, and renewed deterioration of primary budget balances after the GFC and COVID-19 crises wiped out the previous gains (Figure 3, Panel D).

The past two recessions have been larger than recessions in the previous decades, partly reflecting the global nature of the negative shocks and associated negative spillovers among different economies (Figure 4, Panel A). During the GFC, the build-up in private debt and a prolonged impairment of the banking system in some areas both explain the large GDP contraction and the slow recovery, resulting in a considerable asymmetry of economic shocks. In Europe, the recovery was delayed even further by subsequent recessions during the sovereign debt crisis.

The accommodation of recessions with higher budget deficits and higher debt is desirable. However, the deterioration in public finances after recessions tended to be persistent (Figure 4). Higher primary deficits stem primarily from the fact that government expenditure excluding interest payments (the so-called primary expenditure) usually increased or remained constant in nominal terms, while nominal GDP growth remained significantly lower than prior to the recessions, so their share in GDP persistently increased. Enhanced credibility of central banks, globalisation and technological progress have all contributed to lower inflation, while slowing real GDP growth reflected both structural factors like population ageing and accumulation of macroeconomic imbalances. With the exception of the 1970s and the COVID-19 recession, there was very little discretionary spending stimulus as primary expenditure remained fairly constant in relation to potential GDP. ${ }^{3}$ By contrast, primary revenue moved closely in line with nominal GDP and its share in GDP remained broadly unchanged, i.e. the declines in nominal revenue was almost entirely cyclical.

\footnotetext{
${ }^{3}$ According to the OECD methodology of the cyclical adjustment of budget variables (Price, Dang and Botev, 2015 [169]), only a small share of primary expenditure is assumed cyclical and thus there is little difference between cyclically-adjusted and unadjusted series.
} 
Figure 3. The largest debt increases were associated with economic crises and growth slowdowns
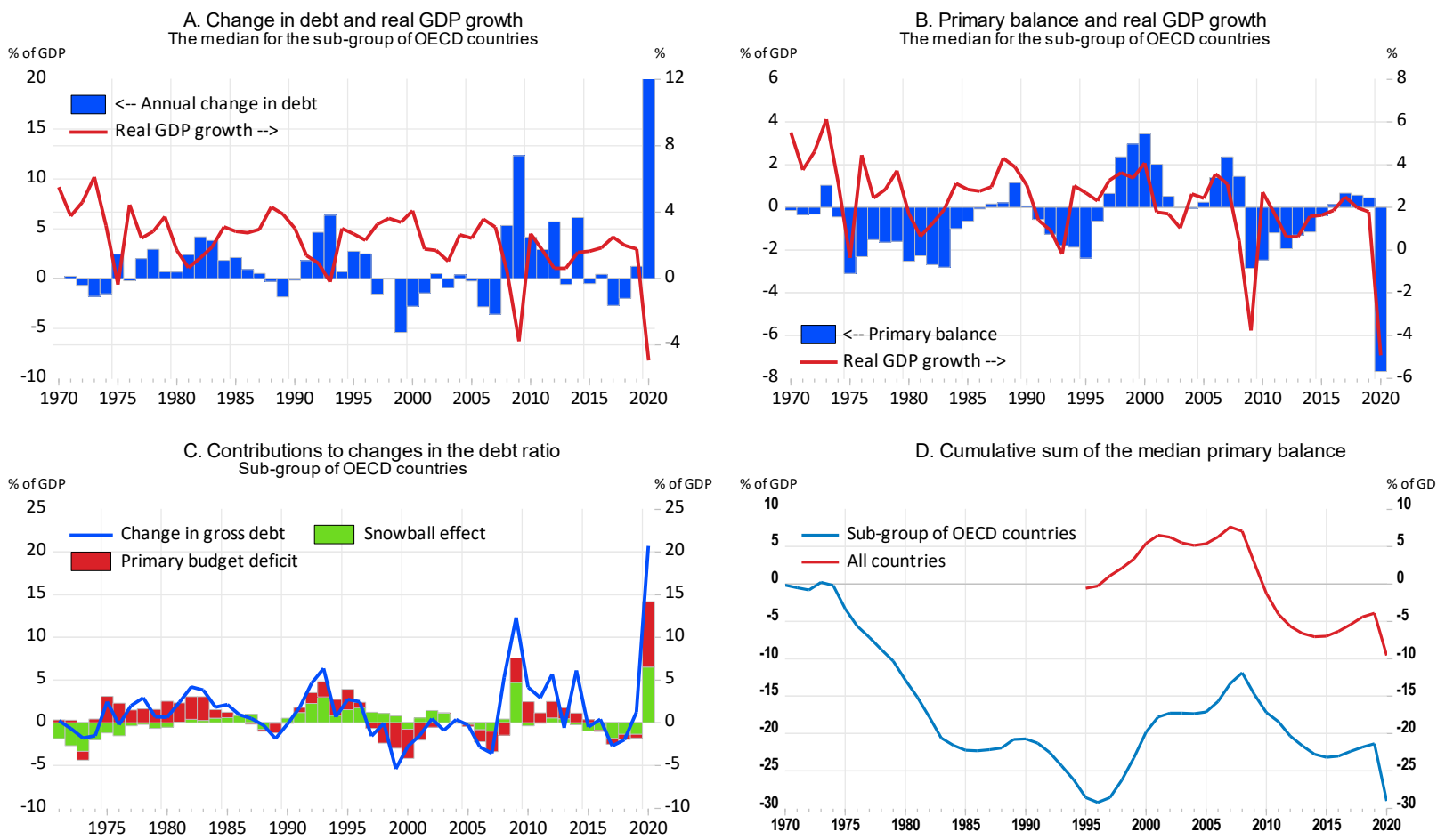

Note: The sub-group of OECD countries refers to countries for which long time series are available: Austria, Belgium, Canada, Denmark, Finland, France, Germany, Italy, Japan, the Netherlands, Spain, Sweden, Switzerland, the United Kingdom and the United States. All countries include the sub-group of countries with long time series and Australia, Bulgaria, Chile, the Czech Republic, Estonia, Greece, Hungary, Iceland, Ireland, Israel, Korea, Latvia, Lithuania, New Zealand, Poland, Portugal, the Slovak Republic, Slovenia and Romania. As the start of time series differs slightly in the group of selected country, medians are calculated only when data for at least $75 \%$ of the number of countries in the group are available. In Panel C, the snowball effect captures the product of lagged debt and the interest rate-growth differential (based on a debt dynamics decomposition that does not account explicitly for changes in government financial assets - Version 2 in Annex B). In Panel D, the median primary surpluses are cumulative sums from the first year shown.

Source: OECD Economic Outlook database; and authors' calculations. 
Figure 4. Average fiscal performance in the aftermath of recessions
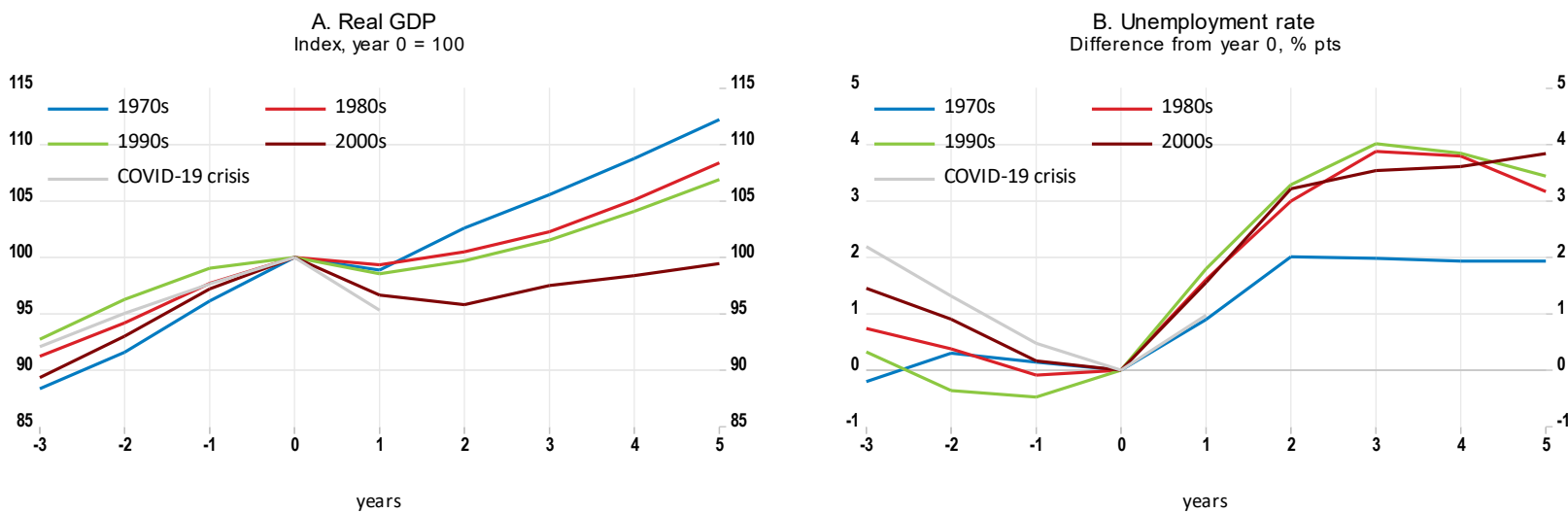

C. Primary balance

Difference from year $0, \%$ pts

Difference from year $0, \%$ pts
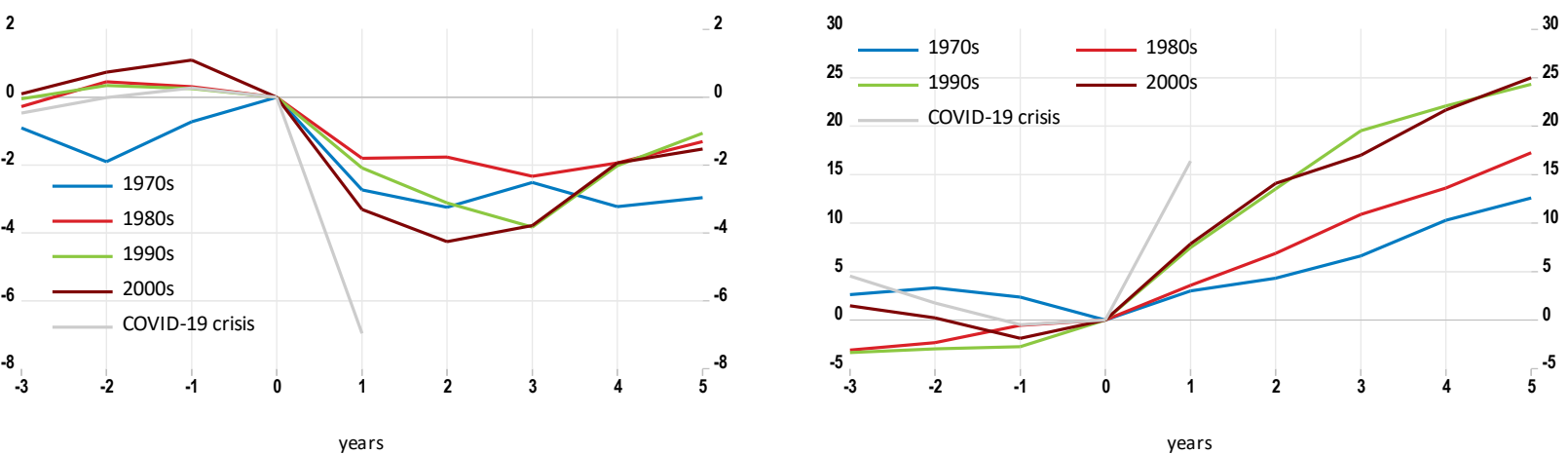

E. Primary revenue
Difference from year $0, \%$ pts

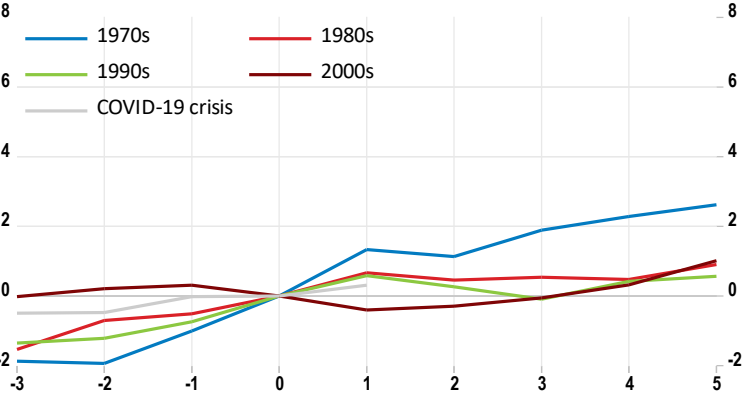

F. Primary spending Difference from year $0 \%$ pts

years

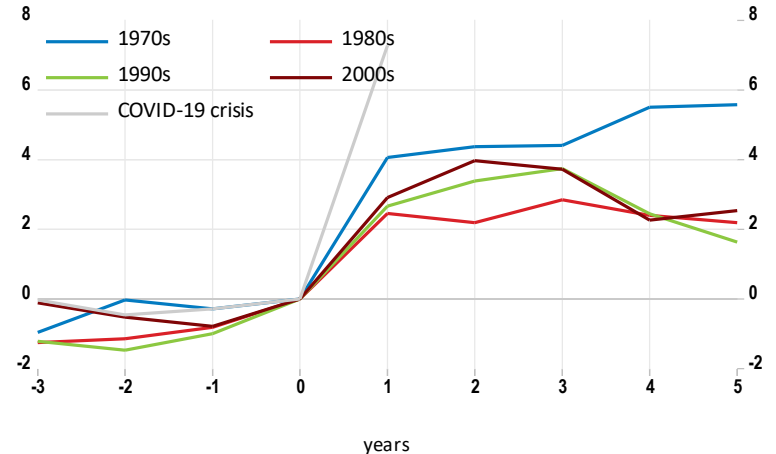

Note: Mean values across countries with recessions starting in the indicated decade and for which data for all indicators are available. Recessions are defined as negative real GDP growth for at least one year at annual frequency. Year 0 refers to the year preceding the recession. If real GDP declines within four years after the previous recession, it is not counted as a new recession. For many EU countries, recession episodes in the 2000s capture the global financial crisis and the subsequent sovereign debt crisis as one recession. Country coverage varies across the decades depending on data availability: the 1970s cover seven recessions; the 1980s cover ten recessions; the 1990s cover 17 recessions; the 2000s cover 35 recessions; and the COVID-19 crisis covers 30 recessions.

Source: OECD Economic Outlook database; and authors' calculations. 
Public expenditure and revenue have increased on average over the past five decades, although average trends mask cross-country heterogeneity (Figure 5, Panel A; Annex A). Among the OECD countries for which data are available since 1970, primary revenue (i.e. total revenue less interest income) had increased steadily between 1970 and 1990 and has stabilised afterwards. Primary expenditure has also increased, but its ratio to GDP varied significantly around the upward trend as expenditure is less cyclical than revenue. On average, the primary revenue has been above its 1970-2020 average since 1986 and has hovered between $41 \%$ and $44 \%$ of GDP (excluding the COVID-19 recession). Primary expenditure have varied between $40 \%$ and $46 \%$ of GDP in the same period, declining for nearly a decade in the 1990 s.

\section{Figure 5. Long-term trends in primary revenue and expenditure}

Panel A. Average ratio of primary expenditure and revenue to GDP

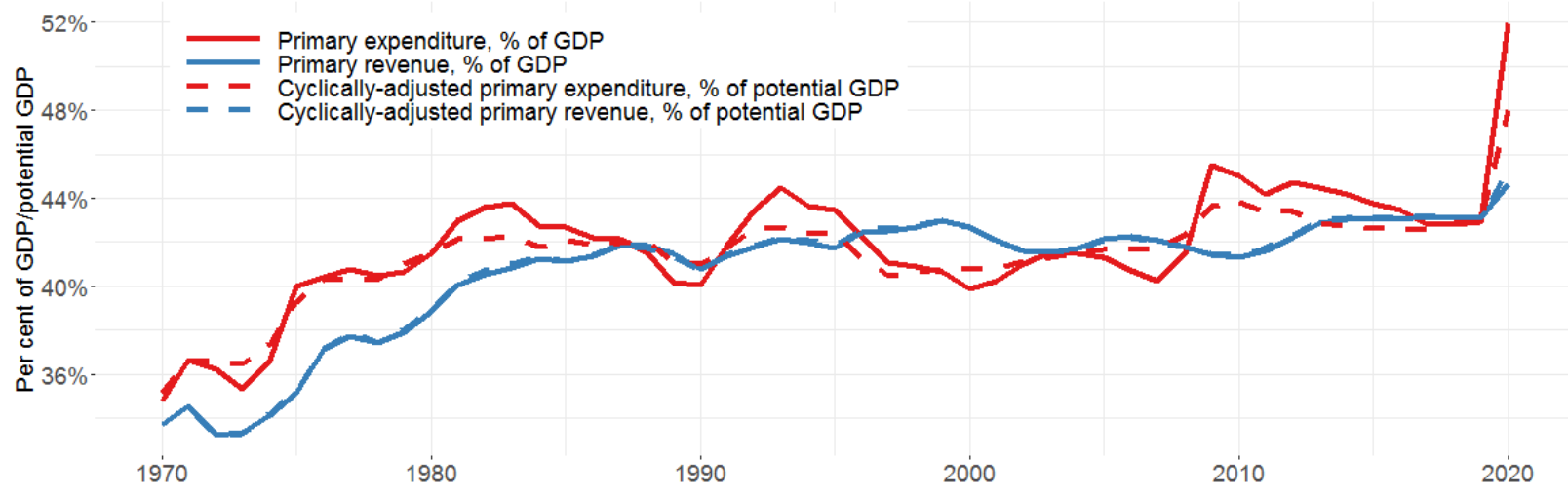

Panel B. Selected public social expenditure in the OECD countries

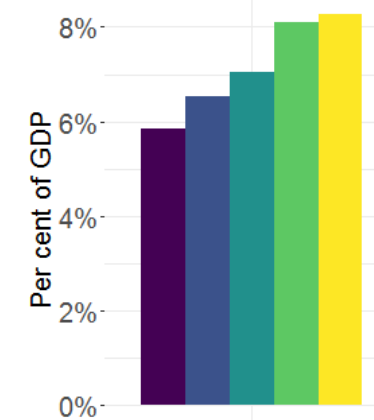

Old age and survivors

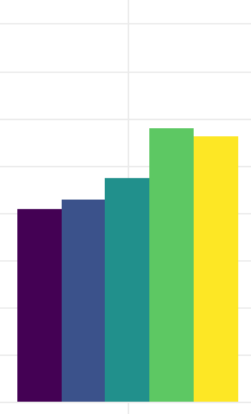

Health

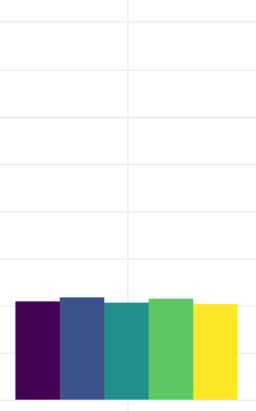

Incapacity
Family and Housing

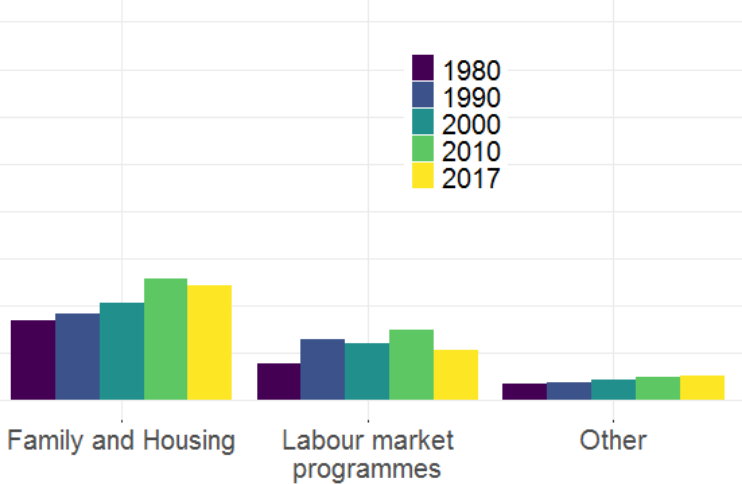

Note: Panel A shows the unweighted average for the sub-group of 15 OECD countries for which long time series are available (Austria, Belgium, Canada, Denmark, Finland, France, Germany, Italy, Japan, the Netherlands, Spain, Sweden, Switzerland, the United Kingdom and the United States). In Panel B, public expenditures shown from the OECD Social Expenditure (SOCX) database are not exactly comparable to government expenditures from the national accounts. Labour market programmes include unemployment benefits and expenditures on active labour market programmes. The OECD average in the SOCX database is an unweighted average of 36 OECD countries. Data before 1999 cover only 23 countries.

Source: OECD Economic Outlook database; OECD Social Expenditure database; and authors' calculations.

The general increase in the size of government spending in the past 50 years is linked mainly to growth in health and pension expenditures, which were accompanied by increases in all types of revenues including 
social contributions. ${ }^{4}$ Dynamic growth at the turn of the century steadied the expenditure ratio on social protection and led to a reduction in unemployment and incapacity-related benefits, while revenues grew in line with activity. Finally, the GFC resulted in an increase in the ratio of social protection expenditure to GDP, as growth of benefits outstripped nominal GDP growth (Figure 5, Panel B).

\subsection{Government interest payments on debt declined}

Government interest payments declined since the 1980s despite rising debt, reaching just above $1 \%$ of GDP in the median OECD economy (Figure 6, Panels A and B). This was possible due to falling nominal and real longer-term government bond yields that started in the late 1980s and the early 1990s (Figure 6 , Panels $C$ and D). Theoretical arguments, stylised facts and calibrated models suggest three broad explanations for the fall in real interest rates: 1) the rising imbalance between desired saving and investment, being significantly affected by demographic changes and inequality; 2) demand for safe assets outstripping supply of such assets; and 3) monetary policy in advanced economies, with policy rates being eased aggressively during successive recessions and not reverted to pre-crisis levels due to the trend decline in inflation. ${ }^{5}$ However, there has been little empirical testing of their joint relevance in a unified econometric framework and the contributions of each factor remain uncertain (Rawdanowicz, Hammouch and Kasai, 2017 $[4])^{6}$

The falling interest rates helped lower the trend interest-growth differential $(r-g)$, mitigating the increase in gross debt. While there are various ways to calculate the effective interest rate paid on government debt, all of them follow similar downward trends from the early 1990s, with sporadic increases during recessions. However, the level of the effective interest rate paid on debt and, in some years the sign of $r-g$ vary across the methods, making the assessment of $r-g$ and its contribution to debt changes difficult (Figure 7; Annex B).

\footnotetext{
${ }^{4}$ For example, among 14 OECD countries with long time series (Austria, Belgium, Canada, Denmark, Finland, France, Germany, Italy, Japan, the Netherlands, Spain, Sweden, the United Kingdom and the United States) for both primary expenditure in the OECD Economic Outlook database and social expenditure in the SOCX database, the average change in primary expenditure is 2.5 points of GDP, while the increase in health, pensions and survivors benefits was 5.0 points. Moreover, between 1960 and 1981, the unweighted average of total public expenditure for 14-17 OECD countries increased from $29 \%$ to $44 \%$ of GDP, while the average of social expenditure (including education) climbed from $14 \%$ to $24 \%$ of GDP (OECD, $\left.1985_{[183]}\right)$.

${ }^{5}$ For instance, Rachel and Smith $\left(2015_{[85]}\right.$ ) come up with back-of-the-envelope calculations based on a rough calibration of the desired global saving and investment curves and an eclectic set of secular factors affecting desired saving and investment that would require changes in the equilibrium global real interest rate. Several papers use calibrated overlapping-generation models to demonstrate that the decline in the equilibrium real interest rates over the past two decades can be explained to a large extent by demographic shifts (Ikeda and Saito, 2014[173]; Carvalho, Ferrero and Nechio, 2016[175]; Lisack, Sajedi and Thwaites, 2017[176]; Gagnon, Johannsen and López-Salido, $\left.2021_{[174]}\right)$. However, Mian, Straub and Sufi $\left(2021_{[182]}\right)$ suggest that because individual saving rates vary significantly more according to income than according to age in the United States, the concentration of income at the top of the income distribution can better explain the rise in aggregate savings since 1950 compared to demographic trends. Some researchers have tried to explain the decline in risk-free interest rates together with other important macroeconomic trends, including the increasing wedge with the return on private capital, lacklustre investment and falling labour shares in GDP. These contributions emphasised rising risk premia together with rising market power and rising unmeasured intangibles, on top of the standard factors (Caballero, Farhi and Gourinchas, 2017[171]; Farhi and Gourio, 2018[180]; Eggertsson, Mehrotra and Robbins, 2019[172]).
}

\footnotetext{
${ }^{6}$ Several studies tested the role of fundamentals in driving real government bond yields in a (panel) cointegration framework for advanced economies (Orr, Edey and Kennedy, 1995[178]; Poghosyan, 2014[177]; Ciocyte, Muns and Lever, 2016[179]).
} 
Figure 6. Government interest payments declined despite rising gross debt
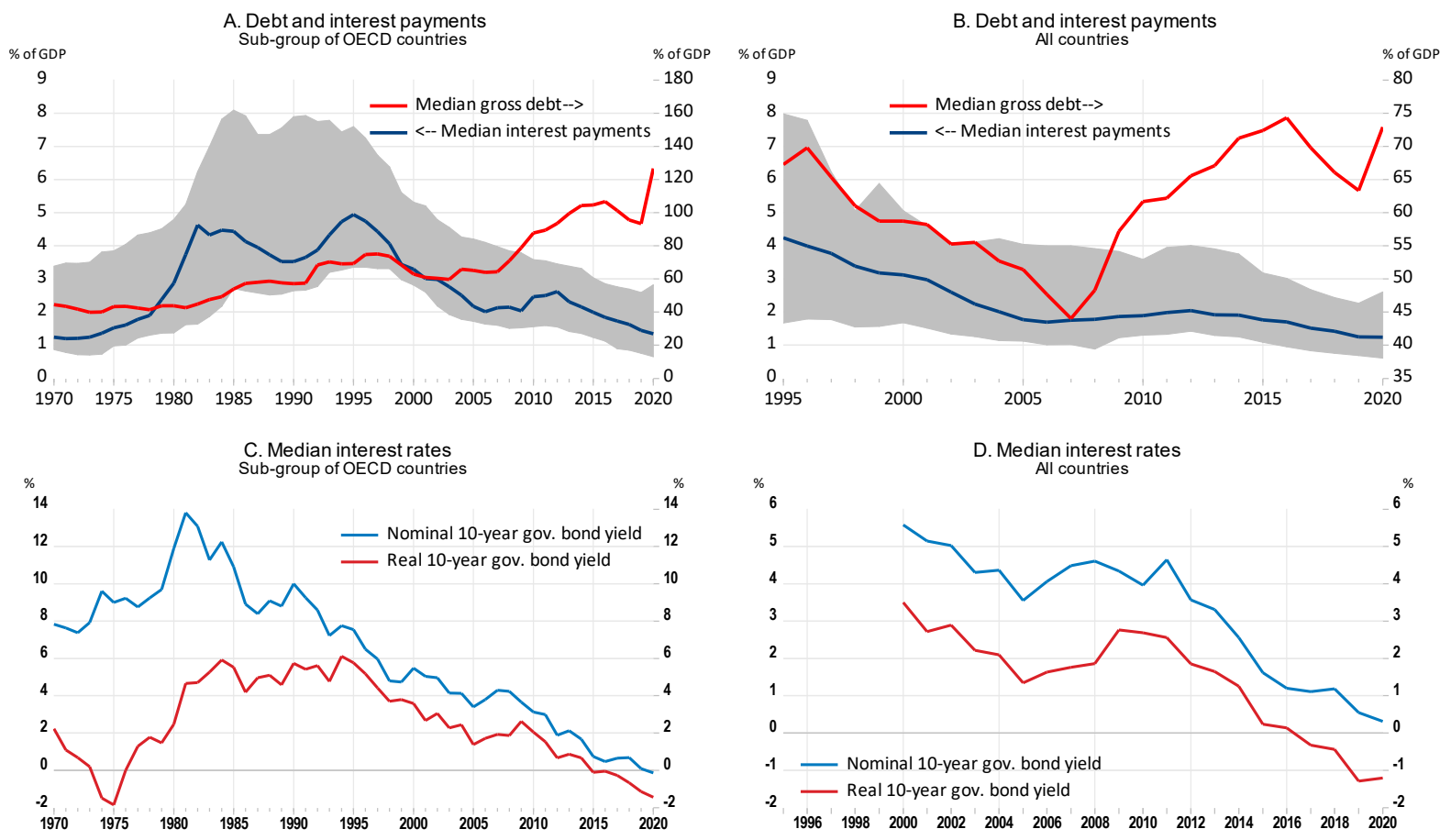

Note: In Panels A and B, the median and the inter-quintile range between the first and fourth quintiles (shaded area) refer to the distribution of general government interest payments as a per cent of GDP. Gross debt refers to the OECD definition of general government financial liabilities. The sub-group of OECD countries refers to countries for which long time series are available: Austria, Belgium, Canada, Denmark, Finland, France, Germany, Italy, Japan, the Netherlands, Spain, Sweden, Switzerland, the United Kingdom and the United States. All countries include the sub-group of the OECD countries with long time series and Australia, Bulgaria, Chile, the Czech Republic, Estonia, Greece, Hungary, Iceland, Ireland, Israel, Korea, Latvia, Lithuania, New Zealand, Poland, Portugal, the Slovak Republic, Slovenia and Romania. As the start of time series differs slightly within the two country groups, medians and the first and fourth quintiles are calculated only when data for at least $75 \%$ of the number of countries in a given group are available. In Panels $C$ and $D$, real 10 -year government bond yields are calculated by subtracting the GDP deflator growth rate from nominal bond yields.

Source: OECD Economic Outlook database; and authors' calculations.

\section{Figure 7. Interest rate-growth differentials have decreased over the last three decades}

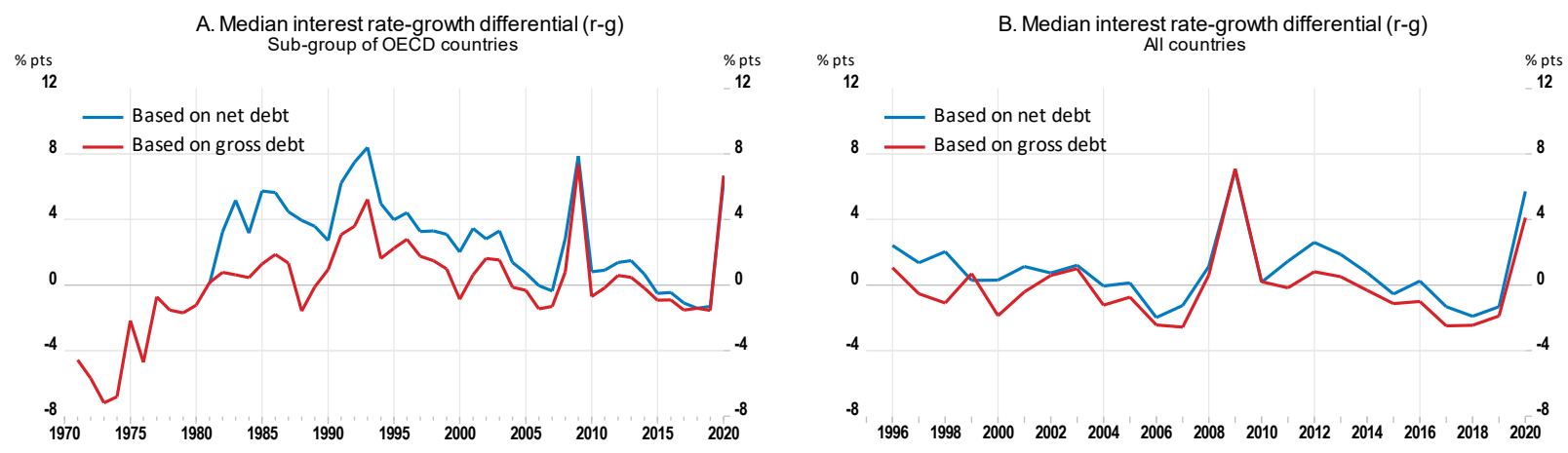

Note: In both panels, the lines indicate the medians of the distribution of interest rate-growth differentials. See Annex B for the definitions of the two versions of the interest rate-growth differentials. The sub-group of OECD countries refers to countries for which long time series are available: Austria, Belgium, Canada, Denmark, Finland, France, Germany, Italy, Japan, the Netherlands, Spain, Sweden, Switzerland, the United Kingdom and the United States. All countries include the sub-group of OECD countries with long time series and Australia, Bulgaria, Chile, the Czech Republic, Estonia, Greece, Hungary, Iceland, Ireland, Israel, Korea, Latvia, Lithuania, New Zealand, Poland, Portugal, the Slovak Republic, Slovenia and Romania. As the start of time series differs slightly within the two country groups, medians are calculated only when data for at least $75 \%$ of the number of countries in a given group are available.

Source: OECD Economic Outlook database; and authors' calculations. 


\section{Current and future fiscal policy challenges}

The fiscal response to the COVID-19 crisis prevented larger declines in employment, income and output, paving the way for a sustainable recovery. However, government debt in relation to GDP has reached the highest levels in the past several decades, exacerbating the pre-crisis long-term build-up in debt (Figure 1). Current low interest rates reduce concerns about debt sustainability in the near term, but high debt levels expose public finances to a number of negative shocks. When deciding about the timing, the size and options for dealing with high debt, governments will have to balance the need to satisfy growing demands on public finances and the need to minimise the risk of fiscal stress.

In this context, this section discusses challenges with defining and assessing sovereign debt sustainability and growing demands on public finances. These demands relate in particular to population ageing, the slowdown in economic growth and rising income and wealth inequalities, but also increasingly pressing challenges stemming from acceleration in digitalisation, climate change and the need for increased health care capacity, including due to the greater awareness of health risks related to the COVID-19 pandemic. Moreover, if interest rates remain low, fiscal policy may need to contribute more to demand stabilisation because monetary policy is less effective under such conditions.

\subsection{Challenges with defining and operationalising sovereign debt sustainability}

In theory, public finance sustainability is often defined in terms of solvency and refers to the coverage of governments' liabilities, including future expenditures, by current assets and future revenues. In other words, the government needs to meet an intertemporal budget constraint where the current stock of debt cannot be larger than future primary surpluses discounted in present value terms. ${ }^{7}$ However, this approach is impracticable as it requires predicting significant future unknowns, and for a very distant future, when complex interactions between fiscal policy and the economy are likely to vary over time and circumstances (Debrun et al., $\left.2019_{[5]}\right)$. The unknowns include the trajectories of macroeconomic trends directly affecting debt dynamics such as economic growth and interest rates. They also refer to political decisions regarding revenue and spending in response to economic, political, demographic, health and climate risks, which are difficult to predict and can vary over time depending on political and economic reality.

In practice, governments decide how to address mounting fiscal pressures. In advanced economies, there has been no sovereign debt default in more than half a century, with the exception of Greece in 2012 and Cyprus in 2013 (Mitchener and Trebesch, 2021 $[6]) .{ }^{8,9}$ In the immediate post-WWII period, large sovereign debts were reduced via high inflation and financial repression resulting in very low real interest rates

\footnotetext{
${ }^{7}$ This is a simplification. When governments can borrow below market interest rates, as investors are willing to pay a liquidity or safety premium, the government earns some seigniorage-like revenues by issuing debt, which need to be included in future surpluses (Mehrotra and Sergeyev, 2020[181]; Reis, 2021 [184]).

${ }^{8}$ Even in these cases, the governments did not miss any payments but arranged debt restructurings that imposed losses on creditors (Zettelmeyer, Trebesch and Gulati, 2013[188]).

${ }^{9}$ The information in this document with reference to "Cyprus" relates to the southern part of the Island. There is no single authority representing both Turkish and Greek Cypriot people on the Island. Turkey recognises the Turkish Republic of Northern Cyprus (TRNC). Until a lasting and equitable solution is found within the context of the United Nations, Turkey shall preserve its position concerning the "Cyprus issue".

Note by all the European Union Member States of the OECD and the European Union: The Republic of Cyprus is recognised by all members of the United Nations with the exception of Turkey. The information in this document relates to the area under the effective control of the Government of the Republic of Cyprus.
} 
(Reinhart and Sbrancia, 2015[7]). ${ }^{10}$ In the past five decades, large and sustained debt reductions have been achieved primarily thanks to high budget surpluses in the context of strong nominal GDP growth (Box 2). Policy decisions affect the economy and investors' expectations. A sudden loss of confidence in government, not necessarily related to long-term solvency, can increase borrowing costs significantly, leading to the so-called spread crises which many advanced economies experienced in the post-WWII period, most recently during the European debt crisis (Mitchener and Trebesch, 2021 [6]). In extreme cases, this can prevent a government from honouring its short-term obligations and result in a self-fulfilling sovereign debt crisis (Pamies and Reut, 2020[8]; De Grauwe and Ji, 2013[9]).

\section{Box 2. Country experiences with large and prolonged sovereign debt reductions}

This box provides stylised facts about 17 episodes of large and prolonged sovereign debt reductions. The identified episodes include only persistent reductions in gross debt (spanning at least five years, but allowing for temporary debt reversals) of at least $15 \%$ of GDP. There are 17 such episodes among OECD countries based on data availability in the OECD Economic Outlook database (Figure 8). Most of them started in the 1990s and ended before the global financial crisis. On average across the episodes, debt was reduced by just over $30 \%$ of GDP over 11 years, but the size and duration varied across the episodes. In many episodes, initial debt was not very high (no higher than $80 \%$ of GDP) and in most cases the debtto-GDP ratio was less than halved (Figure 8 , Panel B).

According to the decomposition of annual average changes in debt (as explained in Annex B), in most of the episodes, debt declined primarily because of a high primary budget surplus - on average $2 \%$ of GDP, but in some cases above 3\% of GDP (Figure 8, Panel A). In two-thirds of the episodes, the interest rategrowth differential was negative, but - in general - the contribution of the snowball effect was not very large. A few countries, benefited also from favourable stock-flow adjustments, in particular Iceland and the Slovak Republic. ${ }^{1}$

Most of the debt reductions took place in an environment of high nominal GDP growth (on average $7 \%$ across countries and years; Figure 8, Panel C), in particular in Hungary and the United Kingdom. The notable exceptions are Germany and Switzerland (2004-2018), where nominal growth was modest but still $r-g$ was negative and the budget surpluses were high. Moreover, in most cases, average growth in nominal primary expenditure was not higher than average nominal GDP growth (Figure 8, Panel C). In some countries (e.g. Finland or Canada), the debt reduction episode also coincided with a substantial depreciation of the domestic currency.

While the economic and political context triggering debt reductions varied across countries, there were a few common themes.

- Growing fiscal pressures. In several episodes, debt reductions were initiated because of prolonged and large debt accumulations, weighing heavily on government interest payments. In some countries at the beginning of debt reduction, interest payments amounted to at least $5 \%$ of GDP and in Belgium and Canada around 10\% of GDP. The debt reductions in the 1990s coincided with falling interest rates and government interest payments.

\footnotetext{
${ }^{10}$ Financial repression has been estimated to have brought 1-5\% of GDP in annual savings between 1945 and 1980 for 12 developed economies (Reinhart and Sbrancia, 2015[7]). In the United States, inflation contributed to a reduction of one third of public debt within a decade after WWII (Aizenman and Marion, 2011 [189]).
} 
Figure 8. Episodes of large and prolonged sovereign debt reductions
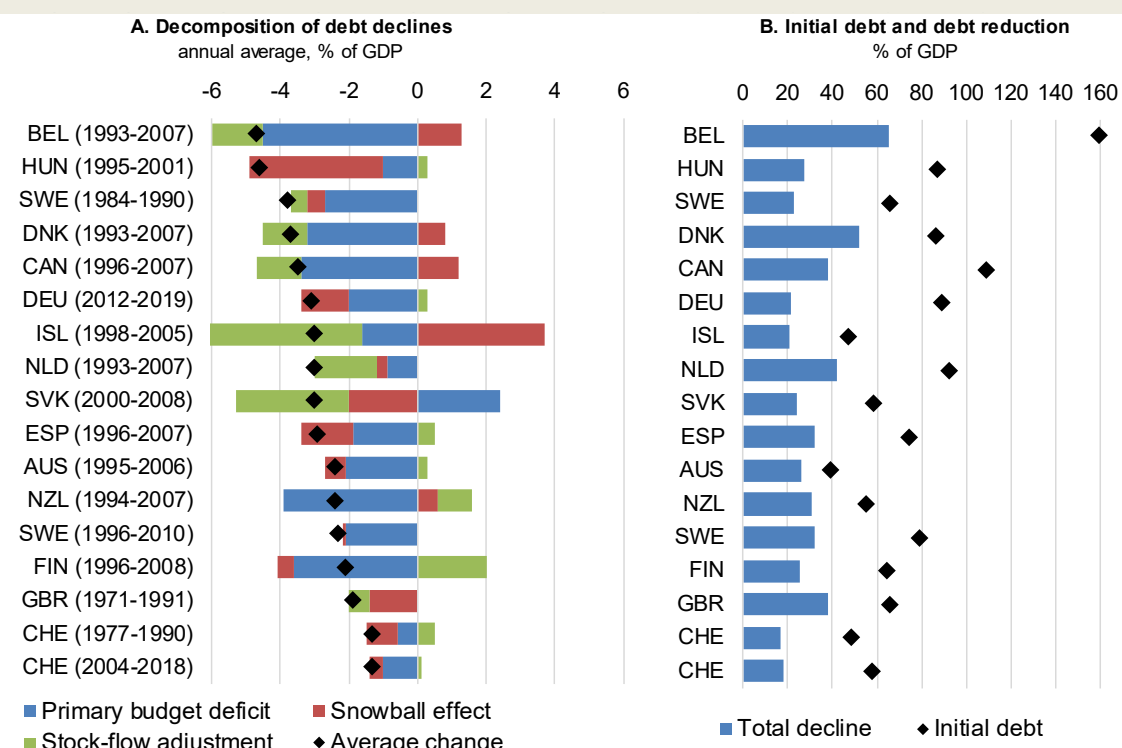

- Total decline $\bullet$ Initial debt

Note: The snowball effect captures the product of lagged gross debt and the interest rate-growth differential (based on the debt dynamics decomposition that does not account explicitly for changes in government financial assets - Version 2 in Annex B).

Source: OECD Economic Outlook database; and authors' calculations.

- Fiscal rules and frameworks. In several EU countries, the desire to fulfil the Maastricht fiscal criteria (budget deficit no higher than $3 \%$ of GDP and government debt below $60 \%$ of GDP) ahead of adoption of the euro contributed to lasting improvement in public finances. In Canada, to deal with large budget deficits of provincial and federal governments in the early-1990s, many provinces voluntarily adopted fiscal rules. The Federal government introduced the Spending Control Act between 1992 and 1995 and since then has generally used non-legislated fiscal targets, helping to achieve high budget surpluses in the subsequent years. In New Zealand, fiscal discipline was improved thanks to the introduction of a new budgetary framework (the 1994 Fiscal Responsibility Act), building on responsible fiscal management principles: debt should be reduced when it is above "prudent levels", ensuring sufficient buffers to deal with future shocks and managing fiscal risks. The act also enforced greater transparency about the fiscal situation and policies.

- Negative economic shocks. In a few countries, severe economic crisis necessitated fiscal adjustments and facilitated overcoming political hurdles to redress public finances. For instance, in Finland the deep recession following a financial crisis in the early 1990s prompted the government to implement large cuts in government spending (including social benefits, public sector wages, subsidies, investment and transfers to sub-central governments), with the aim to restore confidence in financial markets and to achieve a non-inflationary recovery. The impact of these measures on the debt reduction were strengthened by the move to a floating exchange rate which led to a sharp depreciation of the local currency. In Sweden, the severe banking and economic crisis in the early 1990s led the government to implement several structural reforms covering governance of the public finances, tax reforms, liberalisation of the economy, reforming the welfare state (pensions especially), and promoting an export-oriented growth model.

- Relations with subnational governments. In systems with strong subnational governments, national debt reductions may be offset by subnational borrowing. Consistent fiscal practices across different levels of government are thus useful to ensure coherent fiscal policy. Based on the Canadian and Belgian debt reduction episodes, strict enforcement by central government of rules governing the borrowing of subnational units were not required to lower debt. In Belgium, although formal 
mechanisms existed to restrict the debts of regions, they were not used between 1993 and 2007. Instead, the federal government and the regions and communities were party to "Co-operation Agreements" setting out fiscal targets. In Canada, although there were limited formal mechanisms for the federal government to limit provincial deficits, provinces voluntarily adopted legislative fiscal rules.

1. In Iceland, the large negative contribution of the stock-flow adjustment primarily reflects very large interest earnings (on average $5 \%$ of GDP), which are added to the stock-flow adjustment (Annex B). In the Slovak Republic, it reflects a sizeable reduction in the ratio of government financial assets to GDP between 2002 and 2008 , by nearly $30 \%$ of GDP.

Until recently, the main approach to assess public finances sustainability focused on the debt-to-GDP ratio and its forecasted trajectory, in deterministic or stochastic debt sustainability analyses (DSAs). In a deterministic setting, debt projections are presented based on a baseline trajectory of the key debt determinants, in some cases assumed to be exogenous, and the potential impact of shocks can be analysed by shifting parameters (e.g. a level shift in interest rates or growth rates compared to the baseline). The main issue with the deterministic analysis is that it cannot handle a large set of sensitivity analyses in a practical way, which is crucial in view of large uncertainties as discussed above. In contrast, stochastic DSAs generate alternative debt trajectories based on probability distributions for the variables included in the debt dynamics, including the potential correlations between variables such as budget balances, growth and interest rates, or even stock-flow adjustments. Thus, they can provide a probabilistic distribution of debt at various horizons and allow for a broader view of potential risks. Still, they do not fundamentally solve the issue of future unknowns as they frequently assume historical distribution of shocks and unchanged government reaction functions, implying no structural changes in the economy.

In most DSAs, debt is considered sustainable if it does not cross a threshold, above which it would increase permanently. Constraints on maximum feasible primary balances or a significant non-linear reaction of interest rates to the level of debt can generate such a threshold (Botev, Fournier and Mourougane, $2016[10]$ ). In turn, limits to feasible balances can be set exogenously or arise endogenously, for instance, by assuming that rising debt leads to an improvement in the primary balance only up to a point of so-called "fiscal fatigue" (Bohn, 1998 ${ }_{[11]}$; Ghosh et al., 2013 ${ }_{[12]}$ ), or that there are limits to raising revenues as illustrated by the Laffer curve (Bi and Leeper, $2013_{[13]}$ ). The focus of stochastic DSAs has recently shifted to the probability that the debt-to-GDP ratio does not increase over the medium term (Bouabdallah et al., 2017 [14]; Blanchard, Leandro and Zettelmeyer, 2021 [15]; European Commission, 2020[16]).

However, the practical usefulness of models focusing on the debt ratio for assessing debt sustainability has been questioned and their ability to predict sovereign crises proved difficult. The estimated debt sustainability thresholds are highly sensitive to model-specific assumptions, for example on the government's reaction to debt which determines a maximum balance, or on the interest rates' response to debt. The actual link between debt and the occurrence of debt crises has been relatively weak when debt composition has not been properly taken into account (Manasse and Roubini, 2009 ${ }_{[17]}$ ). Similarly, debt levels and sovereign spreads have been disconnected for prolonged periods. ${ }^{11}$ Moreover, there is no consensus about the best metric of debt in terms of the coverage of liabilities and their valuation (Annex B) and how to account for contingent liabilities. ${ }^{12}$

\footnotetext{
${ }^{11}$ For instance, prior to the GFC, government bond spreads among the euro area countries were very small despite persistent differences in debt levels, but during the euro area debt crisis the spreads seemed to increase by more than would be justified by the deterioration in fundamentals (De Grauwe and Ji, 2013[9]).

12 The GFC and the European debt crisis illustrated well that contingent liabilities related to support for financial institutions can raise debt significantly and quickly (Bloch and Fall, 2015[166]; Debrun et al., 2019[5]). During the
} 
Despite the criticism of DSAs based on the debt-to-GDP ratios, some models still provide useful insights. For example, stochastic DSAs illustrate potential risks and the sensitivity of public finance trajectories to different outcomes. Likewise, debt-stabilising indicators can produce illustrative metrics to assess the size of future challenges (Blanchard, 1990 ${ }_{[18]}$; Guillemette and Turner, 2021 ${ }_{[19]}$ ).

Alternative methods or metrics to assess the sustainability of public finances have recently been proposed but they have their shortcomings too. Furman and Summers (2020[20] $)$ argue for focusing on net debt, in contrast to gross debt which does not account for government financial assets, and for using a $2 \%$ threshold for the ratio of real interest payments (deflated by a five-year average inflation) to nominal GDP. ${ }^{13}$ The main advantage of interest payments as an indicator compared to the debt ratio is that it focuses on flow concepts: obligations resulting from accumulated debt, and government revenues (implicitly assuming that revenues co-move with GDP). However, as pointed out by Orszag, Rubin and Stiglitz (2021 [21]), a new anchor based on interest payments is subject to the same uncertainties as the thresholds on debt ratios. In addition, interest payments are likely to change slowly over time (especially with a long maturity of debt and a large stock of debt compared to new financing needs) and when they exceed critical levels, it may be too late and too costly to redress fiscal pressures. Similarly, focusing merely on the negative interest rate-growth differential as a factor ensuring debt sustainability can be risky. Indeed, the persistent negative $r-g$ helps lower debt and, in theory, it ensures that at some point in the future debt will stabilise with any constant primary budget deficit. However, in practice depending on the level of the primary budget balance and $r-g$, such asymptotic stabilisation could imply an initial prolonged and large increase in debt, which may not be politically and economically sustainable (Annex $\mathrm{C}$ ).

Limitations of old and new numerical indicators of debt sustainability have led some scholars to depart from mechanical and precise analyses of these indicators and focus on qualitative assessment of fiscal policy. For instance, Blanchard, Leandro and Zettelmeyer (2021 [15]) argue for using DSAs to give broad indications whether fiscal policy complies with qualitative "standards" such as the conduct of a "prudent" fiscal policy. Similarly, some scholars have argued for focusing on the designs of fiscal policies in order to make it more resilient to future developments (e.g. via debt management or indexation of long-term fiscal programs, Orszag, Rubin and Stiglitz (2021 [21])).

\subsection{Vulnerabilities from high sovereign debt}

Temporary bond yield increases should not raise overall debt servicing costs significantly but risk triggering fiscal distress. A delayed pass-through from market interest rates to total interest payments, reflecting a staggered maturity structure, largely shields budget balances from temporary increases in market bond yields even if they are big and debt is high (Figure 9, Panel A). ${ }^{14}$ Increasing the maturity of newly issued

COVID-19 crisis, several governments have provided large guarantees on loans to companies, which may result in financial losses and higher debt. For instance, Bruegel estimates that France, Germany, Italy, Spain and the United Kingdom committed large amounts of governments' guarantees on loans to businesses (ranging between $13 \%$ and $18 \%$ of GDP), but the take-up by the end of 2020 was substantial only in Spain and Italy (around $12 \%$ and $14 \%$ of GDP, respectively). These estimates are likely overestimated as they include the entire amount of the loans even if the guarantee was partial, and they include loans which were not actually paid out (Bruegel, 23 September 2021 [191]).

${ }^{13}$ For calculating net interest payments in the United States, they also recommend excluding the remittances from the Federal Reserve to the US Treasury, which currently reflect, to a large extent, net profits from holdings of US government bonds (i.e. the difference between interests earned on bond holdings and the interests paid on reserves deposited by financial institutions at the Federal Reserve).

14 The current average remaining debt maturity in the median OECD economy is around 8 years, ranging between below 6 years in Canada, Norway, Poland, Sweden and Turkey to 15 years in the United Kingdom. The effective maturity is, however, shorter due to central banks' holdings of government debt. 
debt can further delay the pass-through (Maravalle and Rawdanowicz, 2018[22]). Many countries have already done so in the aftermath of the GFC (OECD, 2020[23]). Still, temporary bond yield increases may magnify financial stability risks, especially when financial institutions have large exposures to sovereigns, with negative effects on the cost of borrowing for the private sector and on consumer and business confidence, and in turn on economic growth. If such developments undermine investors' trust in sovereign debt sustainability, subsequently, this can amplify negative feedback loops among bond yields, confidence and growth. Even if government continues to meet its obligations, such a "spread" crisis can lead to a recession, involve a temporary loss of access to financing and force government to a pro-cyclical consolidation (Mitchener and Trebesch, 2021 $\left.{ }_{[6]}\right) .{ }^{15}$

The longer-term evolution of government bond yields is highly uncertain and current low effective interest rates in relation to GDP growth do not exclude a possibility of future high sovereign yields and debt rollover problems. Indeed, historically, interest rate-growth differentials were no higher prior to sovereign defaults than in normal times (Mauro and Zhou, 2020[24]). In the next decade or so, interest rates will be determined to a large extent by the evolution of inflation and the resulting responses of monetary policy and financial markets, with different possible outcomes. If the pre-pandemic low-inflation and low-neutral interest rate environment is sustained, policy interest rates and government bond yields will remain low. In contrast, a tighter monetary policy stance and higher inflation risk premia are likely with higher inflation. The latter may result from a reversal of structural disinflationary factors related to the production and distribution of goods and services, or firms' business models and demand structure, observed in the advanced economies in the decades prior to the pandemic (OECD, 2020[25]).

If current high debts are not reduced before the next recession hits, future negative shocks could result in ever-rising debt. Output declines can bring about big increases in the debt-to-GDP ratio through the so-called snowball effect and a cyclical deterioration in the primary balance (Figure 3; Figure 9, Panel B). ${ }^{16}$ Such increases may be difficult to reverse if growth is low and budget deficits are large in the post-shock period (Figure 4). Consequently, high debt may limit the fiscal space which would be available to accommodate future negative shocks and thus undermine the resilience of public finances (Jordà, Schularick and Taylor, 2016 $\left.6_{[26]}\right)$. These limits could be more binding when the pre-shock budget deficit is already large, aggravating the rise in the debt ratio and thus risking spiralling risk premia.

High debt levels raise rollover risks (Figure 9, Panel C). For a given maturity structure, doubling the initial debt level increases the amount of debt to be rolled over proportionally. For instance, with the remaining average maturity of debt (6 years) and initial debt of $160 \%$ of GDP, a country may need to roll nearly $20 \%$ of GDP of debt in the first year; when debt is $80 \%$ of GDP, the amount would still be nearly $10 \%$ of GDP. At current decades-high debt levels, the OECD countries will have to issue significant amounts of bonds in coming years. Some of the rollover risks could be mitigated by managing debt maturity to avoid concentration of large debt rollovers. Central banks' purchases of government bonds could also help. Private investors could be willing to buy bonds in the primary markets, despite debt sustainability concerns, if they knew that they could sell them to the central bank subsequently. However, maintaining positive confidence may require very large (gross) purchases by the central bank.

\footnotetext{
15 In the past two decades, only about $20 \%$ of episodes with severe debt distress ended up in a sovereign default (Mitchener and Trebesch, 2021[6]). The remaining 80\% were so-called sovereign debt crises without default (or spread crises), which occurred in several emerging-market economies, including in Mexico (1994/95), Brazil (1998 and 2001), Turkey (2001) and the Philippines (1998), but also in several EU countries during the euro area sovereign debt crisis.

${ }^{16}$ Even if the shock-induced debt increase does not rise proportionally with the level of initial debt.
} 


\section{Figure 9. Illustrative vulnerabilities related to high debt}

A. Sensitivity of debt dynamics to interest rate shocks

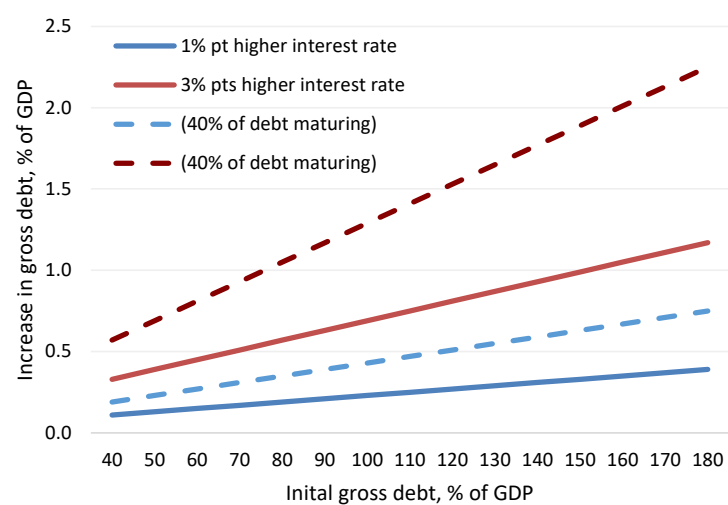

B. Sensitivity of debt dynamics to GDP shocks

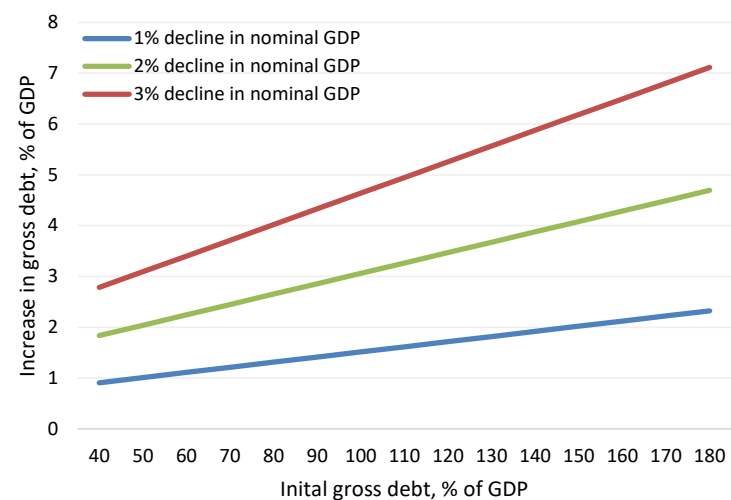

C. Sensitivity of debt rollover to debt maturity

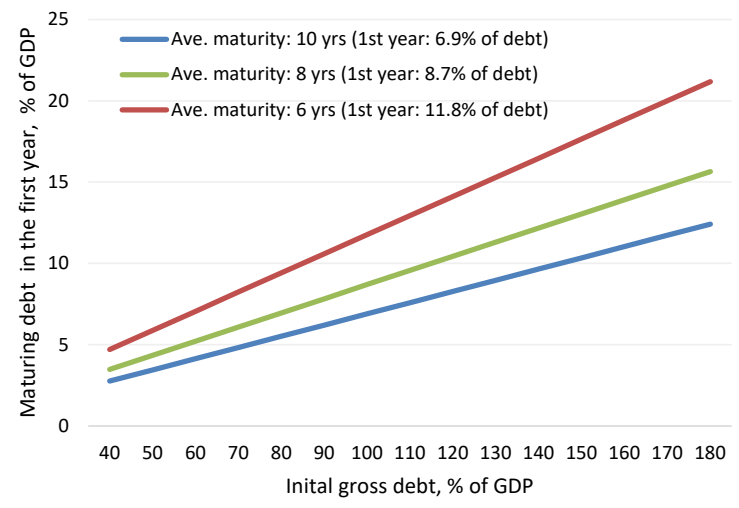

Note: Stylised simulations showing a yearly change in debt due to specific one-year shocks (Panels A and B). In Panel A, the increase in debt reflects only higher interest payments on debt maturing in the year of the shock (solid lines for $20 \%$ of initial debt maturing and dashed lines for $40 \%$ of initial debt maturing); initial debt is indicated on the horizontal axis. In Panel B, the increase in debt reflects a part of the snowball effect $\left(-g /(1+g)^{*} g d_{-1}\right)$, where $g$ is the GDP growth rate and $g d_{-1}$ is the initial stock of gross debt (Annex B), and a cyclical deterioration in the budget balance (based on a cyclical semi-elasticity of 0.5 ) due to a $1 \%, 2 \%$ and $3 \%$ decline in GDP. In Panel C, given the decaying exponential patterns of actual maturity structure in the majority of OECD countries, the indicated stylised average remaining maturities are calibrated so that initial debt is completely rolled-over or paid back over a fixed period and, each year over this period, the share of maturing debt in initial debt declines linearly. The numbers in brackets indicate the share of initial debt which matures in the first year (i.e. the highest share).

Source: Authors' calculations.

\subsection{Population ageing will put upward pressure on public pension, health and long-term care expenditure that labour market reforms can help alleviate}

The population of advanced economies and some emerging-market economies is ageing and this is likely to be associated with rising public expenditure on health, long-term care and pensions, together with declining tax revenues. Such spending already accounts for a third to a half of primary expenditure in some advanced countries and their contribution to overall spending pressures is projected to increase substantially over the next few decades.

According to the OECD long-term projections (Box 3), the median OECD country would require an increase in structural revenue of 8 percentage points of GDP by 2060 to stabilise public debt ratios near current levels, compared to the structural balance in 2021 and in the absence of policy changes (Figure 10). Stabilising debt at lower debt ratios would necessitate an even larger adjustment in the near term, although not in the long run, as a lower debt ratio can be maintained with a lower primary budget 
balance. In most OECD countries, pension and health care expenditures account for at least half of the required increase in revenues in 2060.

One of the most effective ways of alleviating future fiscal pressures stemming from population ageing would be to undertake reforms to labour market policies and public pension programmes to raise employment rates and extend working lives (Rouzet et al., 2019 [27]; Guillemette and Turner, 2021 [19]). Another would be to index long-term fiscal programmes to their underling drivers, such as life expectancy in the case of pensions, which can also help reduce fiscal uncertainty (Orszag, Rubin and Stiglitz, 2021[21]). Many countries have already moved in this, although some of them have later seen some reform reversals (OECD, 2019[28]). According to stylised simulations wherein OECD countries undertake ambitious labour market reforms and link statutory retirement ages to future gains in life expectancy (Box 3), fiscal pressure in 2060 could be reduced substantially relative to a no-reform scenario, by between 2 and 8 percentage points of GDP (Figure 11). The fiscal dividends would mostly accrue due to longer working lives reducing future pension and other primary expenditure as a share of GDP, with much less impact on health expenditure.

\section{Figure 10. Potential future fiscal pressure under unchanged policies to keep government debt ratios stable}

Change from 2021 to 2060 in \% pts of potential GDP

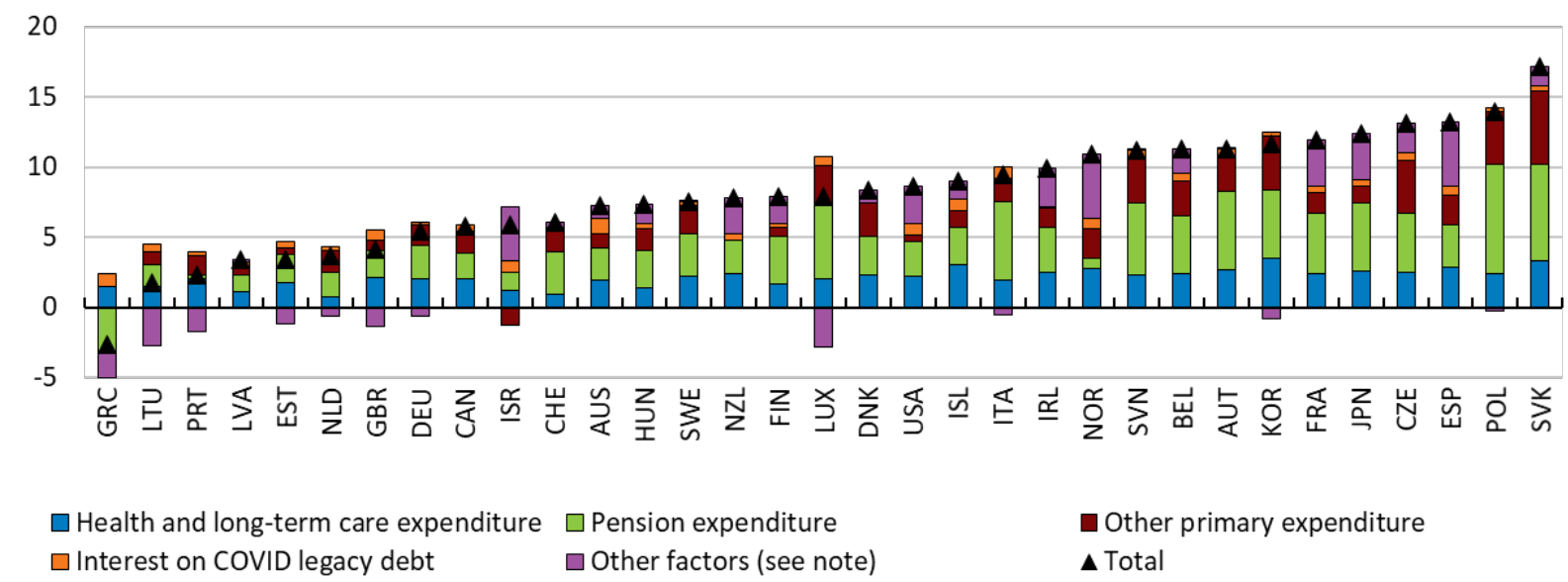

Note: The chart shows how the ratio of structural primary revenue to GDP must evolve between 2021 and 2060 to keep the gross debt-to-GDP ratio stable near its projected 2022 value over the projection period (which also implies a stable net debt-to-GDP ratio given the assumption that government financial assets remain stable as a share of GDP). The underlying projected growth rates, interest rates, etc., are from the baseline long-term scenario presented in Guillemette and Turner (2021 $\left.1_{[19]}\right)$. Expenditure on temporary support programmes during the COVID pandemic is assumed to decline to zero within a few years. The component "Interest on COVID legacy debt" approximates the permanent increase in interest payments due to the COVID-related increase in public debt between 2019 and 2022. The component "Other factors" mostly reflects the correction of any initial disequilibrium between the 2021 structural primary balance and the one that would stabilise the debt ratio.

Source: Guillemette and Turner (2021 $\left.{ }_{[19]}\right)$, "The Long Game: Fiscal Outlooks to 2060 Underline Need for Structural Reforms", OECD Economics Department Policy Papers, No. ${ }^{\circ} 29$, https://doi.org/10.1787/a112307e-en. 


\section{Figure 11. Potential future fiscal pressure to keep public debt ratio at current level with reforms to labour market and retirement policies}

Difference in fiscal pressure from the baseline scenario, in \% pts of potential GDP

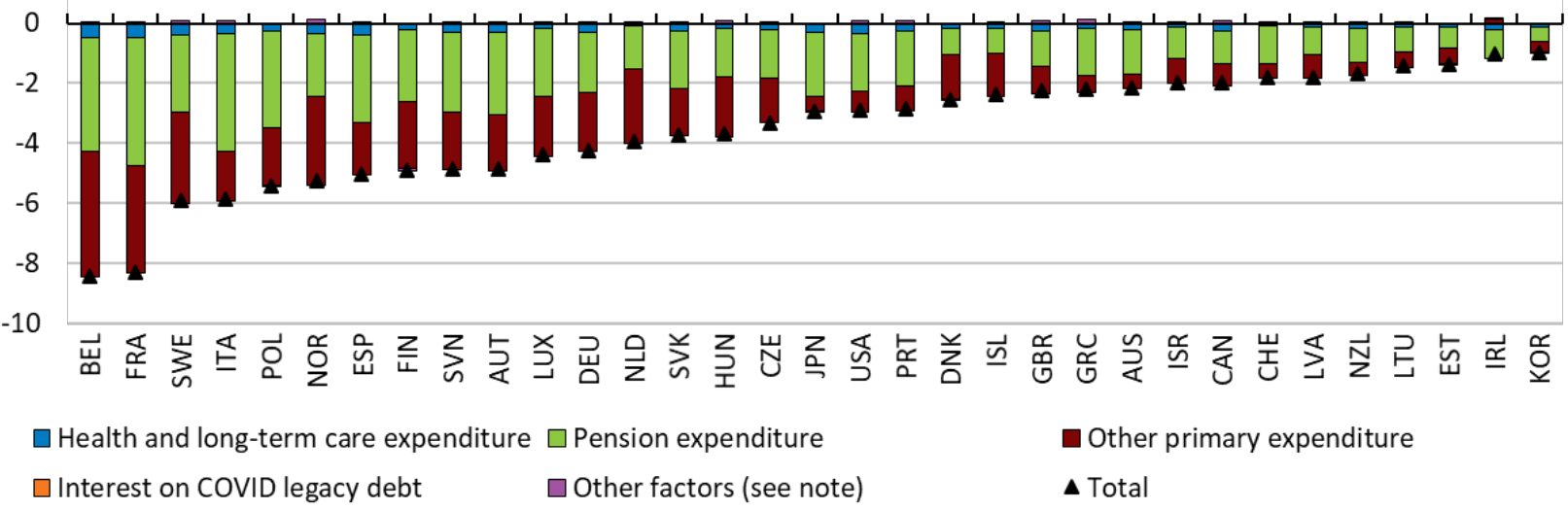

Note: The chart shows the difference in future fiscal pressures between a scenario with reforms to labour market and retirement policies, and the baseline scenario presented in Figure 10. The fiscal pressure metric measures how the ratio of structural primary revenue to GDP must evolve between 2021 and 2060 to keep the gross debt-to-GDP ratio stable near its projected 2022 value over the projection period (which also implies a stable net debt-to-GDP ratio given the assumption that government financial assets remain stable as a share of GDP). In the scenario with reforms, the underlying projected growth rates, interest rates, etc., are from an ambitious reform scenario combining labour market policy reforms with increases in average effective retirement ages, as described in Guillemette and Turner (2021 [19]). See also the note to Figure 10. Source: Guillemette and Turner (2021 [19]), "The Long Game: Fiscal Outlooks to 2060 Underline Need for Structural Reforms", OECD Economics Department Policy Papers, No. ${ }^{\circ 29}$, https://doi.org/10.1787/a112307e-en.

Box 3. The fiscal pressure indicator and the impact of structural reforms in the OECD long-term economic projections

The fiscal block of the OECD long-term model incorporates a fiscal rule which ensures that the structural primary balance adjusts so that the gross debt-to-GDP ratio eventually stabilises at its initial level (Guillemette and Turner, $\left.2021_{[19]}\right){ }^{1}$ Expenditure for different spending categories is projected, using simple reduced-form equations with either estimated (health) or calibrated (pension and other primary expenditure) coefficients. Structural revenue is then determined endogenously to satisfy the fiscal rule, and so their change provides a convenient summary indicator of future fiscal pressure which can be decomposed by the expenditure which generated it.

The long-term model projections are consistent with the latest short-term Economic Outlook projections, which includes the same determination of potential output. Output gaps at the end of the Economic Outlook horizon are assumed to close gradually and thereafter the projected growth rates are determined by projections of labour efficiency, employment, and physical capital, aggregated with a Cobb-Douglas production function. The nominal short-term interest rate depends mainly on potential growth and inflation. The interest rate on government debt converges to a weighted average of short-term and long-term interest rates (with weights based on the maturity structure). The long-term interest rate is a convolution of the future short-term rates plus a term premium, and additional risk premia linked to government debt levels. In the baseline scenario, the short-term real rate gradually converges toward the real potential growth rate (while typically starting below it) for most countries over the projection period. ${ }^{2}$

The latest stylised projections of expenditures until 2060 imply rising expenditure on: public health and long-term care (by 2.2 percentage points of GDP by 2060 in the median OECD country), resulting from 
population ageing and the rising relative price of services; public pensions (2.8 percentage points of GDP); and other primary expenditure categories (1 $1 / 2$ percentage points of GDP).

Long-term projections include an alternative scenario combining labour market policy reforms with increases in effective retirement ages (Guillemette and Turner, 2021 ${ }_{[19]}$ ). Regarding labour market reforms, each country is assumed to close by 2030 half of current gaps on a number of labour market policy indicators relative to the five best-performing OECD countries. This implies: 1 ) raising expenditure on active labour market policies (ALMP): 2) raising expenditure on family benefits in kind; 3 ) increasing maternity leave; and 4) lowering tax wedges for both single earners and couples. The magnitude of each specific reform depends, for each country and indicator, on gaps relative to best practices according to the latest available data. The implied additional expenditure on ALMP and family benefits are taken into account in the fiscal projections, but the other measures are assumed to require no additional spending or to be financed by less distortionary forms of taxation. Regarding retirement ages, governments are assumed to undertake policy measures so as to 1) close any initial shortfall between average effective and normal statutory retirement ages for both men and women; and 2) keep average effective retirement ages rising in the future at a rate equal to two thirds of projected gains in life expectancy if not already the case in the baseline scenario as per current legislation.

These reforms alleviate the fiscal pressures mostly through their impact on GDP per capita, which increases the denominator of the expenditure-to-GDP ratio. The impact of labour market reforms on GDP per capita and labour market outcomes is based on findings in Gal and Theising (2015[29]) and Égert and Gal $\left(2017_{[30]}\right)$. Increases in the retirement age boosts GDP per capita directly via the lengthening of working lives which increases the employment rate (it also reduces the fiscal pressure indicator by reducing pension expenditure directly).

1. See Guillemette and Turner (2021 $\left.{ }_{[19]}\right)$ for methodological details regarding the long-term expenditure projections. 2. This is not exactly the case for all countries: for example all euro area members face the same short-term rate but have different potential growth rates.

\subsection{Low growth hampers debt sustainability and the achievement of social objectives, calling for ambitious structural reforms and higher public investment}

Sustained low economic growth undermines tax revenues and thus makes it difficult to maintain public debt sustainability, addressing spending pressures and - more generally - improving populations' living standards. Productivity growth has decreased in the OECD countries over the past decades. Possible causes of this slowdown include, among other factors, disappointing gains from recent innovation waves, likely due to some extent to adjustment costs and insufficient diffusion of new technologies and innovations across firms (Andrews, Criscuolo and Gal, 2016 ${ }_{[311]}$ ); a decline in business dynamism (Calvino, Criscuolo and Verlhac, 2020 ${ }_{[32]}$ ); and a levelling of education attainments (Vollrath, 2019 ${ }_{[33]}$ ). The COVID-19 crisis could have positive effects on long-term productivity, for example by accelerating digitalisation, in particular the adoption of digital technologies by small and medium-sized businesses in services sectors. However, large recessions can have long-lasting and negative effects on productivity, including on the productivity of labour market entrants, as past crises have shown (Andrews et al., 2020[34]; von Wachter, 2020[35]; Furceri et al., 2021 [36]). Recent country evidence during the COVID-19 crisis suggests that some of those scarring effects could be mitigated by well-designed temporary job-retention schemes that support productivity-enhancing job reallocation (Andrews, Hambur and Bahar, 2021 [37]; Andrews, Charlton and Moore, 2021 $[38]$ ).

Higher economic growth would lower the debt-to-GDP ratio on its own. Towards this end, governments should implement ambitious structural reforms to boost potential growth (OECD, 2021 [39]). However, the experience from the past decade suggests that achieving higher growth quickly through structural reforms may be challenging without monetary and fiscal support. The sequencing of reforms will be particularly 
important to help the economic recovery gain traction, which implies starting with reforms which do not dampen aggregate demand in the near term and which work particularly well in periods of economic slack. Such reforms include lowering regulatory barriers to entry in professional services, or strengthening active labour market policies or family benefits to promote labour force participation. Enhancing activation and skills acquisition, as well as facilitating business entry and exit, will also improve labour market opportunities for all and help to foster productivity-enhancing reallocation.

Public investment can also support long-term growth if it allows for the accumulation of productive capital (Bom and Ligthart, 2014[40]). In addition, public investment in sectors that have large positive externalities for the rest of the economy could help to meet important social and environmental objectives, where market failures (among other factors) cause underinvestment by the private sector, and boost potential growth (Égert, Botev and Turner, 2019[41]; Hendren and Sprung-Keyser, 2020[42]). This applies in particular to public infrastructure investment in digital networks, transportation and energy, and in education, lifelong learning and health care. Public investment in these areas can improve productivity and be an important source of new jobs for displaced workers - provided adequate support for the transition, while helping to support demand as they usually have strong multipliers (Pain et al., 2018[43]). Current very low, and in some cases negative, bond yields make public investment particularly attractive. In this context, the initiatives in the European Union and the United States are welcome. ${ }^{17}$

Implementing public investment is hindered by challenges related to co-ordination across sectors, jurisdictions and governmental bodies; capacity to design and implement investment strategies; and framework conditions related to good practices in budgeting, procurement and regulatory quality. Governments can improve the governance framework for infrastructure spending by moving to OECD best-practice principles in this area (OECD, 2017[44]). High-quality public investment could be also facilitated by an increased use of special government investment entities, including ones that focus on innovation policies (Larrue, 2021 $\left.{ }_{[45]}\right)$.

\subsection{Growing inequality adds to fiscal challenges and requires changes in tax and spending policies}

Increasing inequality across different economic dimensions pose challenges for fiscal policy by adding pressures on government social programmes and by undermining growth and political stability. Income inequality has increased in many OECD countries over the past decades. The increase is partly due to automation and globalisation which have affected the distribution of market incomes, to uneven equality of opportunities and to less redistributive tax and transfer systems (Causa, Browne and Vindics, 2019[46]). In addition, wealth is increasingly concentrated at the very top of the distribution in some countries and social mobility is relatively low (Balestra and Tonkin, 2018[47]; OECD, 2018[48]). The COVID-19 crisis is likely to exacerbate income inequalities, at least in the short term, by disproportionately affecting certain vulnerable groups (OECD, 2020[49]; OECD, 2021 ${ }_{[50]}$ ). In addition, school closures during the crisis have probably had a relatively more negative impact on the education of children from disadvantaged backgrounds, potentially reducing their future employment opportunities (OECD, 2020[51]]).

Fiscal policy can address different types of inequality not only via a progressive tax and transfer system but also by promoting a greater equality of opportunities. The public finances have an important role to play in tackling inequalities by improving access to high-quality education, health care, affordable housing and lifelong training programmes (O'Reilly, 2018[52]). Increasing support to low-income households, including transfers and help with finding jobs, is likely to be an important component of policy options to

\footnotetext{
17 The EU Recovery and Resilience Facility funds are expected to boost government investment and increase public financial support for private investment in 2021-22, particularly in the green and digital transitions. The US administration has proposed the American Jobs Plan and the American Families Plan which include fiscal support for decarbonisation, infrastructure, research and development, job training, childcare and universal pre-school.
} 
tackle income inequality, in particular to adapt to the emergence of non-standard forms of work which have reduced the coverage of traditional social protection systems (OECD, 2019 [28]; OECD, 2020[53]). In-work benefits and credits have been effective at reducing inequality in recent decades, while boosting employment levels among target groups (Causa, Browne and Vindics, 2019 ${ }_{[46]}$ ). The progressivity of the tax system can also be supported by ensuring that, in particular, capital incomes are appropriately and efficiently taxed. For example, changes in inheritance taxation could partially address wealth inequalities while raising revenue, for instance by limiting generous and regressive tax exemptions (OECD, 2021 [54]).

Tax policy also needs to reflect ongoing challenges and progress in international co-operation on taxation. Broadening tax bases and improving compliance might be a way to increase tax collection and reduce the negative fiscal and social consequences of tax avoidance. For example, capital taxation may gain importance in future tax systems as the potential for more effective taxation of capital incomes has been enhanced by the implementation of the automatic exchange of taxpayer information, which has ensured that countries now have increased tools available to them to detect any offshore assets and income (O'Reilly, Parra Ramirez and Stemmer, 2019 ${ }_{[55]}$ ). Increasing the resources of tax administrations could boost tax revenues significantly and, likely, in a progressive way (Alstadsaeter, Johannesen and Zucman, 2019 $9_{[56] ;}$ Alstadsæter, Johannesen and Zucman, 2019 ${ }_{[57]}$; Sarin and Summers, 2019 ${ }_{[58]}$; Londoño-Vélez and Ávila-Mahecha, 2021 [59]).

\subsection{Accelerating digitalisation creates opportunities but also challenges for public finances}

The digitalisation of the economy has been ongoing for several decades and is being accelerated by the COVID-19 crisis. While offering opportunities to enhance productivity, long-term growth, efficiency of public administration and tax compliance, ${ }^{18}$ with subsequent benefits for tax revenues and debt sustainability, digitalisation also poses challenges for public finances. Specific skills are crucial for benefiting from a digitalised world, which necessitates adequate provision of education and lifelong learning services, and investment in infrastructure, possibly requiring higher public spending (Gal et al., 2019 [60]; OECD, 2019 [61]; OECD, 2019[62]; OECD, 2019[63] $)$. For instance, school closures during the pandemic have highlighted remaining gaps in access, quality and use of digital resources for learning by, and teaching of, children and students, calling for means to level up digitalisation take-up (OECD, 2021 [64]). In addition, improving broadband connectivity, helping firms to develop online business models, enhancing acquisition of digital skills, and ensuring secure online payments and data privacy, are all areas of reform that would help to foster the digital transformation and ensure that poorer households, small firms and remote regions also have access and can benefit. Moreover, digitalisation affects workers through the rise of the "gig economy" which offers flexible business models but can result in tax distortions and gaps in social protection systems (OECD, 2018[65]; Milanez and Bratta, 2019[66]).

Specific features of digital markets that are also conducive to a "winner-takes-most" dynamic can contribute to the concentration of activities among a small number of highly profitable and intangible-intensive "superstar" firms, posing challenges for competition policy and corporate taxation (OECD, 2018[67]). The "Statement on a Two-Pillar Solution to Address the Tax Challenges Arising from the Digitalisation of the Economy", which has been agreed to by 136 jurisdictions as of 8 October 2021, marks a significant development in multilateral efforts to reform the international tax rules and ensure that they are "fit-forpurpose" in the modern economy, by addressing the tax challenges arising from the digitalisation of the economy (OECD, 2021 $\left.{ }_{[68]}\right)$. Under the two-pillar package, Pillar One seeks to ensure a fairer distribution of taxing rights among countries with respect to the largest and most profitable multinational enterprises (MNEs), including digital companies. It would re-allocate some taxing rights over MNEs from their home countries to the markets where they have business activities and earn profits, regardless of whether firms

\footnotetext{
${ }^{18}$ For example, big data are increasingly used by tax administrations to combat tax fraud (OECD, 2021 [187]).
} 
have a physical presence there. Pillar Two seeks to put a floor on competition over corporate income tax, through the introduction of a global minimum corporate tax rate that countries can use to protect their tax bases.

\subsection{Climate change and policies to mitigate and adapt to it will have profound implications for public finances}

Climate change risks dire social and economic consequences. While the precise nature of the ensuing negative effects are highly uncertain, frequent extreme climate events (e.g. climate catastrophes) have the potential to reduce economic growth and increase its volatility, with destructions of physical infrastructure, disruptions to production and population migrations, and to undermine political stability (OECD/The World Bank, 2019[69]; Office for Budget Responsibility, 2021 $\left.{ }_{[70]}\right)$. Such conditions could threaten fiscal sustainability as they would require, among other things, extra spending in response to climate events, on social benefits and health care, and would erode certain tax bases (Barrage, 2020[71]; Baur, Bruchez and Nicol, 2021 [72]; CBO, 2021 [73]).

Mitigating climate change and associated negative risks calls for urgent action across a wide range of policy areas, with tax and government spending playing a key role (OECD, 2021 ${ }_{[3]}$ ). A crucial priority for the coming decades is to reduce carbon emissions, with an objective of net zero emissions by the middle of the century. The transition to a low-carbon economy could offer new opportunities for growth, improvements in the quality of life, new sources of government revenues, and could bring a range of significant longer-term benefits $\left(\mathrm{OECD}, 2016_{[74]}\right.$; IEA, 2020[75]). However, it may also create disruptions to current business models and require substantial financial resources during the transition.

- Effective pricing of harmful emissions and polluting activities, through either taxes or cap-and-trade systems of emissions permits, is needed. Ambitious emissions pricing could raise large amounts of revenue in the short and medium terms, however the resulting lower consumption of fossil fuels, particularly in the transport sector, could also reduce related tax revenues in the medium term (Marten and van Dender, 2019 $[76]$; Office for Budget Responsibility, 2021 $\left.{ }_{[70]}\right) .{ }^{19}$ Fossil fuel subsidies also continue to distort price signals and weigh on public budgets, and should be phased out (OECD/IEA, 2021 $\left.1_{[77]}\right)$.

- Fiscal policy could directly support environmental sustainability through fiscal incentives to R\&D, direct grants, public research, and support for early-stage development, as well as new infrastructure investment projects, including expanding and modernising electricity grids, renewables capacity and transport network (OECD, 2011[78]; Hepburn, Pless and Popp, 2018[79]; OECD, 2021[3]).

- All such steps would need to be accompanied by a package of compensating measures to mitigate the adverse impact on poorer households, affected regions and small businesses, and to help displaced workers acquire new skills and take advantage of new employment opportunities, and consequently ensure public acceptance (Botta, 2019[80]; OECD, 2021 [39]). ${ }^{20}$ They will also require international co-ordination due to the potential for emissions leakages (e.g. through supply chains) and the implications of tax and subsidies for countries' competitiveness.

\footnotetext{
${ }^{19}$ For instance, the fall in revenues from taxes on motoring is expected to be the single largest cost of the transition in the United Kingdom (Office for Budget Responsibility, 2021[70]).

${ }^{20}$ Canadian experience offers an example of gaining public acceptance for climate related taxation. The Government of British Columbia (BC) introduced a carbon tax in 2008. While there was some backlash towards this tax, it has remained an important element of environmental and fiscal policy in BC. Possible reasons for this include increased familiarity with the tax; a range of support measures, including aid to firms, income tax cuts and targeted tax rebates and financial transfers; and the importance of the tax revenue for the provincial budget (Harrison, 2013 [186]).
} 
Efforts to significantly reduce climate change need to be complemented with measures to build resilience to climate-change-induced impacts. Even if global average temperature increases are limited to below $2^{\circ} \mathrm{C}$, there will still be serious climate impacts. This implies that mitigation and adaptation are complementary, and adaptation can reduce the earliest costs of climate change (OECD, 2015[81]). Measures to adapt to climate change will be indispensable to not only safeguard lives and secure livelihoods, but also to contain rising inequalities exacerbated by a changing climate (Gamper and Lamhauge, 2021 [82]). Such conditions will require, among other things, protective measures for vulnerable communities and infrastructure. However, climate adaptation measures should not undermine investment in mitigation as this would ultimately worsen the medium to long-term impact of climate change (Gamper and Rambali, 2021 [83]).

\subsection{Health care spending may add to fiscal pressures}

Considerable long-term spending pressures on health care due to population ageing (Figure 10) is likely to be aggravated by the greater awareness of catastrophic economic and social implications of pandemics. Given the experience with the COVID-19 pandemic, politicians and voters may wish to enhance the ability of health systems to identify and prevent the materialisation of such pandemics, and to improve resilience to such risks should they materialise. This may require new government expenditure for example to build reserve healthcare capacity, and buffers for essential medical goods and equipment. In addition, governments will have a role to play in supporting basic research and development and public health campaigns.

\subsection{Fiscal policy may need to play a larger role in stabilising business cycles}

With sustained low inflation and low neutral interest rates driven by structural factors, conventional monetary policy will likely be constrained by an effective lower bound, at least in the near future (Bean et al., 2015[84]; Rachel and Smith, 2015[85]; Gourinchas and Rey, 2019[86]; Rachel and Summers, 2019[87]). While central banks have tools to implement unconventional monetary policy such as asset purchases or forward guidance (Ball et al., 2016[88]), their marginal effectiveness is likely to be limited. For instance, quantitative easing is not going to ease financial conditions by much if short and long-term interest rates are already low (Schnabel, $2021_{[89]}$ ). A limited scope to boost demand during downturns by monetary policy on its own will in turn put pressure on fiscal policy. This will be particularly important if large hysteresis effects - where temporary demand shortfalls lead to persistent output losses - were to be expected (Fatás and Summers, 2018[90]; Cerra, Fatás and Saxena, 2020[91]).

There are two additional arguments for a more prominent demand management role of fiscal policy in the context of low interest rates. First, fiscal multipliers of government spending appear significantly larger at the zero lower bound (ZLB) (Christiano, Eichenbaum and Rebelo, 2011[92]; Miyamoto, Nguyen and Sergeyev, 2018[93]; Ramey, 2019[94]; Klein and Winkler, 2021[95]). ${ }^{21}$ Recent literature suggests that cumulative public expenditure multipliers are 1.5 or above in such an environment so that extra public spending does not ultimately add to the expenditure-to-GDP ratio, and improves sustainability. This effect is also likely to be larger in recessions although the evidence of an asymmetry linked to the cycle is less clear-cut (Goode, Liu and Nguyen, 2021 [96]; Klein and Winkler, 2021[95]; Ramey, 2019[94]). Second, if low real interest rates are driven by excess desired global savings (Bernanke, 2015[97]), fiscal policy is more likely to have positive externalities across countries, while monetary expansions or competitiveness policies (which increase "exported savings") could be beggar-thy-neighbour (Eggertsson, Mehrotra and Summers, 2016[98]; Eggertsson et al., 2016[99]).

In principle, fiscal stabilisation of demand can be achieved via the reinforcement of automatic stabilisers or stronger discretionary actions. In general, automatic stabilisers are better to accommodate temporary

21 The "zero lower bound" refers more generally to the existence of a floor on nominal interest rates and could be more precisely described as an "effective lower bound" (ELB) which is not necessarily zero. 
negative shocks than discretionary fiscal stimulus (Sutherland et al., 2010 [100]; Blanchard and Summers, $\left.2020_{[101]}\right)$. They are by construction temporary and do not affect the structural fiscal policy stance, reducing chances of a pro-cyclical fiscal policy. They are also timely as they do not suffer from the information, decision, design and implementation lags as could be the case with discretionary policy. ${ }^{22}$ Still, discretionary fiscal actions can be needed if automatic stabilisers are small or not very effective, or when the negative shock is exceptionally large. Recognising challenges with measuring the discretionary fiscal policy stance and its correlation with the cycle, there is some evidence that discretionary fiscal policy has often been pro-cyclical in the past (Annex D).

The first option to strengthen the role of fiscal policy in demand stabilisation in downturns is thus to boost existing automatic stabilisers. While the operation of automatic fiscal stabilisers usually is not the main and direct motivation for reforms of tax and benefit systems, such reforms can sometimes support their effectiveness. For example, making personal income taxation more progressive and changing the structure of taxes towards highly elastic revenues that affect household disposable income directly could boost automatic fiscal stabilisation, although additional taxation of elastic bases could generate efficiency losses (Maravalle and Rawdanowicz, 2020[75]). ${ }^{23}$ Beyond purely automatic fiscal stabilisers, short-time work compensation schemes with built-in exit mechanisms and well-designed active labour market policies could help stabilise the economy after a negative shock. Such policies have been used during the last two global recessions. ${ }^{24}$

However, existing automatic stabilisers may be too narrow to achieve the desired demand stabilisation (Blanchard and Summers, 2020[101]; IMF, 2020[102]). In addition, by construction they will usually fail to take into account the inherent asymmetry of the ZLB (Eichenbaum, 2019 $9_{[103]}$ ). In this context, new automatic stabilisers whose intensity is state-dependent have been considered. ${ }^{25}$ For instance, they could involve direct lump-sum transfers to individuals when the unemployment rate increases above a certain threshold, and be scaled down/eliminated depending on the decline in the unemployment rate (Sahm, 2019[104]).

Such rules come with a risk of increasing deficits and debt compared with a situation where demand is stabilised by monetary policy. For example, the "Sahm rule" under a constrained monetary policy could increase debt and deficits after four years compared with the scenario with unconstrained monetary accommodation. Still, strong multipliers when monetary policy is constrained also suggest that the "Sahm rule" would improve public finances in these circumstances, compared with a scenario without fiscal support (IMF, 2020[102]). To limit budget burden of direct lump-sum transfers to individuals during recessions, an effective rainy-day fund could be established, financed by higher taxation or smaller transfers in good times (Sahm, 2019[104]).

\footnotetext{
22 However, the experience of advanced economies during the GFC and COVID-19 crisis demonstrates that discretionary fiscal responses can be quick (IMF, 2013[190]).

${ }^{23}$ For example, personal income taxes are usually more elastic to income than social security contributions, although this specific swap could affect negatively the link between contributions and entitlements.

24 One lesson from the global financial crisis was that having in place - and ready to be activated - a programme to facilitate work-time sharing among employees helped to mitigate the labour market consequences of the recession as they could be deployed quickly and on a large scale. As a result, many countries seemed better prepared at the time of the pandemic to use similar job-retention schemes.

25 Such stabilisers are not completely new, as some business-cycle-contingent rules for the generosity of unemployment benefits already exist, for instance in Canada and the United States.
} 


\section{Effective fiscal frameworks for resilient public finances}

Challenges with implementing optimal fiscal policy, high public debt, and growing current and future demands on fiscal policy (see previous section) all call for implementing effective fiscal frameworks. The latter refers to processes and institutions, including budgetary procedures, fiscal rules and independent fiscal institutions, that affect policy decisions and ultimately budgetary and debt outcomes.

Effective fiscal frameworks should help ensure that fiscal policy is sufficiently responsive to contingencies and that required state-contingent policies are implemented in a credible way with broad political and social support. ${ }^{26}$ In particular, fiscal frameworks should help fiscal policy respond symmetrically to the business cycle, and minimise deficit biases and forecast optimism by changing the incentives of political actors involved in the preparation of the budget. They should also encourage resilience to future uncertainties, for instance by well-chosen indexation rules (Orszag, Rubin and Stiglitz, 2021[21]). Finally, they should foster accountability and transparency in the budgetary process to ensure that governments' tax and spending choices are viewed as legitimate and equitable by the broader public and thus encourage political sustainability (Alt, Lassen and Wehner, 2014[105]; OECD, 2017[106]).

The trust-building fundamentals of fiscal frameworks include high transparency, independent assessments of longer-term fiscal strategies, and public debates. Independent fiscal institutions (IFIs) with a broad mandate can contribute to these elements, possibly in combination with fiscal rules which strengthen political commitment. Strong fiscal frameworks can in turn increase credibility with financial markets, thus ensuring the smooth functioning of government bond markets during economic downturns and ultimately enabling governments to stabilise the economy.

At present, fiscal frameworks vary widely across the OECD countries. The empirical literature has focused on four main elements that often generate synergies: fiscal rules, IFIs, budget transparency and mediumterm expenditure frameworks. In addition, spending reviews are increasingly being used across OECD countries as they help to create fiscal space and to prioritise spending (Tryggvadottir, 2021 forthcoming $[107])$.

This section briefly introduces the political economy factors that provide the rationale for strong budgetary institutions and then discusses fiscal rules and IFIs. Box 4 provides information on the two other aspects of fiscal frameworks. The section builds largely on OECD research, to indicate best practices on how to ensure effective and resilient fiscal frameworks to help address the numerous policy challenges as discussed below. Identifying empirically positive links between a specific element of fiscal frameworks and a specific fiscal outcome is difficult. This relates to challenges with singling out the impact of one particular feature given the coexistence of several rules, IFI and budget procedures; defining fiscal outcomes and accounting for macroeconomic influences; and clearly establishing causality. Consequently, specific features could help but do not necessarily guarantee positive fiscal outcomes, depending on the other characteristics of the framework, and various fiscal framework models could work equally well depending on country-specific circumstances. One important consideration is that the framework as a whole needs to work well, which depends on the degree of integration and co-ordination of the various elements. For example, fiscal rules work better when other institutions ensure transparency and IFls are better able to scrutinise fiscal performance when the government clearly defines medium-term objectives.

\footnotetext{
26 This objective can be motivated in part by the theoretical literature of fiscal reaction functions, suggesting that a primary balance which is sufficiently "responsive" to debt levels guarantees solvent public finances (Bohn, 1998[11]; Lorenzoni and Werning, 2019[170]).
} 


\section{Box 4. The role of medium-term expenditure frameworks and budgetary transparency}

Medium-term expenditure frameworks (MTEFs) integrate fiscal policy and budgeting over a multi-year horizon, including fiscal objectives and forward planning of multi-year budgets. There is a large body of evidence suggesting that they contribute to sound fiscal policies. They help improve the ambition of fiscal plans, their implementation and ultimately the fiscal balance (Beetsma, Giuliodori and Wierts, 2009[108]; Vlaicu et al., 2014[109]). Additionally, there are synergies between fiscal rules, independent fiscal institutions and an effective medium-term budgeting framework, which can strengthen their effectiveness at the national and EU level (Nerlich and Reuter, 2013[110]).

Budgetary transparency can enhance fiscal discipline and reduce the scope for electoral fiscal cycles. Budgetary disclosure and participation is consistently associated with improved budget quality, and governance and development outcomes (de Renzio and Wehner, 2017[111]). Transparency reduces electoral budget cycles and is associated with lower public deficits and debt (Alt and Lassen, 2006[112]; Alt and Lassen, 2006[113]). Fiscal transparency can also improve budget credibility by making it harder to manipulate budget forecasts (EIBerry and Goeminne, 2021[114]).

\subsection{Political incentives and social constraints tend to weaken fiscal prudence}

Governments are subject to a series of political incentives and social constraints which have often contributed to budget deficits - the so-called deficit bias (Error! Not a valid bookmark self-reference.). Deficit biases can stem from the common-pool problem where public spending, benefiting specific groups, is financed by the whole society. Consequently, those enjoying the marginal benefit from an extra unit spent on a project are not necessarily those bearing the marginal cost of funding it, and spending ends up being above the level that equates the social marginal benefit and the social cost of funding. Such behaviour is more likely with high political polarisation and fragmentation, with frequent political turnover, or when policy co-ordination is more complex. ${ }^{27}$ Moreover, electoral cycles can contribute to less prudent fiscal policies as a government may be inclined to engage in fiscal expansion (e.g. by spending on investment or social transfers) before elections to increase chances of being re-elected. ${ }^{28}$ Such effects could be amplified by fiscal illusion: voters overestimate the benefits of current spending and underestimate the future tax burden that will be needed to finance current expenditures, or how this tax burden will be shared among generations.

Political incentives and social constraints can lead to public underinvestment to the detriment of future output growth and quality of public services. Cutting public investment is politically easier than reducing other expenditures or social benefits. In the latter case, effects of the cuts are felt by the electorate immediately, while - in the former case - they involve only forgone future benefits. Indeed, public investment was the principal casualty of fiscal consolidations in the past and governments tended to cut investment spending during economic downturns (Blöchliger, Song and Sutherland, 2012[115]; Bamba, Combes and Minea, 2020[116]).

\footnotetext{
${ }^{27}$ For example, larger deficits are found in countries with more ministers, with greater ideological polarisation in the executive branch, and with a proportional (as opposed to majoritarian) election system (Woo, 2003[121]; Persson and Tabellini, 2004 [122]; Crivelli et al., 2016[123]).

${ }^{28}$ Empirical evidence about the importance of the electoral cycle is mixed but some studies find that they matter for government budgets as tax-based austerity carries large electoral costs (Alesina et al., 2021[185]). In view of these costs, incumbent governments have little interest in introducing austerity measures right before elections.
} 
Table 1. Political economy biases affecting fiscal outcomes

\begin{tabular}{|c|c|c|}
\hline Issue & Mechanism & Effect \\
\hline Fiscal illusion & $\begin{array}{l}\text { Lack of information/transparency. Voters overestimate the benefits of public spending, } \\
\text { either because their knowledge about the tax system and the economy is limited or } \\
\text { because politicians hide relevant information (von Hagen and Harden, } 1995_{[117]} \text {; Dollery } \\
\left.\text { and Worthington, 1996[118]; Mourão, 2008[119]; Dell'Anno and Dollery, 2013 }{ }_{[120]}\right)\end{array}$ & Deficit bias \\
\hline $\begin{array}{l}\text { Common-pool } \\
\text { problem }\end{array}$ & $\begin{array}{l}\text { Negative externalities. Many individual actors are involved in spending decisions but no } \\
\text { one fully internalises the costs, which leads to a deficit bias (Woo, 2003[121]; Persson } \\
\text { and Tabellini, } 2004_{[122]} \text {; Crivelli et al., 2016 }{ }_{[123])} \text {. A variation of this issue can occur in } \\
\text { monetary unions and federations where constituent units retain budgetary sovereignty. }\end{array}$ & $\begin{array}{l}\text { Deficit bias, pro-cyclical fiscal } \\
\text { policy }\end{array}$ \\
\hline $\begin{array}{l}\text { Electoral } \\
\text { competition }\end{array}$ & $\begin{array}{l}\text { Lack of information/transparency. Governments attune their fiscal policy to electoral } \\
\text { cycles instead of business cycles. They avoid austerity or increase spending before } \\
\text { elections, either to signal competence by providing more public goods or to bind the } \\
\text { hands of future governments (Persson and Svensson, } 1989_{[124]} \text {; Alesina and Tabellini, } \\
\left.1990_{[125] ;} \text { Pettersson-Lidbom, } 2001_{[126]}\right) \text {. }\end{array}$ & $\begin{array}{l}\text { Deficit bias, pro-cyclical fiscal } \\
\text { policy }\end{array}$ \\
\hline $\begin{array}{l}\text { Unequal } \\
\text { representation } \\
\text { / present bias }\end{array}$ & $\begin{array}{l}\text { Because of present bias and because future voters are not involved in political } \\
\text { decisions, spending tends to bring forward resources by relying on debt, or to spend on } \\
\text { current consumption instead of investing (Musgrave, 1988 } 8_{[127]} \text {; Coombes and Dollery, } \\
\text { 2002[128]; Jackson and Yariv, 2014[129]. }\end{array}$ & $\begin{array}{l}\text { Deficit bias, low public } \\
\text { investment }\end{array}$ \\
\hline Low trust & $\begin{array}{l}\text { Voters demand higher spending or lower taxes during an economic boom because they } \\
\text { do not trust the government to make good use of the additional resources available } \\
\text { (Alesina, Campante and Tabellini, } 2008_{[130]} \text {. }\end{array}$ & $\begin{array}{l}\text { Pro-cyclical fiscal policy, low } \\
\text { public investment }\end{array}$ \\
\hline
\end{tabular}

Source: Authors' compilation.

\subsection{Fiscal rules: Theoretical benefits and practical challenges}

Fiscal rules can improve fiscal policy by addressing several of the issues discussed above. In particular, they force the government to be explicit about fiscal indicators and provide a frame of reference for assessing fiscal performance, thus increasing transparency and reducing fiscal illusion. They can help against common-pool problems by defining an upper limit for deficits or expenditure, forcing the actors involved in the budget negotiations to pursue their interests by bargaining for a bigger share of a fixed amount. If rules are formulated with reference to the business cycle, they can restrict fiscal expansion at times that are inappropriate from a stabilisation perspective, mitigating electoral cycles. Indeed, discretionary stimulus during upswings has been quite common and relatively sizeable - on average across countries and time around 1\% of potential GDP (Figure 12; Figure A D.2 in Annex D). Moreover, fiscal rules have the potential to reduce present bias in fiscal policymaking. They can ensure that debt is not increased at the expense of future generations while explicitly protecting certain spending categories like public investment which improve future living standards (Ardanaz et al., 2021 [131]). 


\section{Figure 12. Frequency of discretionary fiscal easing during cyclical upswings}

As a per cent of cyclical upswing years in the country-specific sample

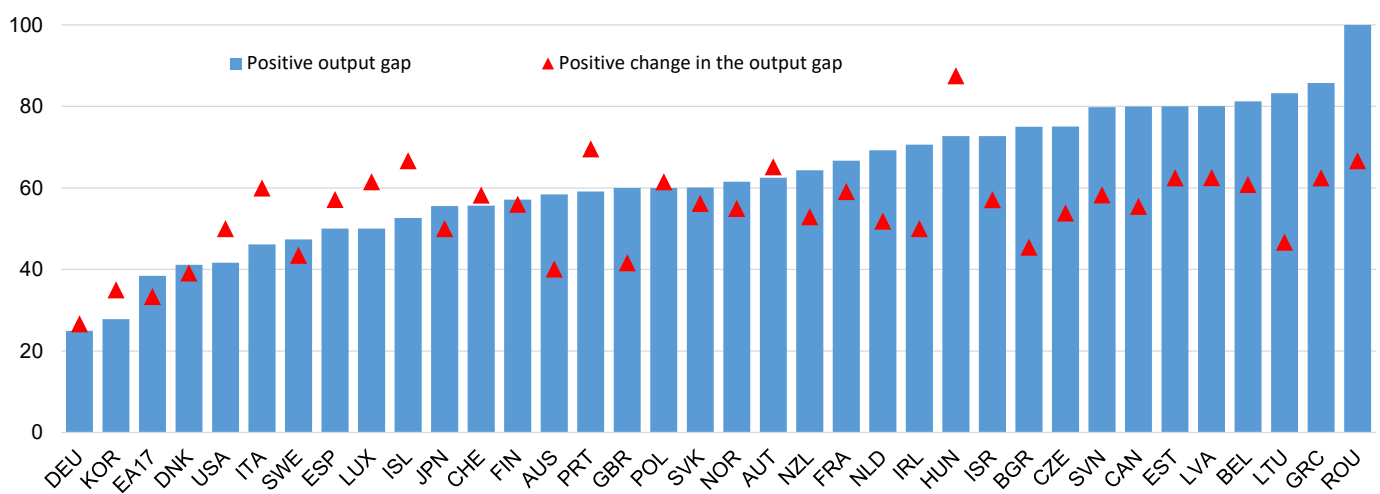

Note: Discretionary fiscal easing is defined as a negative change in the ratio of the underlying primary balance to potential GDP. See Annex D for more details.

Source: OECD Economic Outlook No 109 database; and authors' calculations.

In practice, fiscal rules involve a trade-off between simplicity and credibility. Simple rules are easy to understand and monitor, helping to enforce compliance and to hold governments accountable. However, simple rules (such as deficit or debt limits) are likely to prescribe suboptimal policy by being either too strict or too lax in a given situation (Wyplosz, 2012[132]; Portes and Wren-Lewis, 2015[133]). If they are observed, they can lead to pro-cyclical fiscal policies, for example by restricting the stabilisation role of fiscal policy during recessions. If they are broken, they lose their credibility. Reducing fiscal pro-cyclicality and allowing governments to react flexibly to emerging contingencies without losing credibility requires complex rules. But such rules are harder to monitor and easier to avoid thanks to loopholes, making them less credible (Wyplosz, 2012[132]).

Credibility and flexibility are also related to the ease of changing the rules. In several EU countries, fiscal rules have constitutional rank. That renders them tamper-proof and more binding (Asatryan, Castellón and Stratmann, 2018[134] ), but also hard to adapt to structural changes in the macroeconomic environment. The latter is especially disadvantageous if the rules are detailed and therefore likely to include elements that require regular updating. By contrast, rules that are based on ordinary legislation risk being altered so frequently that they do no longer constitute a credible commitment.

Fiscal rules are widespread and their design varies considerably across OECD countries (Box 5). While compliance with rules is often low (Eyraud et al., 2018[135]), they can still affect fiscal policy by acting as a benchmark (Reuter, $2015_{[136]}$ ). However, this also means that rules can act as targets rather than limits. In some countries with large deficits, they have prompted governments to tighten fiscal policy, and in a few countries with a budget surplus they have led them to ease the fiscal stance (Caselli, Stoehlker and Wingender, $\left.2020_{[137]}\right)$. A rule's effectiveness is shaped by its stringency and the ability of institutions to enforce the rule. Under an effective administration, strong fiscal rules are associated with more counter-cyclical fiscal policy (Bergman and Hutchison, 2015[138]). Higher stringency is also associated with better compliance with targets such as lower deficits and spending (Fall et al., 2015 [139]). A meta-analysis of the literature underlines the importance of accounting for endogeneity (Heinemann, Moessinger and Yeter, 2018[140]): it is possible that fiscal rules and a restrictive fiscal policy are both caused by a political consensus in favour of low debt and deficits. However, recent studies that address this concern through an instrumental variable approach (Caselli and Reynaud, 2020[141]) or a synthetic difference-in-differences approach (Caselli, Stoehlker and Wingender, 2020[137]) confirm that rules are associated with a better budget balance. 


\section{Box 5. Characteristics of fiscal rules differ across OECD countries}

In contrast to more general fiscal policy principles or objectives, fiscal rules impose numerical limits on the budgetary aggregates (OECD, 2019[142]). A 2018 OECD survey shows that all OECD members have one or several such fiscal rules in place at the national level, even though they take on a variety of forms and target diverse indicators. Only Australia, Canada, New Zealand and Norway do not have numerical rules enshrined in legislation (OECD, 2019[142]).

In general, there are four categories of fiscal rules: rules targeting the budget balance, debt, expenditure, and revenue (Figure 13). Two-thirds of OECD countries have legislated rules that target the structural budget balance. Rules about the nominal deficit are almost equally common. By contrast, less than a fifth of OECD members have rules addressing the primary balance, and "golden rules", that aim at protecting investment spending, are rare. The latter reflects the weakness of such rule stemming from incentive to use "creative" accounting to record current spending as investment (Koen and van den Noord, 2005[143]; Wyplosz, 2012[132]]. When it comes to rules about debt, ceilings and level targets are the most widely used, but annual debt reduction targets are also common. About half the OECD countries limit the growth or level of public spending. Revenue-based rules are less common: only about one in three OECD countries limits how windfall profits can be used, and even fewer put a limit on overall revenue.

At the subnational level, fiscal rules are only slightly less common, and their design is similar in principle, though golden rules are relatively more common (Ter-Minassian, 2007[144]; Eyraud et al., 2020[145]). In addition, members of the euro area are also subject to supranational fiscal rules defining limits on headline and structural deficits as well as a debt limit of $60 \%$ of GDP and debt reduction targets for those countries in excess of the limit (Bilbiie, Monacelli and Perotti, 2021 ${ }_{[146]}$ ).

\section{Figure 13. National fiscal rules are diverse and widespread across the OECD countries}

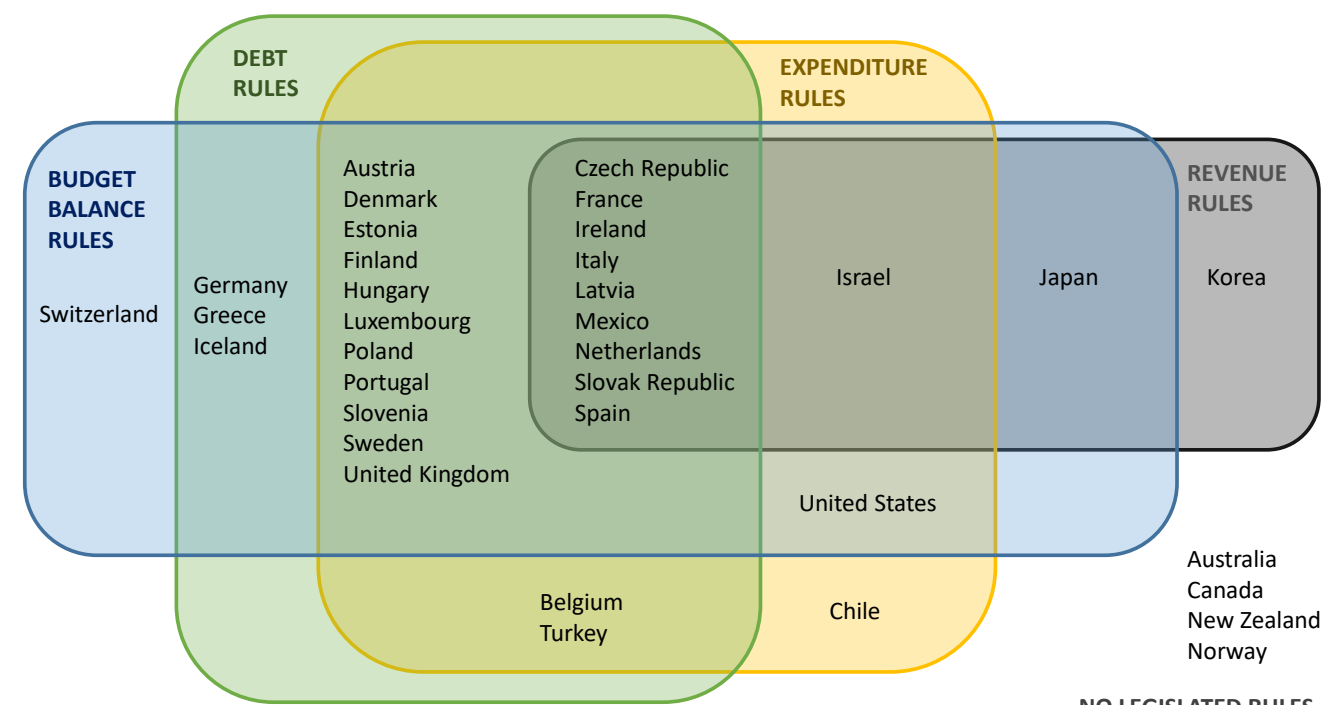

Note: EU member states are also subject to fiscal rules at the European level. Moreover, euro area member states and Denmark are bound by the provisions of the European Fiscal Compact.

Source: OECD (2019), Budgeting and Public Expenditures in OECD Countries 2019, OECD Publishing, Paris, https://dx.doi.org/10.1787/9789264307957-en; OECD Secretariat. 
No single rule design is equally suitable for all countries since each comes with advantages and drawbacks (Table 2). The choice of rule should depend on institutional characteristics and a careful country-specific analysis of weaknesses in the budgetary and political process. For instance, countries that prioritise clear communication vis-à-vis markets or citizens might find simple budget balance rules useful. In countries where the tax burden is already high, a revenue rule might be more adequate. Countries that achieve very high budgetary accountability through institutions and the political process might want to preserve full flexibility and not to adopt any rules at all.

Fiscal rules work better if it is costly for policymakers to break them. Rule-breaking typically results in tangible costs if it is sanctioned by investors in sovereign bonds, who can demand higher interest rates on government debt, or voters, who can vote governments out of office. Both need reliable information on which they can base their judgement. This requires a high degree of budgetary transparency, which can be fostered by strong IFIs (Alt and Lassen, 2006[113]; Alt, Lassen and Wehner, 2014[105]). As the next subsection shows, the literature suggests that the additional transparency and accountability IFIs provide can also help resolve trade-offs between flexibility and enforceability, and improve governments' credibility vis-à-vis stakeholders and markets.

\section{Table 2. Advantages and drawbacks of existing fiscal rules}

\begin{tabular}{|c|c|c|c|}
\hline & Promotion of fiscal discipline & Impact on stabilisation policies & Risks and side effects \\
\hline $\begin{array}{l}\text { Budget } \\
\text { balance rules }\end{array}$ & $\begin{array}{l}\text { Numerical budget balance rules } \\
\text { seem to have a positive impact on } \\
\text { budgetary outcomes (i.e. higher } \\
\text { surpluses or lower deficits) and give a } \\
\text { concrete benchmark upon which to } \\
\text { judge the fiscal stance. }\end{array}$ & $\begin{array}{l}\text { Strict budget balance rules fail to } \\
\text { provide enough flexibility to pursue } \\
\text { a counter-cyclical fiscal policy. } \\
\text { They tend to induce pro-cyclicality } \\
\text { that can be reinforced by weak co- } \\
\text { ordination between different } \\
\text { government levels. }\end{array}$ & $\begin{array}{l}\text { They can induce governments under } \\
\text { fiscal consolidation pressures to rely } \\
\text { excessively on cuts to } \\
\text { growth-enhancing, but politically less } \\
\text { sensitive, expenditure such as public } \\
\text { investment. To counter such adverse } \\
\text { effects, it is often proposed to exclude } \\
\text { investment and focus on the current } \\
\text { balance (Golden rule). }\end{array}$ \\
\hline $\begin{array}{l}\text { Structural } \\
\text { balance rules }\end{array}$ & $\begin{array}{l}\text { In principle, structural balance rules } \\
\text { underpin fiscal discipline. As they set } \\
\text { a target for the evolution of a core } \\
\text { variable, which is purged of cyclical } \\
\text { effects, they define the space for } \\
\text { discretionary policy. }\end{array}$ & $\begin{array}{l}\text { Structural or cyclically-adjusted } \\
\text { balance rules provide some } \\
\text { flexibility as they allow the } \\
\text { automatic stabilisers to operate. }\end{array}$ & $\begin{array}{l}\text { These rules are vulnerable to } \\
\text { uncertainties about the measurement of } \\
\text { the output gap, which renders real-time } \\
\text { monitoring difficult. A structural deficit } \\
\text { rule can be misleading if the output gap } \\
\text { and potential growth estimates are too } \\
\text { optimistic or too pessimistic. }\end{array}$ \\
\hline $\begin{array}{l}\text { Expenditure } \\
\text { rules }\end{array}$ & $\begin{array}{l}\text { Expenditure rules enhance fiscal } \\
\text { discipline thanks to better } \\
\text { accountability and higher } \\
\text { transparency in the budget process. } \\
\text { They allow for better control of } \\
\text { primary spending. }\end{array}$ & $\begin{array}{l}\text { A well-designed spending rule } \\
\text { should not prevent the automatic } \\
\text { stabilisers from operating. Also, } \\
\text { spending rules can limit pro-cyclical } \\
\text { spending in the presence of } \\
\text { revenue windfalls in good times. }\end{array}$ & $\begin{array}{l}\text { Spending rules have the same } \\
\text { drawbacks as budget balance rules } \\
\text { regarding the quality of spending or } \\
\text { cuts, in particular in difficult times. They } \\
\text { also can induce the use of tax } \\
\text { expenditures for various policy } \\
\text { objectives for which direct spending } \\
\text { might be better suited. }\end{array}$ \\
\hline Revenue rules & $\begin{array}{l}\text { Revenue rules can be useful in } \\
\text { limiting the tax burden. The impact on } \\
\text { deficit limitation is a by-product as } \\
\text { limitations on revenues should } \\
\text { constrain governments from } \\
\text { excessive spending. It also serves to } \\
\text { avoid pro-cyclical policies, in } \\
\text { particular, when the use of } \\
\text { higher-than-expected revenues is } \\
\text { defined ex ante in the budget law. }\end{array}$ & $\begin{array}{l}\text { Revenue rules fail to accommodate } \\
\text { macroeconomic stabilisation. } \\
\text { However, they can help to limit the } \\
\text { spending of revenue windfalls in } \\
\text { good times. }\end{array}$ & $\begin{array}{l}\text { Revenue rules can lead to additional } \\
\text { spending, as it is difficult to establish } \\
\text { the cyclical component of revenues. For } \\
\text { instance, in some countries prolonged } \\
\text { booms in property and asset prices led } \\
\text { to additional public expenditure, and } \\
\text { therefore increased the risk of } \\
\text { pro-cyclicality and unsustainable fiscal } \\
\text { policies. }\end{array}$ \\
\hline
\end{tabular}

Source: Adapted from Fall, F. et al. (2015), "Prudent debt targets and fiscal frameworks", OECD Economic Policy Papers, No. 15, OECD Publishing, Paris, https://dx.doi.org/10.1787/5jrxtjmmt9f7-en. 


\subsection{The role of independent fiscal institutions}

IFIs are public institutions with a mandate to critically assess and, in some cases, provide non-partisan advice on fiscal policy and performance (von Trapp, Lienert and Wehner, 2016[147]). In contrast to audit institutions, their assessments are forward-looking (Kopits, 2011 [148]) and unlike independent central banks, they do not have the authority to make policy. Rather, they ensure that unbiased information about the government's fiscal policies and assessments of their implications for public finance sustainability are available. By increasing transparency and accountability, they can help mitigate several of the political issues discussed in Section 4.1 (von Hagen, 2013[149]). This strengthens governments' credibility vis-à-vis citizens and financial markets and enhances the quality of the political debate, ultimately improving the sustainability of public finances (Kopits, 2013[150]). IFIs can also provide expert advice on the question of when escape clauses built into fiscal rules should be activated, thus mitigating the trade-off between rule flexibility and enforceability, as recently demonstrated early in the COVID-19 crisis (OECD, 2020[151] $)$. Against this backdrop, the OECD Council has recognised the importance of IFIs and identified a set of principles to ensure their effectiveness (OECD, 2014[152]).

There are IFIs in three out of four OECD economies, but they vary widely with regard to their mandate and resource endowment (Figure 14). Most IFIs are tasked with the analysis of long-term fiscal sustainability or monitoring fiscal rule compliance. Many also play some role in macroeconomic or fiscal forecasts, though only a small number prepare their country's official forecasts or provide costings of policy measures. IFIs with more demanding mandates, particularly those involved in costing, tend to have more staff at their disposal, for example in Korea, the Netherlands and the United States. IFIs in some of the largest OECD economies, such as Germany and France, have relatively few staff, even though they are expected to endorse forecasts and monitor fiscal rule compliance.

\section{Figure 14. Mandates and resources of IFIs vary widely across the OECD countries}

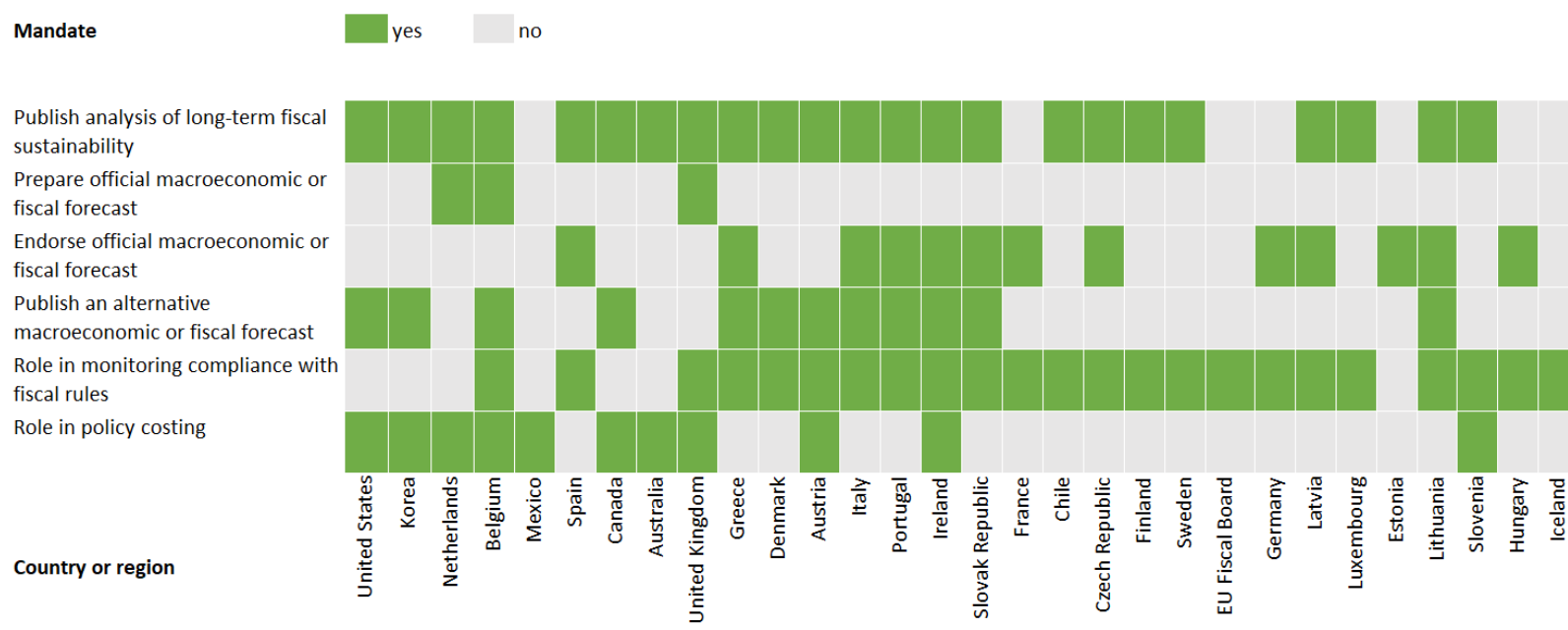

Leadership and staff

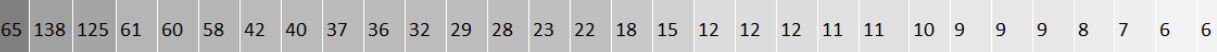

Note: Several OECD countries have chosen to have their official macroeconomic forecasts supplied by an independent organisation other than an IFI, for example, Austria (the Austrian Institute of Economic Research), Finland (an independent body within the Ministry of Finance), Luxembourg (STATEC, the national statistics advisor), Slovenia (the Institute of Macroeconomic Analysis and Development), and Sweden (the National Institute of Economic Research). Canada takes its macroeconomic assumptions from an average of private-sector forecasts. Source: OECD Independent Fiscal Institutions Database 2021. 
The marked differences between IFIs are partly due to the context in which they were established. Most were set up after the GFC, in an effort to reassure financial markets (Table 3). In Europe, a 2013 EU regulation introduced a requirement for the euro area member states to establish national IFIs. This was motivated by the need to ensure governments' compliance with fiscal rules and the importance of independent macroeconomic forecasts. ${ }^{29}$ European laws and treaties not only shaped IFI mandates, they also meant that IFIs were sometimes established without strong political support in their countries, potentially undermining their effectiveness. In other countries, domestic politics rather than external pressure drove the creation of "home-grown" independent institutions (Beetsma et al., 2018[153]). IFIs in Australia, Canada and the United States were created to increase legislative power over the budgetary process (Steuerle and Rennane, 2013 [154]; von Trapp, Lienert and Wehner, 2016[147]). In the Netherlands, one of the first adopters globally, the role of the IFI was influenced by concerns about time inconsistency and the common-pool problem in fiscal policy (Bos and Teulings, 2013 [155]). In general, more long-standing IFIs tend to have a broader remit, including the preparation of own forecasts and the provision of costings of government policies, whereas younger IFIs tend to have fewer and less complex tasks. Some IFIs were established in response to a crisis but not under legal pressure. For example, the creation of a fiscal watchdog in the United Kingdom was motivated by a sharp increase in public debt during the GFC, as well as by concerns over excessively optimistic fiscal forecasts (Chote and Wren-Lewis, 2013 ${ }_{[156]}$ ). Similarly, the Swedish IFI was set up after the financial crisis in the early 1990s (Jonung, 2018[157]).

\section{Table 3. Most independent fiscal institutions are young}

The timing of their foundation

\begin{tabular}{l|r|r|r}
\hline \multicolumn{1}{c|}{ Before 1969 } & $1970-1989$ & $1990-2009$ & 2010-today \\
\hline $\begin{array}{l}\text { Belgium, Denmark and the } \\
\text { Netherlands }\end{array}$ & $\begin{array}{r}\text { Austria and the United } \\
\text { States }\end{array}$ & $\begin{array}{r}\text { Canada, Korea, Mexico } \\
\text { and Sweden }\end{array}$ & $\begin{array}{r}\text { Australia, Chile, Costa Rica, the Czech Republic, } \\
\text { Estonia, Finland, France, Germany, Hungary, } \\
\text { Iceland, Ireland, Italy, Latvia, Lithuania, Luxembourg, } \\
\text { Norway, Portugal, the Slovak Republic, Slovenia, } \\
\text { Spain and the United Kingdom }\end{array}$ \\
\hline
\end{tabular}

Note: Norway's Advisory Committee for Fiscal Policy Analysis has recently had its mandate extended to independently assess the sustainability of fiscal policy, bringing it closer to some European IFls. The Norwegian ministry of finance acts as its secretariat and one committee member is employed by the ministry, though this member is not involved in assessing the sustainability of fiscal policy.

Source: OECD Independent Fiscal Institutions Database 2021; OECD Secretariat.

Research has tentatively associated IFIs with increased fiscal rule compliance and more accurate forecasts, both of which could be interpreted as the results of increased transparency and accountability (Fall et al., 2015 ${ }_{[139]}$; Beetsma et al., 2018[153]). They have also been linked with less pro-cyclical discretionary fiscal policy and, conditional on good institutional design, higher primary balances (Debrun and Kinda, 2017[158]; Martins and Correia, 2020[159]). However, the hypothesised causal mechanism is less direct in these cases. More generally, it has proven hard to disentangle the effects of IFIs from those of other elements of the fiscal framework. IFIs are often introduced as part of a reform package. Moreover, the direction of causality between IFls and fiscal outcomes is contested (Kopits, 2013[160]; von Hagen, $\left.2013_{[149]}\right)$. Fiscal prudence could be the cause, rather than the effect, of strong fiscal frameworks, an issue that some have tried to circumvent by identifying "fiscally prudent" countries ex ante (Debrun and Kumar, 2007 [161]; Martins and Correia, 2020[159]). Still, case studies show numerous positive recent interventions by IFIs (Box 6).

Looking ahead, IFIs could play a more active role in assessing fiscal risks related to the long-term challenges discussed in Section 3, in particular climate change. Some have already started. For instance,

\footnotetext{
${ }^{29}$ See EU regulation No 473/2013 amending the Stability and Growth Pact. Relatedly, the Fiscal Compact commits its signatories to ensuring that independent institutions monitor compliance with fiscal rules.
} 
the Office for Budget Responsibility in the United Kingdom analyses the fiscal risks related to climate change and the fiscal implications of a transition to net zero $\mathrm{CO} 2$ emissions (Office for Budget Responsibility, 2021[71]). Parliamentary Budget Offices in Austria, Canada and the United States also take into account possible budgetary consequences.

\section{Box 6. Country experience with independent fiscal institutions}

Independent fiscal institutions (IFIs) can contribute to responsible public financial management across various areas, including: (1) increasing transparency and accountability; (2) producing or endorsing macroeconomic and fiscal forecasts; (3) monitoring compliance with fiscal rules; (4) assessing long-term fiscal sustainability; and (5) estimating the financial costs of policy proposals.

\section{Increasing transparency and accountability}

All IFIs have the overarching goal of increasing transparency and accountability and have frequently acted to fulfil this objective. For example, in 2018, Finland's IFI reported that the government's medium-term framework publication was missing several key elements required by minimum content legislation, and consequently the government provided the required information in successive publications (OECD, 2021 ${ }_{[64]}$ ). In 2020, the Austrian Parliamentary Budget Office (PBO) highlighted a lack of transparency for COVID-19 emergency measures and argued for comprehensive reporting of costs to parliament. The PBO's criticisms directly led to a parliamentary resolution requiring the government to improve the reporting and traceability of emergency spending (OECD, 2020[151]).

\section{Producing or endorsing macroeconomic and fiscal forecasts}

To limit the temptation of governments to base budgets on too optimistic or too pessimistic assumptions, IFIs are often given the responsibility to produce, endorse, or otherwise scrutinise macroeconomic and fiscal forecasts. For example, in response to concerns over the credibility of the forecasts underpinning UK budgets, the Office for Budget Responsibility was created to prepare five-year economic and fiscal forecasts that the government adopts as the official forecasts for the budget report and mid-year statement (HM Treasury, 2016 $\left[_{[162]}\right.$ ). Likewise, Italy's PBO was mandated with endorsing the budget's macroeconomic assumptions under domestic legislation to meet requirements of the EU's fiscal surveillance framework. In 2016, the Italian PBO determined that the government's forecast was optimistic and declined to endorse it. Following a parliamentary hearing, the government revised its plans using more conservative assumptions (Ufficio parlamentare di bilancio, 2019 [163] .

\section{Monitoring adherence to fiscal rules}

To ensure that fiscal frameworks have impartial referees, many IFIs, particularly those within the EU's fiscal surveillance framework, are mandated with monitoring adherence to fiscal rules, including the activation of escape clauses. For example, the Irish Fiscal Advisory Council is required to confirm the government's compliance with the domestic implementation of the EU fiscal rules. To do so, it developed innovative methods to estimate Irish potential GDP and the output gap, which are notoriously volatile under the EU's commonly agreed methodology, owing to distortions from capital flows and activity related to foreign-owned multinational enterprises (OECD, 2021[68]).

Spain's Independent Authority for Fiscal Responsibility acted quickly during the early stages of the COVID-19 pandemic to assess the potential economic impact of the crisis and the emergency measures that the government announced. It recommended activating the escape clause under Spain's domestic fiscal rules framework and instructed the government to begin working on an action plan to rebalance the public finances as the crisis subsided (OECD, 2020[151]). 


\section{Assessing long-term fiscal sustainability}

Many IFIs are tasked with assessing the long-term fiscal sustainability of official policy periodically. For example, the Canadian Parliamentary Budget Officer produces an annual fiscal sustainability report covering all levels of government and public pension plans. The analysis has been used to challenge official narratives in several high-profile policy debates on changes to the age of eligibility for elderly benefits and adjustments to subnational transfer programmes for health care (Parliamentary Budget Office of Canada, 2021 ${ }_{[164]}$ ). Similarly, the Council for Budget Responsibility of the Slovak Republic is required by law to publish a long-term fiscal sustainability assessment in April each year. In 2018, the Council updated its sustainability assessment to include an estimate of the impact of proposed changes to the national retirement age. The estimate attracted unprecedented media coverage during legislative debates on pension reform (OECD, 2020[165]).

\section{Estimating the financial costs of policy proposals}

To ensure that legislators have a complete picture about implications of various policy proposals, long-established IFIs in the United States, Korea and the Netherlands, along with a growing list of newer IFIs, have been given the responsibility of estimating the financial costs of legislation. For example, the Congressional Budget Office in the United States played a pivotal role in informing debate on the multi-trillion dollar Coronavirus Aid, Relief and Economic Security (CARES) Act. It published a preliminary costing of the Act on 16 April 2020 and responded to subsequent requests from Congress to evaluate other aspects of the economic impact of the Act (OECD, 2020[151]). Similarly, IFIs in Australia, Belgium, Canada and the Netherlands are responsible for independently estimating the cost of measures in political parties' platforms during elections. By bringing greater transparency to the policy debate, these IFIs help ensure that election outcomes are more closely aligned with the intentions of voters and that political parties are more disciplined in their fiscal commitments. 


\section{References}

Aizenman, J. and N. Marion (2011), "Using inflation to erode the US public debt", Journal of Macroeconomics, Vol. 33/4, pp. 524-541, http://dx.doi.org/10.1016/j.jmacro.2011.09.001.

Alesina, A., F. Campante and G. Tabellini (2008), "Why is fiscal policy often procyclical?", Journal of the European Economic Association, Vol. 6/5, pp. 1006-1036, http://dx.doi.org/10.1162/JEEA.2008.6.5.1006.

Alesina, A. et al. (2021), "Austerity and Elections", IMF Working Papers, No. 121, International Monetary Fund, https://www.imf.org/en/Publications/WP/Issues/2021/04/30/Austerity-andElections-50245.

Alesina, A. and G. Tabellini (1990), "A Positive Theory of Fiscal Deficits and Government Debt", The Review of Economic Studies, Vol. 57/3, p. 403, http://dx.doi.org/10.2307/2298021.

Alstadsæter, A., N. Johannesen and G. Zucman (2019), "Tax Evasion and Inequality”, American Economic Review, Vol. 109/6, pp. 2073-2103, http://dx.doi.org/10.1257/aer.20172043.

Alstadsaeter, A., N. Johannesen and G. Zucman (2019), "Tax Evasion and Tax Avoidance", mimeo, http://gabriel-zucman.eu/files/AJZ2018b.pdf.

Alt, J. and D. Lassen (2006), "Fiscal transparency, political parties, and debt in OECD countries", European Economic Review, Vol. 50/6, pp. 1403-1439, http://dx.doi.org/10.1016/j.euroecorev.2005.04.001.

Alt, J. and D. Lassen (2006), "Transparency, political polarization, and political budget cycles in OECD countries", American Journal of Political Science, Vol. 50/3, pp. 530-550, http://dx.doi.org/10.1111/j.1540-5907.2006.00200.x.

Alt, J., D. Lassen and J. Wehner (2014), "It Isn't Just about Greece: Domestic Politics, Transparency and Fiscal Gimmickry in Europe", British Journal of Political Science, Vol. 44/4, pp. 707-716, http://dx.doi.org/10.1017/S0007123414000064.

Andrews, D., A. Charlton and A. Moore (2021), "COVID-19, productivity and reallocation: Timely evidence from three OECD countries", OECD Economics Department Working Papers, No. 1676, OECD Publishing, Paris, https://dx.doi.org/10.1787/d2c4b89c-en.

Andrews, D., C. Criscuolo and P. Gal (2016), "The Best versus the Rest: The Global Productivity Slowdown, Divergence across Firms and the Role of Public Policy", OECD Productivity Working Papers, No. 5, OECD Publishing, Paris, https://dx.doi.org/10.1787/63629cc9-en. 
Andrews, D. et al. (2020), "The career effects of labour market conditions at entry", OECD Productivity Working Papers, No. 20, OECD Publishing, Paris, https://dx.doi.org/10.1787/29c11c75-en.

Andrews, D., J. Hambur and E. Bahar (2021), "The COVID-19 shock and productivity-enhancing reallocation in Australia: Real-time evidence from Single Touch Payroll", OECD Economics Department Working Papers, No. 1677, OECD Publishing, Paris, https://dx.doi.org/10.1787/2f6e7cb1-en.

Ardanaz, M. et al. (2021), "Growth-friendly fiscal rules? Safeguarding public investment from budget cuts through fiscal rule design", Journal of International Money and Finance, Vol. 111, p. 102319, http://dx.doi.org/10.1016/j.jimonfin.2020.102319.

Asatryan, Z., C. Castellón and T. Stratmann (2018), "Balanced budget rules and fiscal outcomes: Evidence from historical constitutions", Journal of Public Economics, Vol. 167, pp. 105-119, http://dx.doi.org/10.1016/J.JPUBEC0.2018.09.001.

Balestra, C. and R. Tonkin (2018), "Inequalities in household wealth across OECD countries: Evidence from the OECD Wealth Distribution Database", OECD Statistics Working Papers, No. 2018/01, OECD Publishing, Paris, https://dx.doi.org/10.1787/7e1bf673-en.

Ball, L. et al. (2016), What Else Can Central Banks Do?, International Center for Monetary and Banking Studies, Centre for Economic Policy Research, https://voxeu.org/content/what-elsecan-central-banks-do.

Bamba, M., J. Combes and A. Minea (2020), "The effects of fiscal consolidations on the composition of government spending", Applied Economics, Vol. 52/14, pp. 1517-1532, http://dx.doi.org/10.1080/00036846.2019.1676392.

Barrage, L. (2020), "The Fiscal Costs of Climate Change", AEA Papers and Proceedings, Vol. 110, pp. 107-112, http://dx.doi.org/10.1257/pandp.20201082.

Baur, M., P. Bruchez and S. Nicol (2021), "Climate Change and Long-term Fiscal Sustainability", Working Party of Senior Budget Officials, OECD, Swiss Finance Administration, https://www.oecd.org/gov/budgeting/scoping-paper-on-fiscal-sustainability-and-climatechange.pdf.

Bean, C. et al. (2015), Low for Long? Causes and Consequences of Persistently Low Interest Rates, CEPR-ICMB, https://voxeu.org/content/low-long-causes-and-consequencespersistently-low-interest-rates.

Beetsma, R. (ed.) (2018), Homegrown: The Swedish fiscal policy framework, VoxEU eBook, https://voxeu.org/content/independent-fiscal-councils-watchdogs-or-lapdogs.

Beetsma, R. et al. (2018), "Independent Fiscal Councils: Recent Trends and Performance", IMF Working Papers, No. 68, International Monetary Fund, https://www.imf.org/en/Publications/WP/Issues/2018/03/23/Independent-Fiscal-CouncilsRecent-Trends-and-Performance-45726.

Beetsma, R., M. Giuliodori and P. Wierts (2009), "Planning to cheat: EU fiscal policy in real time", Economic Policy, Vol. 24/60, pp. 753-804. 
Bergman, U. and M. Hutchison (2015), "Economic stabilization in the post-crisis world: Are fiscal rules the answer?", Journal of International Money and Finance, Vol. 52, pp. 82-101, http://dx.doi.org/10.1016/j.jimonfin.2014.11.014.

Bernanke, B. (2015), "Why are interest rates so low, part 3: The Global Savings Glut", Ben Bernanke's blog, https://www.brookings.edu/blog/ben-bernanke/2015/04/01/why-are-interestrates-so-low-part-3-the-global-savings-glut/.

Bi, H. and E. Leeper (2013), "Analyzing Fiscal Sustainability", Bank of Canada Staff Working Papers, No. 13-27, Bank of Canada, https://ideas.repec.org/p/bca/bocawp/13-27.html.

Bilbiie, F., T. Monacelli and R. Perotti (2021), "Fiscal Policy in Europe: Controversies over Rules, Mutual Insurance, and Centralization", Journal of Economic Perspectives, Vol. 35/2, pp. 77100, http://dx.doi.org/10.1257/JEP.35.2.77.

Blanchard, O. (1990), "Suggestions for a New Set of Fiscal Indicators", OECD Economics Department Working Papers, No. 79, OECD Publishing, Paris, https://dx.doi.org/10.1787/435618162862.

Blanchard, O., Á. Leandro and J. Zettelmeyer (2021), "Redesigning EU fiscal rules: From rules to standards", PIIE Working Papers, No. 1, Peterson Institute for International Economics, https://www.piie.com/publications/working-papers/redesigning-eu-fiscal-rules-rules-standards.

Blanchard, O. and L. Summers (2020), "Automatic Stabilizers in a Low-Rate Environment", AEA Papers and Proceedings, Vol. 110, pp. 125-130, http://dx.doi.org/10.1257/pandp.20201075.

Bloch, D. and F. Fall (2015), "Government debt indicators: Understanding the data", OECD Economics Department Working Papers, No. 1228, OECD Publishing, Paris, https://dx.doi.org/10.1787/5jirxv0ftbff2-en.

Blöchliger, H., D. Song and D. Sutherland (2012), "Fiscal Consolidation: Part 4. Case Studies of Large Fiscal Consolidation Episodes", OECD Economics Department Working Papers, No. 935, OECD Publishing, Paris, https://dx.doi.org/10.1787/5k9fdf5xptlq-en.

Bohn, H. (1998), "The Behavior of U. S. Public Debt and Deficits", The Quarterly Journal of Economics, Vol. 113/3, pp. 949-963, http://dx.doi.org/10.1162/003355398555793.

Bom, P. and J. Ligthart (2014), "What Have We Learned From Three Decades of Research on the Productivity of Public Capital”, Journal of Economic Surveys, Vol. 28/5, pp. 889-916, http://dx.doi.org/10.1111/joes.12037.

Bos, F. and C. Teulings (2013), "Netherlands: Fostering Consensus on Fiscal Policy", in Restoring Public Debt Sustainability, Oxford University Press, http://dx.doi.org/10.1093/acprof:oso/9780199644476.003.0007.

Botev, J., J. Fournier and A. Mourougane (2016), "A Re-assessment of Fiscal Space in OECD Countries", OECD Economics Department Working Papers, No. 1352, OECD Publishing, Paris, https://dx.doi.org/10.1787/fec60e1b-en.

Botta, E. (2019), "A review of "Transition Management" strategies: Lessons for advancing the green low-carbon transition", OECD Green Growth Papers, No. 2019/04, OECD Publishing, Paris, https://dx.doi.org/10.1787/4617a02b-en. 
Bouabdallah, O. et al. (2017), "Occasional Paper Series Debt sustainability analysis for euro area sovereigns: a methodological framework”, ECB Occasional Paper Series, No. 185, European Central Bank, http://dx.doi.org/10.2866/103655.

Bruegel (23 September 2021), "Loan guarantees and other national credit-support programmes in the wake of COVID-19", https://www.bruegel.org/publications/datasets/loan-guaranteesand-other-national-credit-support-programmes-in-the-wake-of-covid-19/ (accessed on 29 October 2021).

Caballero, R., E. Farhi and P. Gourinchas (2017), "Rents, Technical Change, and Risk Premia Accounting for Secular Trends in Interest Rates, Returns on Capital, Earning Yields, and Factor Shares", American Economic Review, Vol. 107/5, pp. 614-620, http://dx.doi.org/10.1257/aer.p20171036.

Calvino, F., C. Criscuolo and R. Verlhac (2020), "Declining business dynamism: Structural and policy determinants", OECD Science, Technology and Industry Policy Papers, No. 94, OECD Publishing, Paris, https://dx.doi.org/10.1787/77b92072-en.

Carnot, N. and F. de Castro (2015), "The discretionary fiscal effort: an assessment of fiscal policy and its output effect", European Economy - Economic Papers, No. 543, https://ec.europa.eu/economy finance/publications/economic paper/2015/ecp543 en.htm.

Carvalho, C., A. Ferrero and F. Nechio (2016), "Demographics and real interest rates: Inspecting the mechanism", European Economic Review, Vol. 88, pp. 208-226, http://dx.doi.org/10.1016/i.euroecorev.2016.04.002.

Caselli, F. and J. Reynaud (2020), "Do fiscal rules cause better fiscal balances? A new instrumental variable strategy", European Journal of Political Economy, Vol. 63, http://dx.doi.org/10.1016/j.ejpoleco.2020.101873.

Caselli, F., D. Stoehlker and P. Wingender (2020), "Individual Treatment Effects of Budget Balance Rules", in IMF Working Paper WP/20/274, https://www.imf.org/en/Publications/WP/Issues/2020/12/11/Individual-Treatment-Effects-ofBudget-Balance-Rules-49919.

Causa, O., J. Browne and A. Vindics (2019), "Income redistribution across OECD countries: Main findings and policy implications", OECD Economic Policy Papers, No. 23, OECD Publishing, Paris, https://dx.doi.org/10.1787/3b63e61c-en.

CBO (2021), Budgetary Effects of Climate Change and of Potential Legislative Responses to It, U.S. Congressional Budget Office, https://www.cbo.gov/publication/57019 (accessed on 21 September 2021).

Cerra, V., A. Fatás and S. Saxena (2020), "Hysteresis and Business Cycles", IMF Working Papers, No. 73, International Monetary Fund, https://www.imf.org/en/Publications/WP/Issues/2020/05/29/Hysteresis-and-Business-Cycles49265.

Chote, R. and S. Wren-Lewis (2013), "United Kingdom: Fiscal Watchdog and Official Forecaster", in Restoring Public Debt Sustainability, Oxford University Press, http://dx.doi.org/10.1093/acprof:oso/9780199644476.003.0012. 
Christiano, L., M. Eichenbaum and S. Rebelo (2011), "When Is the Government Spending Multiplier Large?", Journal of Political Economy, Vol. 119/1, pp. 78-121, http://dx.doi.org/10.1086/659312.

Ciocyte, O., S. Muns and M. Lever (2016), "Determinants of long-term interest rates", CPB Background Documents, CPB Netherlands Bureau for Economic Policy Analysis, https://www.cpb.nl/en/publication/determinants-of-long-term-interest-rates.

Coombes, G. and B. Dollery (2002), "An analysis of the debate on intergenerational equity and fiscal sustainability in Australia", in University of New England School of Economics Working Paper Series in Economics, http://www.une.edu.au/febl/EconStud/wps.htm.

Crivelli, E. et al. (2016), "Fragmented Politics and Public Debt", in IMF Working Papers, http://dx.doi.org/10.5089/9781475537024.001.

De Grauwe, P. and Y. Ji (2013), "Self-fulfilling crises in the Eurozone: An empirical test", Journal of International Money and Finance, Vol. 34, pp. 15-36, http://dx.doi.org/10.1016/j.jimonfin.2012.11.003.

de Renzio, P. and J. Wehner (2017), "The impacts of fiscal openness", World Bank Research Observer, Vol. 32/2, pp. 185-2010.

Debrun, X. and T. Kinda (2017), "Strengthening Post-Crisis Fiscal Credibility: Fiscal Councils on the Rise - A New Dataset", Fiscal Studies, Vol. 38/4, pp. 667-700, http://dx.doi.org/10.1111/1475-5890.12130.

Debrun, X. and M. Kumar (2007), "Fiscal Rules, Fiscal Councils and All that: Commitment Devices, Signaling Tools or Smokescreens?", SSRN Electronic Journal, http://dx.doi.org/10.2139/ssrn.2004371.

Debrun, X. et al. (2019), "Public Debt Sustainability", CEPR Discussion Papers, No. 14010, Centre for Economic Policy Research, https://ideas.repec.org/p/cpr/ceprdp/14010.html.

Dell'Anno, R. and B. Dollery (2013), "Comparative fiscal illusion: a fiscal illusion index for the European Union", Empirical Economics, Vol. 46/3, pp. 937-960, http://dx.doi.org/10.1007/s00181-013-0701-x.

Dollery, B. and A. Worthington (1996), "The Empirical Analysis of Fiscal Illusion", Journal of Economic Surveys, Vol. 10/3, pp. 261-297, http://dx.doi.org/10.1111/j.14676419.1996.tb00014.x.

Égert, B. (2010), "Fiscal Policy Reaction to the Cycle in the OECD: Pro- or Counter-cyclical?", OECD Economics Department Working Papers, No. 763, OECD Publishing, Paris, https://dx.doi.org/10.1787/5kmft7pthb27-en.

Égert, B., J. Botev and D. Turner (2019), "Policy drivers of human capital in the OECD's quantification of structural reforms", OECD Economics Department Working Papers, No. 1576, OECD Publishing, Paris, https://dx.doi.org/10.1787/b8fe3b7b-en.

Égert, B. and P. Gal (2017), "The quantification of structural reforms in OECD countries: A new framework", OECD Economics Department Working Papers, No. 1354, OECD Publishing, Paris, https://dx.doi.org/10.1787/2d887027-en. 
Eggertsson, G., N. Mehrotra and J. Robbins (2019), "A Model of Secular Stagnation: Theory and Quantitative Evaluation", American Economic Journal: Macroeconomics, Vol. 11/1, pp. 1-48, http://dx.doi.org/10.1257/mac.20170367.

Eggertsson, G. et al. (2016), "A contagious malady? Open economy dimensions of secular stagnation”, IMF Economic Review, pp. 581-634, http://dx.doi.org/10.1057/s41308-016-0019$\underline{8}$.

Eggertsson, G., N. Mehrotra and L. Summers (2016), "Secular stagnation in the open economy", American Economic Review, Vol. 106/5, pp. 503-507, http://dx.doi.org/10.1257/aer.p20161106.

Eichenbaum, M. (2019), "Rethinking Fiscal Policy In An Era Of Low Interest Rates", April 2019 Macroeconomic Review, No. Special Feature B, Monetary Authority of Singapore, https://www.mas.gov.sg/publications/economic-essays/2019/rethinking-fiscal-policy-in-an-eraof-low-interest-rates.

EIBerry, N. and S. Goeminne (2021), "Fiscal transparency, fiscal forecasting and budget credibility in developing countries", Journal of Forecasting, Vol. 40, pp. 144-161.

European Commission (2020), "Debt sustainability monitor 2019”, Institutional Papers, No. 120, European Commission Directorate-General for Economic and Financial Affairs, https://ec.europa.eu/info/publications/debt-sustainability-monitor-2019 en (accessed on 20 September 2021).

Eyraud, L. et al. (2018), "Second-Generation Fiscal Rules: Balancing Simplicity, Flexibility, and Enforceability”, in IMF Staff Discussion Notes No. 18/04, https://www.imf.org/en/Publications/Staff-Discussion-Notes/lssues/2018/04/12/SecondGeneration-Fiscal-Rules-Balancing-Simplicity-Flexibility-and-Enforceability-45131.

Eyraud, L. et al. (2020), "How to Design Subnational Fiscal Rules: A Primer", IMF How To Notes, [145] Vol. 2020/1.

Fall, F. et al. (2015), "Prudent debt targets and fiscal frameworks", OECD Economic Policy Papers, No. 15, OECD Publishing, Paris, https://dx.doi.org/10.1787/5jrxtjmmt9f7-en.

Farhi, E. and F. Gourio (2018), "Accounting for macro-finance trends: Market power, intangibles, and risk premia", Brookings Papers on Economic Activity, Brookings, https://www.brookings.edu/bpea-articles/accounting-for-macro-finance-trends-market-powerintangibles-and-risk-premial.

Fatás, A. and L. Summers (2018), "The permanent effects of fiscal consolidations", Journal of International Economics, Vol. 112, pp. 238-250, http://dx.doi.org/10.1016/j.jinteco.2017.11.007.

Furceri, D. et al. (2021), "Recessions and total factor productivity: Evidence from sectoral data", Economic Modelling, Vol. 94, pp. 130-138, http://dx.doi.org/10.1016/j.econmod.2020.09.025.

Furman, J. and L. Summers (2020), "A Reconsideration of Fiscal Policy in the Era of Low Interest Rates", Source: Congressional Budget Office, Mimeo, https://www.piie.com/system/files/documents/furman-summers2020-12-01paper.pdf. 
Gagnon, E., B. Johannsen and D. López-Salido (2021), "Understanding the New Normal: The Role of Demographics", IMF Economic Review, Vol. 69/2, pp. 357-390, http://dx.doi.org/10.1057/s41308-021-00138-4.

Gal, P. et al. (2019), "Digitalisation and productivity: In search of the holy grail - Firm-level empirical evidence from EU countries", OECD Economics Department Working Papers, No. 1533, OECD Publishing, Paris, https://dx.doi.org/10.1787/5080f4b6-en.

Gal, P. and A. Theising (2015), "The macroeconomic impact of structural policies on labour market outcomes in OECD countries: A reassessment", OECD Economics Department Working Papers, No. 1271, OECD Publishing, Paris, https://dx.doi.org/10.1787/5jrqc6t8ktjfen.

Gamper, C. and N. Lamhauge (2021), 2021: Adaptation comes to the fore, OECD Environment Focus, https://oecd-environment-focus.blog/2021/01/25/2021-adaptation-comes-to-the-fore/ (accessed on 20 September 2021).

Gamper, C. and M. Rambali (2021), Climate change mitigation and adaptation: managing two sides of the same coin, OECD Environment Focus, https://oecd-environmentfocus.blog/2021/03/19/climate-change-mitigation-and-adaptation-managing-two-sides-of-thesame-coin/\#more-536 (accessed on 20 September 2021).

Ghosh, A. et al. (2013), "Fiscal Fatigue, Fiscal Space and Debt Sustainability in Advanced Economies", The Economic Journal, Vol. 123/566, pp. F4-F30, http://dx.doi.org/10.1111/ecoj.12010.

Goode, E., Z. Liu and T. Nguyen (2021), "Fiscal Multiplier at the Zero Bound: Evidence from Japan", FRBSF Economic Letters, No. 2021-14, Federal Reserve Bank of San Francisco, https://www.frbsf.org/economic-research/publications/economic-letter/2021/may/fiscalmultiplier-at-zero-bound-evidence-from-japan/.

Gourinchas, P. and H. Rey (2019), "Global real rates: a secular approach", BIS Working Papers, No. 793, Bureau of International Settlements, https://ideas.repec.org/p/bis/biswps/793.html.

Guillemette, Y. and D. Turner (2021), "The Long Game: Fiscal Outlooks to 2060 Underline Need for Structural Reforms", OECD Economics Department Policy Papers, https://doi.org/10.1787/a112307e-en.

Harrison, K. (2013), "The Political Economy of British Columbia's Carbon Tax", OECD Environment Working Papers, No. 63, OECD Publishing, Paris, https://dx.doi.org/10.1787/5k3z04gkkhkg-en.

Heinemann, F., M. Moessinger and M. Yeter (2018), "Do fiscal rules constrain fiscal policy? A meta-regression-analysis", European Journal of Political Economy, Vol. 51, pp. 69-92, http://dx.doi.org/10.1016/j.ejpoleco.2017.03.008.

Hendren, N. and B. Sprung-Keyser (2020), "A Unified Welfare Analysis of Government Policies", The Quarterly Journal of Economics, Vol. 135/3, pp. 1209-1318, http://dx.doi.org/10.1093/qje/qjaa006.

Hepburn, C., J. Pless and D. Popp (2018), "Encouraging Innovation that Protects Environmental Systems: Five Policy Proposals", Review of Environmental Economics and Policy, Vol. 12/1, pp. 154-169, http://dx.doi.org/10.1093/reep/rex024. 
HM Treasury (2016), Charter for Budget Responsibility: Autumn 2016 Update, https://www.gov.uk/government/publications/charter-for-budget-responsibility-autumn-2016update.

IEA (2020), World Energy Outlook 2020, OECD Publishing, Paris, https://dx.doi.org/10.1787/557a761b-en.

Ikeda, D. and M. Saito (2014), "The effects of demographic changes on the real interest rate in Japan", Japan and the World Economy, Vol. 32, pp. 37-48, http://dx.doi.org/10.1016/j.japwor.2014.07.005.

IMF (2020), "Countering Future Recessions in Advanced Economies: Cyclical Policies in an Era of Low Rates and High Debt", World Economic Outlook, No. April 2020, International Monetary Fund, https://www.imf.org/en/Publications/WEO/Issues/2020/04/14/weo-april-2020.

IMF (2013), "Reassessing the Role and Modalities of Fiscal Policy in Advanced Economies", IMF Policy Papers, Vol. 2013/56, http://dx.doi.org/10.5089/9781498341608.007.

Jackson, M. and L. Yariv (2014), "Present Bias and Collective Dynamic Choice in the Lab", American Economic Review, Vol. 104/12, pp. 4184-4204, http://dx.doi.org/10.1257/aer.104.12.4184.

Jordà, Ò., M. Schularick and A. Taylor (2016), "Sovereigns versus banks: Credit, crises, and consequences", Journal of the European Economic Association, Vol. 14/1, pp. 45-79, http://dx.doi.org/10.1111/jeea.12144.

Klein, M. and R. Winkler (2021), "The Government Spending Multiplier at the Zero Lower Bound: International Evidence from Historical Data", Journal of Applied Econometrics, http://dx.doi.org/10.1002/jae.2835.

Koen, V. and P. van den Noord (2005), "Fiscal Gimmickry in Europe: One-Off Measures and Creative Accounting", OECD Economics Department Working Papers, No. 417, OECD Publishing, Paris, https://dx.doi.org/10.1787/237714513517.

Kopits, G. (2013), "Introduction and Overview", in Restoring Public Debt Sustainability, Oxford University Press, http://dx.doi.org/10.1093/acprof:oso/9780199644476.003.0001.

Kopits, G. (ed.) (2013), Restoring Public Debt Sustainability, Oxford University Press, http://dx.doi.org/10.1093/acprof:oso/9780199644476.001.0001.

Kopits, G. (2011), "Independent Fiscal Institutions: Developing Good Practices", OECD Journal on Budgeting, https://dx.doi.org/10.1787/budget-11-5kg3pdgcpn42.

Larrue, P. (2021), "The design and implementation of mission-oriented innovation policies: A new systemic policy approach to address societal challenges", OECD Science, Technology and Industry Policy Papers, No. 100, OECD Publishing, Paris, https://dx.doi.org/10.1787/3f6c76a4-en.

Lisack, N., R. Sajedi and G. Thwaites (2017), "Demographic Trends and the Real Interest Rate", SSRN Electronic Journal, http://dx.doi.org/10.2139/ssrn.3135233.

Londoño-Vélez, J. and J. Ávila-Mahecha (2021), "Enforcing Wealth Taxes in the Developing World: Quasi-Experimental Evidence from Colombia", American Economic Review: Insights, Vol. 3/2, pp. 131-148, http://dx.doi.org/10.1257/aeri.20200319. 
Lorenzoni, G. and I. Werning (2019), "Slow Moving Debt Crises", American Economic Review, Vol. 109/9, pp. 3229-3263, http://dx.doi.org/10.1257/aer.20141766.

Manasse, P. and N. Roubini (2009), "'Rules of thumb” for sovereign debt crises”, Journal of International Economics, Vol. 78/2, pp. 192-205, http://dx.doi.org/10.1016/.jinteco.2008.12.002.

Maravalle, A. and $\measuredangle$. Rawdanowicz (2018), "To shorten or to lengthen? Public debt management in the low interest rate environment", OECD Economics Department Working Papers, No. 1483, OECD Publishing, Paris, https://dx.doi.org/10.1787/192ef3ad-en.

Marten, M. and K. van Dender (2019), "The use of revenues from carbon pricing", OECD Taxation Working Papers, No. 43, OECD Publishing, Paris, https://dx.doi.org/10.1787/3cb265e4-en.

Martins, P. and L. Correia (2020), "Fiscal institutions: different classifications and their effectiveness", Eurasian Economic Review, Vol. 11/1, pp. 159-190, http://dx.doi.org/10.1007/s40822-020-00155-0.

Mauro, P. and J. Zhou (2020), "r minus g negative: Can We Sleep More Soundly?", IMF Working Papers, Vol. 20/52, http://dx.doi.org/10.5089/9781513536071.001.

Mehrotra, N. and D. Sergeyev (2020), "Debt Sustainability in a Low Interest Rate World", CEPR Discussion Papers, No. 15282, Centre for Economic Policy Research, https://cepr.org/active/publications/discussion papers/dp.php?dpno=15282.

Mian, A., L. Straub and A. Sufi (2021), "What explains the decline in $r$ *? Rising income inequality versus demographic shifts", Jackson Hole Economic Symposium, https://www.kansascityfed.org/documents/8337/JH paper Sufi 3.pdf.

Milanez, A. and B. Bratta (2019), "Taxation and the future of work: How tax systems influence choice of employment form”, OECD Taxation Working Papers, No. 41, OECD Publishing, Paris, https://dx.doi.org/10.1787/20f7164a-en.

Mitchener, K. and C. Trebesch (2021), Sovereign Debt in the 21st Century: Looking Backward, Looking Forward, National Bureau of Economic Research, Cambridge, MA, http://dx.doi.org/10.3386/w28598.

Miyamoto, W., T. Nguyen and D. Sergeyev (2018), "Government Spending Multipliers under the Zero Lower Bound: Evidence from Japan", American Economic Journal: Macroeconomics, Vol. 10/3, pp. 247-277, http://dx.doi.org/10.1257/mac.20170131.

Mourão, P. (2008), “Towards a Puviani’s Fiscal Illusion Index”, Hacienda Pública Española / Review of Public Economics, Vol. 187/4, pp. 49-86.

Musgrave, R. (1988), "Public Debt and Intergenerational Equity", in Arrow, K. and M. Boskin (eds.), The Economics of Public Debt, Palgrave Macmillan UK, London, http://dx.doi.org/10.1007/978-1-349-19459-9 5.

Musgrave, R. (1956), "A Multiple Theory of Budget Determination”, FinanzArchiv / Public Finance Analysis, pp. 333-343, https://www.jstor.org/stable/40909134?seq=1\#metadata info tab contents. 
Nerlich, C. and W. Reuter (2013), The design of national fiscal frameworks and their budgetary impact., Working Paper Series 1588, European Central Bank, Frankfurt.

O'Reilly, P. (2018), "Tax policies for inclusive growth in a changing world", OECD Taxation Working Papers, No. 40, OECD Publishing, Paris, https://dx.doi.org/10.1787/1fdafe21-en.

O’Reilly, P., K. Parra Ramirez and M. Stemmer (2019), "Exchange of information and bank deposits in international financial centres", OECD Taxation Working Papers, No. 46, OECD Publishing, Paris, https://dx.doi.org/10.1787/025bfebe-en.

OECD (2021), "Decarbonisation primer: Designing and monitoring strategies to achieve climate change targets while boosting growth and social cohesion", Working Parti No. 1 on Macroeconomic and Structural Policy Analysis, http://ECO/CPE/WP1(2021)22.

OECD (2021), Economic Policy Reforms 2021: Going for Growth: Shaping a Vibrant Recovery, OECD Publishing, Paris, https://dx.doi.org/10.1787/3c796721-en.

OECD (2021), Inheritance Taxation in OECD Countries, OECD Tax Policy Studies, OECD Publishing, Paris, https://dx.doi.org/10.1787/e2879a7d-en.

OECD (2021), OECD Employment Outlook 2021: Navigating the COVID-19 Crisis and Recovery, OECD Publishing, Paris, https://dx.doi.org/10.1787/5a700c4b-en.

OECD (2021), Statement on a Two-Pillar Solution to Address the Tax Challenges Arising From the Digitalisation of the Economy, https://www.oecd.org/tax/beps/statement-on-a-two-pillarsolution-to-address-the-tax-challenges-arising-from-the-digitalisation-of-the-economy-july2021.pdf.

OECD (2021), Tax Administration 2021, OECD, http://dx.doi.org/10.1787/cef472b9-en.

OECD (2021), The State of School Education: One Year into the COVID Pandemic, OECD Publishing, Paris, https://doi.org/10.1787/201dde84-en.

OECD (2020), "Independent Fiscal Institutions: Promoting Fiscal Transparency and Accountability during the Coronavirus Covid-19 Pandemic", https://www.oecd.org/coronavirus/policy-responses/independent-fiscal-institutions-promotingfiscal-transparency-and-accountability-during-the-coronavirus-covid-19-pandemic-d853f8be.

OECD (2020), "Issue Note 3. Post-financial-crisis changes to monetary policy frameworks: Driving factors and remaining challenges", OECD Publishing, Paris, https://dx.doi.org/10.1787/1c91327e-en.

OECD (2020), "OECD Economic Outlook No 108 (Edition 2020/2)", OECD Economic Outlook: Statistics and Projections (database), https://dx.doi.org/10.1787/c59fcffd-en (accessed on 27 July 2021).

OECD (2020), OECD Employment Outlook 2020: Worker Security and the COVID-19 Crisis, OECD Publishing, Paris, https://dx.doi.org/10.1787/1686c758-en.

OECD (2020), OECD Review of the Slovak Council for Budget Responsibility, https://www.oecd.org/gov/budgeting/slovak-republic-independent-fiscal-institution-review2020.htm. 
OECD (2020), OECD Sovereign Borrowing Outlook 2020, OECD Publishing, Paris, https://dx.doi.org/10.1787/dc0b6ada-en.

OECD (2020), The impact of COVID-19 on student equity and inclusion: Supporting vulnerable students during school closures and school re-openings, OECD Publishing, Paris, https://dx.doi.org/10.1787/d593b5c8-en.

OECD (2019), Budgeting and Public Expenditures in OECD Countries 2019, OECD Publishing, Paris, https://dx.doi.org/10.1787/9789264307957-en.

OECD (2019), "Digitalisation and productivity: A story of complementarities", OECD Publishing, Paris, https://dx.doi.org/10.1787/5713bd7d-en.

OECD (2019), "Enhancing Access and Connectivity to Harness Digital Transformation", http://dx.doi.org/10.1787/888933914993.

OECD (2019), OECD Skills Outlook 2019 : Thriving in a Digital World, OECD Publishing, Paris, https://dx.doi.org/10.1787/df80bc12-en.

OECD (2019), Pensions at a Glance 2019: OECD and G20 Indicators, OECD Publishing, Paris, https://dx.doi.org/10.1787/b6d3dcfc-en.

OECD (2018), A Broken Social Elevator? How to Promote Social Mobility, OECD Publishing, Paris, https://dx.doi.org/10.1787/9789264301085-en.

OECD (2018), The Future of Social Protection: What Works for Non-standard Workers?, OECD Publishing, Paris, https://dx.doi.org/10.1787/9789264306943-en.

OECD (2018), "Towards the Implementation of the G20 Roadmap for Digitalisation: Skills, Business Dynamics and Competition", Report prepared at the request of the 2017 G20 German Presidency, https://www.oecd.org/g20/OECDreport Implementation G20 Roadmap.pdf.

OECD (2017), Getting Infrastructure Right: A framework for better governance, OECD Publishing, Paris, https://dx.doi.org/10.1787/9789264272453-en.

OECD (2017), OECD Budget Transparency Toolkit, OECD, http://dx.doi.org/10.1787/9789264282070-en.

OECD (2016), The Economic Consequences of Outdoor Air Pollution, OECD, http://dx.doi.org/10.1787/9789264257474-en.

OECD (2015), The Economic Consequences of Climate Change, OECD Publishing, Paris, https://dx.doi.org/10.1787/9789264235410-en.

OECD (2014), "Recommendation of the Council on Principles for Independent Fiscal Institutions", https://www.oecd.org/gov/budgeting/OECD-Recommendation-on-Principles-forIndependent-Fiscal-Institutions.pdf.

OECD (2011), Fostering Innovation for Green Growth, OECD Green Growth Studies, OECD Publishing, Paris, https://dx.doi.org/10.1787/9789264119925-en.

OECD (1985), "Social expenditure 1960-1990. Problems of growth and control", in OECD Social Policy Studies (ed.), , https://www.oecd.org/social/soc/40836112.pdf. 
OECD/IEA (2021), Update on recent progress in reform of inefficient fossil-fuel subsidies that encourage wasteful consumption, https://www.oecd.org/fossilfuels/publicationsandfurtherreading/OECD-IEA-G20-Fossil-Fuel-Subsidies-Reform-Update2021.pdf.

OECD/The World Bank (2019), Fiscal Resilience to Natural Disasters: Lessons from Country Experiences, OECD Publishing, Paris, https://dx.doi.org/10.1787/27a4198a-en.

Office for Budget Responsibility (2021), Fiscal risks report 2021, https://obr.uk/frr/fiscal-risksreport-july-2021/.

Orr, A., M. Edey and M. Kennedy (1995), "The Determinants of Real Long-Term Interest Rates: 17 Country Pooled-Time-Series Evidence", OECD Economics Department Working Papers, No. 155, OECD Publishing, Paris, https://dx.doi.org/10.1787/375710201525.

Orszag, P., R. Rubin and J. Stiglitz (2021), "Fiscal resiliency in a deeply uncertain world: The role of semiautonomous discretion", PIIE Policy Brief, No. 21-2, Peterson Insitute for International Economics, https://www.piie.com/publications/policy-briefs/fiscal-resiliencydeeply-uncertain-world-role-semiautonomous-discretion.

Pain, N. et al. (2018), "A Model-Based Analysis of the Effect of Increased Public Investment", National Institute Economic Review, Vol. 244/1, pp. R15-R20, http://dx.doi.org/10.1177/002795011824400110.

Pamies, S. and A. Reut (2020), "Assessing public debt sustainability: some insights from an EU perspective into an inexorable question", in Quarterly Report on the Euro Area (QREA), Directorate General Economic and Financial Affairs (DG ECFIN), European Commission, https://ideas.repec.org/a/euf/qreuro/0191-02.html.

Parliamentary Budget Office of Canada (2021), Fiscal Sustainability Report, https://www.pbodpb.gc.ca/en/blog/news/RP-2122-010-S--fiscal-sustainability-report-2021--rapport-viabilitefinanciere-2021.

Persson, T. and L. Svensson (1989), "Why a Stubborn Conservative would Run a Deficit: Policy with Time- Inconsistent Preferences", The Quarterly Journal of Economics, Vol. 104/2, p. 325, http://dx.doi.org/10.2307/2937850.

Persson, T. and G. Tabellini (2004), "Constitutional Rules and Fiscal Policy Outcomes", American Economic Review, Vol. 94/1, pp. 25-45, http://dx.doi.org/10.1257/000282804322970689.

Pettersson-Lidbom, P. (2001), "An Empirical Investigation of the Strategic Use of Debt", Journal of Political Economy, Vol. 109/3, pp. 570-583, http://dx.doi.org/10.1086/321021.

Poghosyan, T. (2014), "Long-run and short-run determinants of sovereign bond yields in advanced economies", Economic Systems, Vol. 38/1, pp. 100-114, http://dx.doi.org/10.1016/j.ecosys.2013.07.008.

Portes, J. and S. Wren-Lewis (2015), "Issues in the Design of Fiscal Policy Rules", The Manchester School, Vol. 83, pp. 56-86, http://dx.doi.org/10.1111/manc.12118. 
Price, R., T. Dang and J. Botev (2015), "Adjusting fiscal balances for the business cycle: New tax [169] and expenditure elasticity estimates for OECD countries", OECD Economics Department Working Papers, No. 1275, OECD Publishing, Paris, https://dx.doi.org/10.1787/5irp1g3282d7en.

Rachel, L. and T. Smith (2015), "Secular drivers of the global real interest rate", Staff Working Papers, No. 571, Bank of England, https://www.bankofengland.co.uk/workingpaper/2015/secular-drivers-of-the-global-real-interest-rate.

Rachel, Ł. and L. Summers (2019), On Secular Stagnation in the Industrialized World, National Bureau of Economic Research, Cambridge, MA, http://dx.doi.org/10.3386/w26198.

Ramey, V. (2019), "Ten Years After the Financial Crisis: What Have We Learned from the Renaissance in Fiscal Research?", Journal of Economic Perspectives, Vol. 33/2, pp. 89-114, http://dx.doi.org/10.1257/jep.33.2.89.

Rawdanowicz, Ł., M. Hammouch and M. Kasai (2017), "The fall in real long-term government bond yields: Disentangling different drivers", OECD Economics Department Working Papers, No. 1398, OECD Publishing, Paris, https://dx.doi.org/10.1787/cb1ff201-en.

Reinhart, C. and M. Sbrancia (2015), "The liquidation of government debt", Economic Policy, Vol. 30/82, pp. 291-333, http://dx.doi.org/10.1093/epolic/eiv003.

Reis, R. (2021), "The constraint on public debt when $r<\mathrm{g}$ but $\mathrm{g}<\mathrm{m}$ ", https://personal.lse.ac.uk/reisr/papers/99-mpkrg.pdf.

Reuter, W. (2015), "National numerical fiscal rules: Not complied with, but still effective?", European Journal of Political Economy, Vol. 39, pp. 67-81, http://dx.doi.org/10.1016/j.ejpoleco.2015.04.002.

Rouzet, D. et al. (2019), "Fiscal challenges and inclusive growth in ageing societies", OECD Economic Policy Papers, No. 27, OECD Publishing, Paris, https://dx.doi.org/10.1787/c553d8d2-en.

Sahm, C. (2019), "Direct stimulus payments to individuals", in Boushey, H., R. Nunn and J. Shambaugh (eds.), Recession ready: Fiscal policies to stabilize the American economy, Brookings Institution, https://www.brookings.edu/research/direct-stimulus-payments-toindividuals/.

Sarin, N. and L. Summers (2019), Shrinking the Tax Gap: Approaches and Revenue Potential, National Bureau of Economic Research, Cambridge, MA, http://dx.doi.org/10.3386/w26475.

Schnabel, I. (2021), "Unconventional fiscal and monetary policy at the zero lower bound", Third Annual Conference organised by the European Fiscal Board on "High Debt, Low Rates and Tail Events: Rules-Based Fiscal Frameworks under Stress", https://www.ecb.europa.eu/press/key/date/2021/html/ecb.sp210226 ff6ad267d4.en.html (accessed on 19 July 2021).

Steuerle, C. and S. Rennane (2013), "United States: Pioneer in Fiscal Surveillance", in Restoring Public Debt Sustainability, Oxford University Press, http://dx.doi.org/10.1093/acprof:oso/9780199644476.003.0006. 
Sutherland, D. et al. (2010), "Counter-cyclical Economic Policy", OECD Economics Department [100] Working Papers, No. 760, OECD Publishing, Paris, https://dx.doi.org/10.1787/5kmfw36ti97hen.

Ter-Minassian, T. (2007), "Fiscal Rules for Subnational Governments: Can They Promote Fiscal Discipline?", OECD Journal on Budgeting, https://dx.doi.org/10.1787/budget-v6-art17-en.

Tinbergen, J. (1952), On the Theory of Economic Policy, North-Holland Pub. Co.

Tryggvadottir, A. (2021 forthcoming), "Best Practices for Spending Reviews", OECD Journal of Budgeting.

Ufficio parlamentare di bilancio (2019), 2019 Budgetary Policy Report, https://www.euifis.eu/download/pbo 2019 budgetary policy report web.pdf.

Vlaicu, R. et al. (2014), "Multiyear budgets and fiscal performance: Panel data evidence", Journal of Public Economics, Vol. 111, pp. 79-95.

Vollrath, D. (2019), Fully Grown: Why a Stagnant Economy Is a Sign of Success, The University of Chicago Press, https://press.uchicago.edu/ucp/books/book/chicago/F/bo44520849.html.

von Hagen, J. (2013), "Scope and Limits of Independent Fiscal Institutions", in Kopits, G. (ed.), Restoring Public Debt Sustainability: The Role of Independent Fiscal Institutions, Oxford University Press, Oxford.

von Hagen, J. and I. Harden (1995), "Budget processes and commitment to fiscal discipline", European Economic Review, Vol. 39/3-4, pp. 771-779, http://dx.doi.org/10.1016/00142921(94)00084-D.

von Trapp, L., I. Lienert and J. Wehner (2016), "Principles for independent fiscal institutions and case studies", OECD Journal on Budgeting, https://dx.doi.org/10.1787/budget-155jm2795tv625.

von Wachter, T. (2020), "The Persistent Effects of Initial Labor Market Conditions for Young Adults and Their Sources", Journal of Economic Perspectives, Vol. 34/4, pp. 168-194, http://dx.doi.org/10.1257/jep.34.4.168.

Woo, J. (2003), "Economic, political, and institutional determinants of public deficits", Journal of Public Economics, Vol. 87/3-4, pp. 387-426, http://dx.doi.org/10.1016/S0047-2727(01)00143$\underline{8}$.

Wyplosz, C. (2012), "Fiscal Rules: Theoretical Issues and Historical Experiences", NBER Chapters, pp. 495-525, http://dx.doi.org/10.3386/W17884.

Zettelmeyer, J., C. Trebesch and M. Gulati (2013), "The Greek debt restructuring: an autopsy", Economic Policy, Vol. 28/75, pp. 513-563, http://dx.doi.org/10.1111/1468-0327.12014. 


\section{Annex A. Country-specific charts with the main fiscal variables}

Figure A A.1. Evolution of the main fiscal variables for individual countries

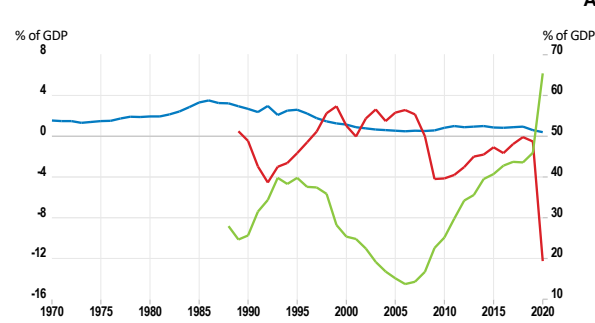

Australia
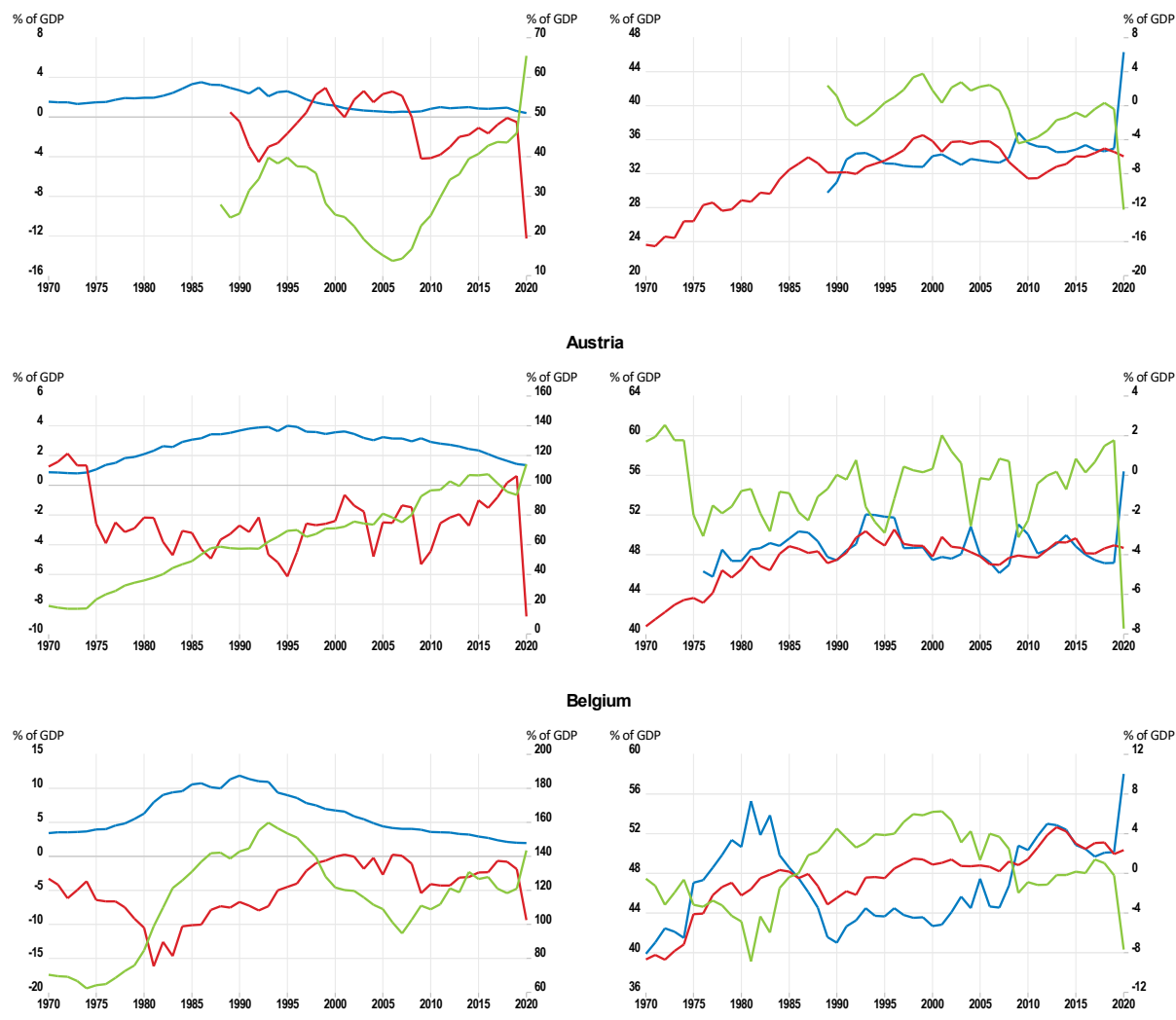

Belgium
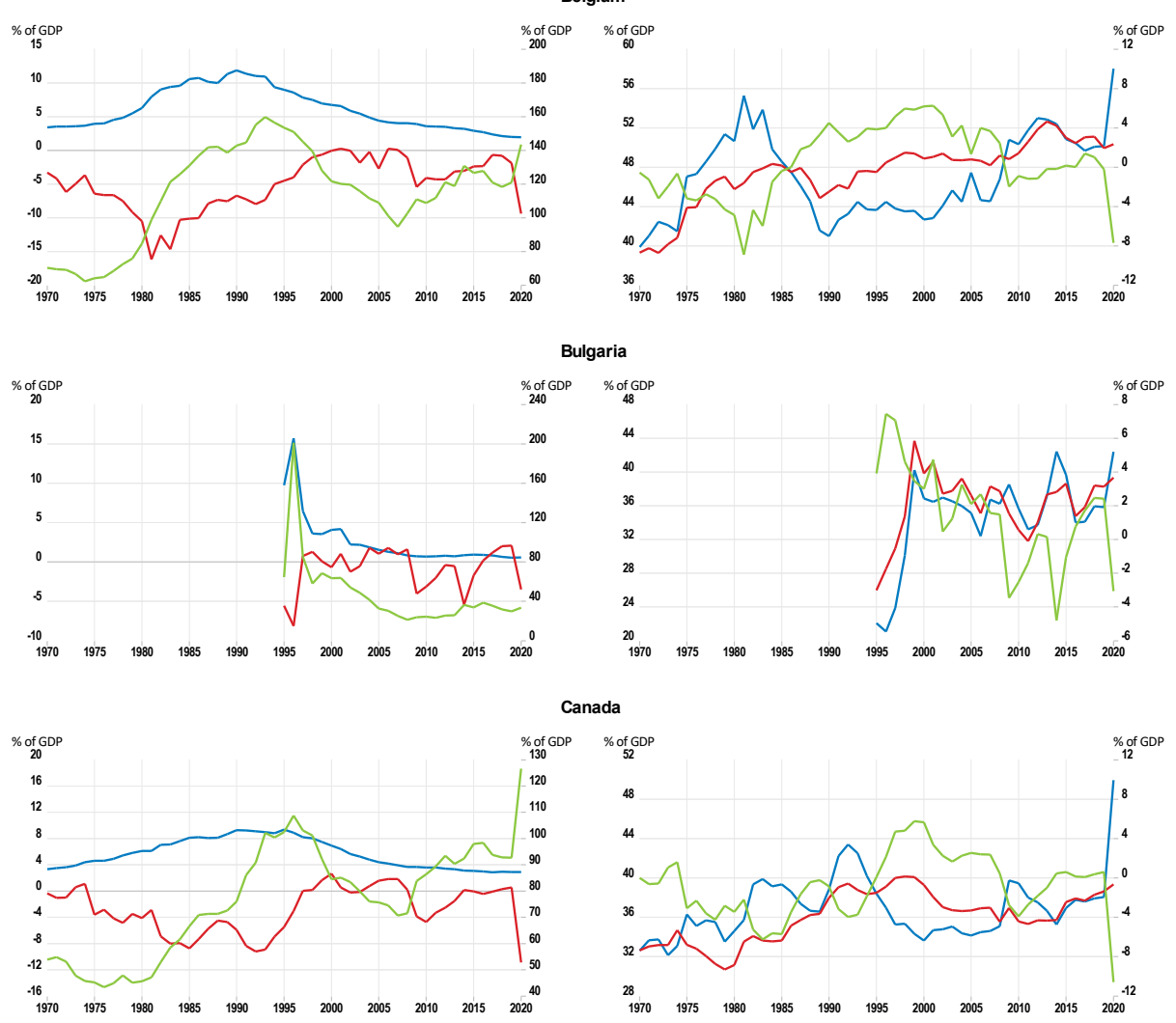

Canada
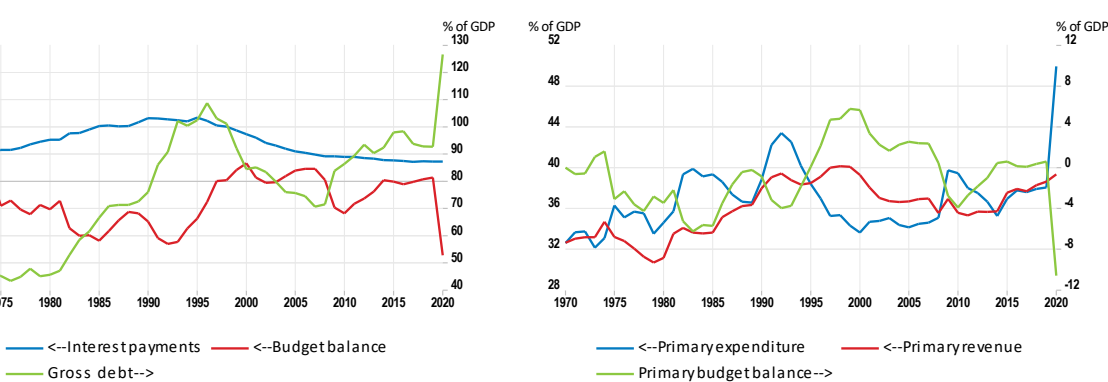

Note: Gross debt refers to the OECD definition of general government financial liabilities.

Source: OECD Economic Outlook database. 
Figure A A.1. Evolution of the main fiscal variables for individual countries (cont'd)
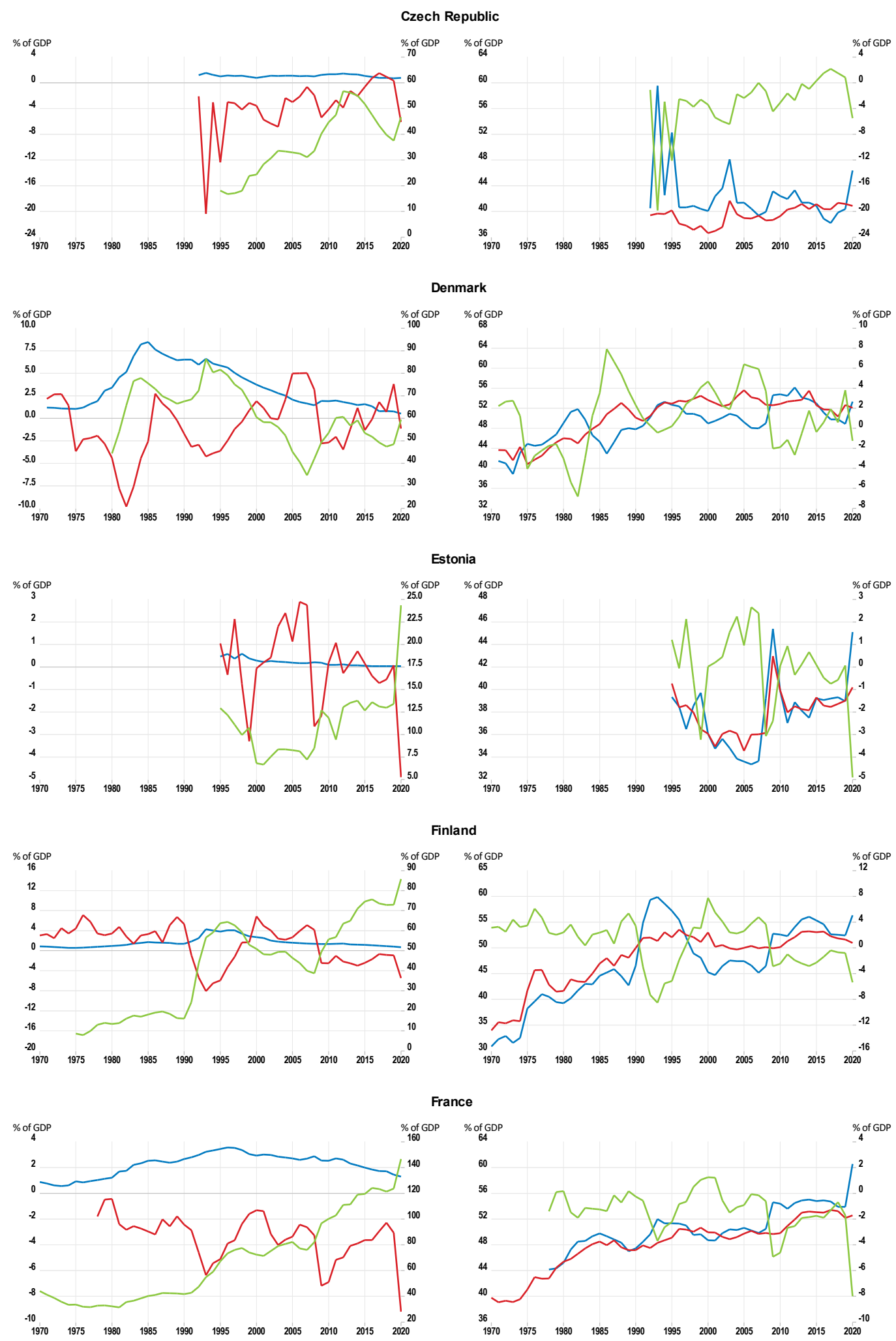

France

$$
\begin{aligned}
& -<- \text { Interest payments }-<- \text { Budget balance } \\
& - \text { Gross debt--> }
\end{aligned}
$$

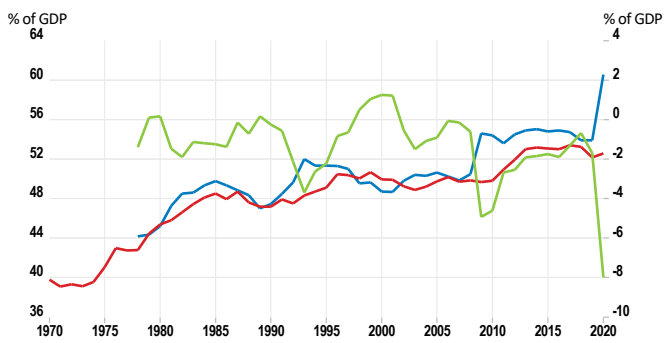

—--Primaryexpenditure —--Primaryrevenue

Note: Gross debt refers to the OECD definition of general government financial liabilities.

Source: OECD Economic Outlook database. 
Figure A A.1. Evolution of the main fiscal variables for individual countries (cont'd)
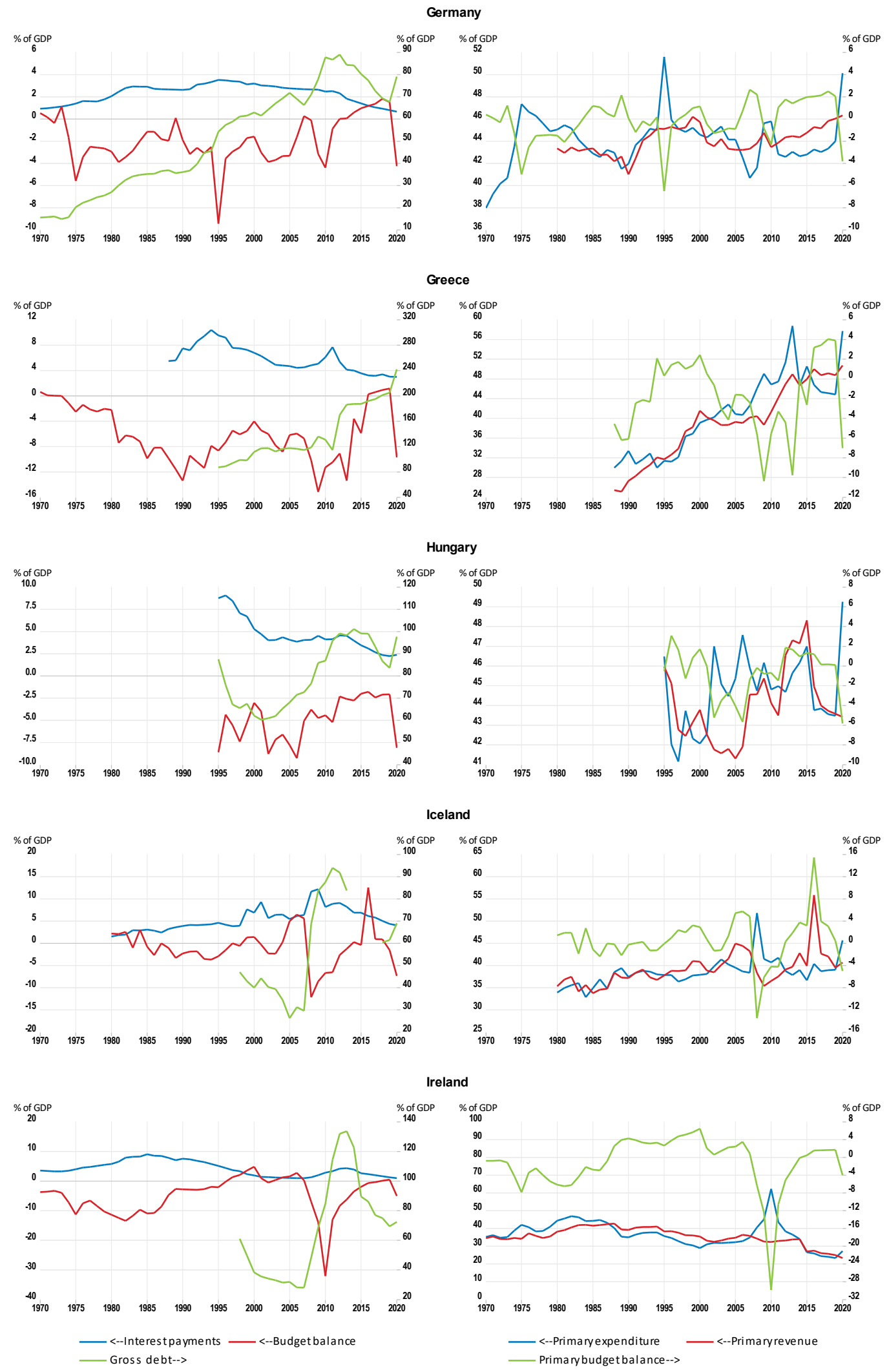

Note: Gross debt refers to the OECD definition of general government financial liabilities.

Source: OECD Economic Outlook database. 
Figure A A.1. Evolution of the main fiscal variables for individual countries (cont'd)
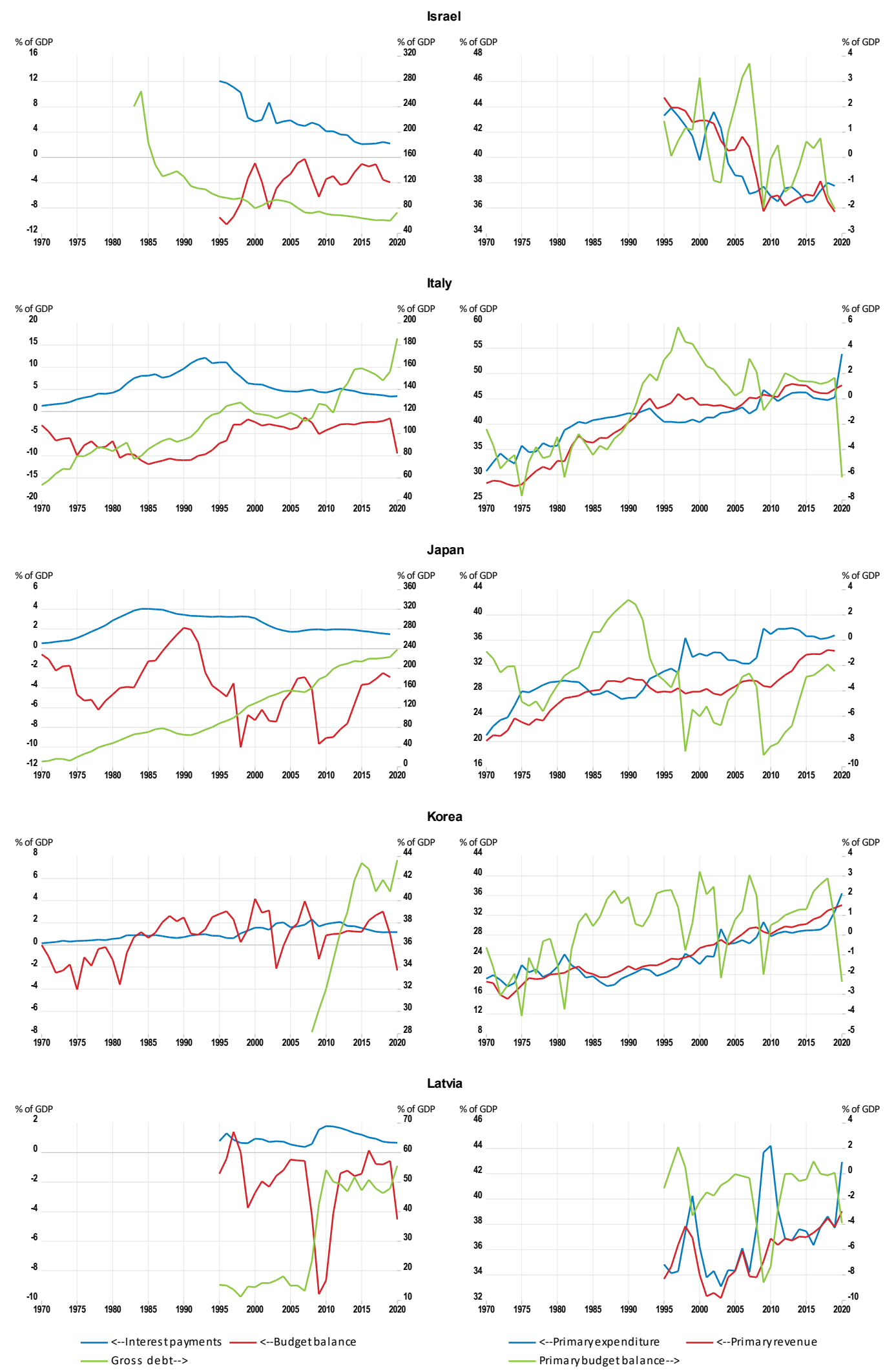

Note: Gross debt refers to the OECD definition of general government financial liabilities.

Source: OECD Economic Outlook database. 
Figure A A.1. Evolution of the main fiscal variables for individual countries (cont'd)
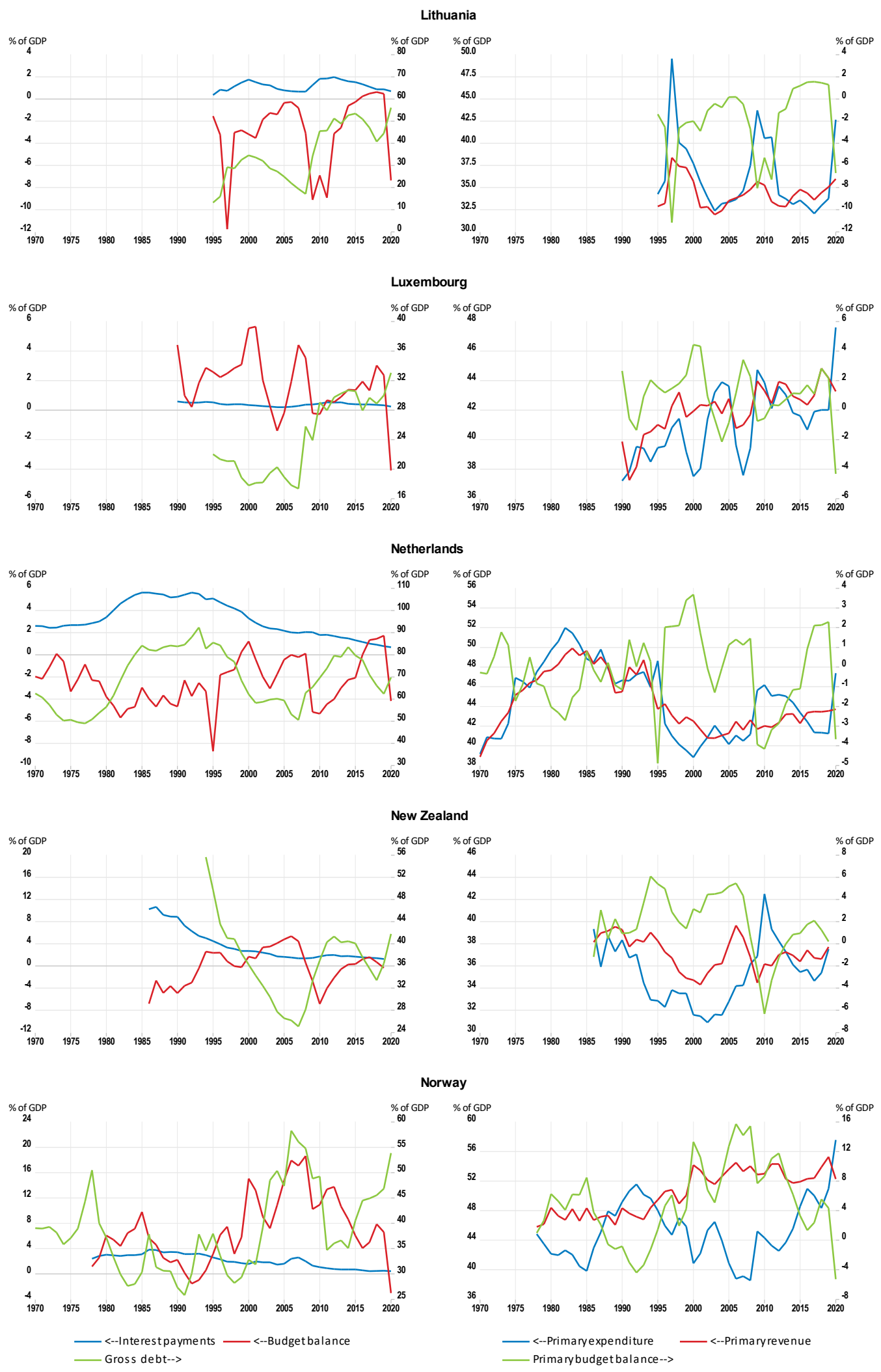

Note: Gross debt refers to the OECD definition of general government financial liabilities.

Source: OECD Economic Outlook database. 
Figure A A.1. Evolution of the main fiscal variables for individual countries (cont'd)

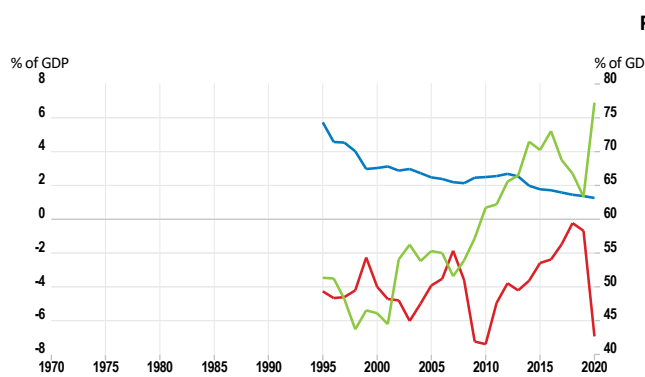

Poland
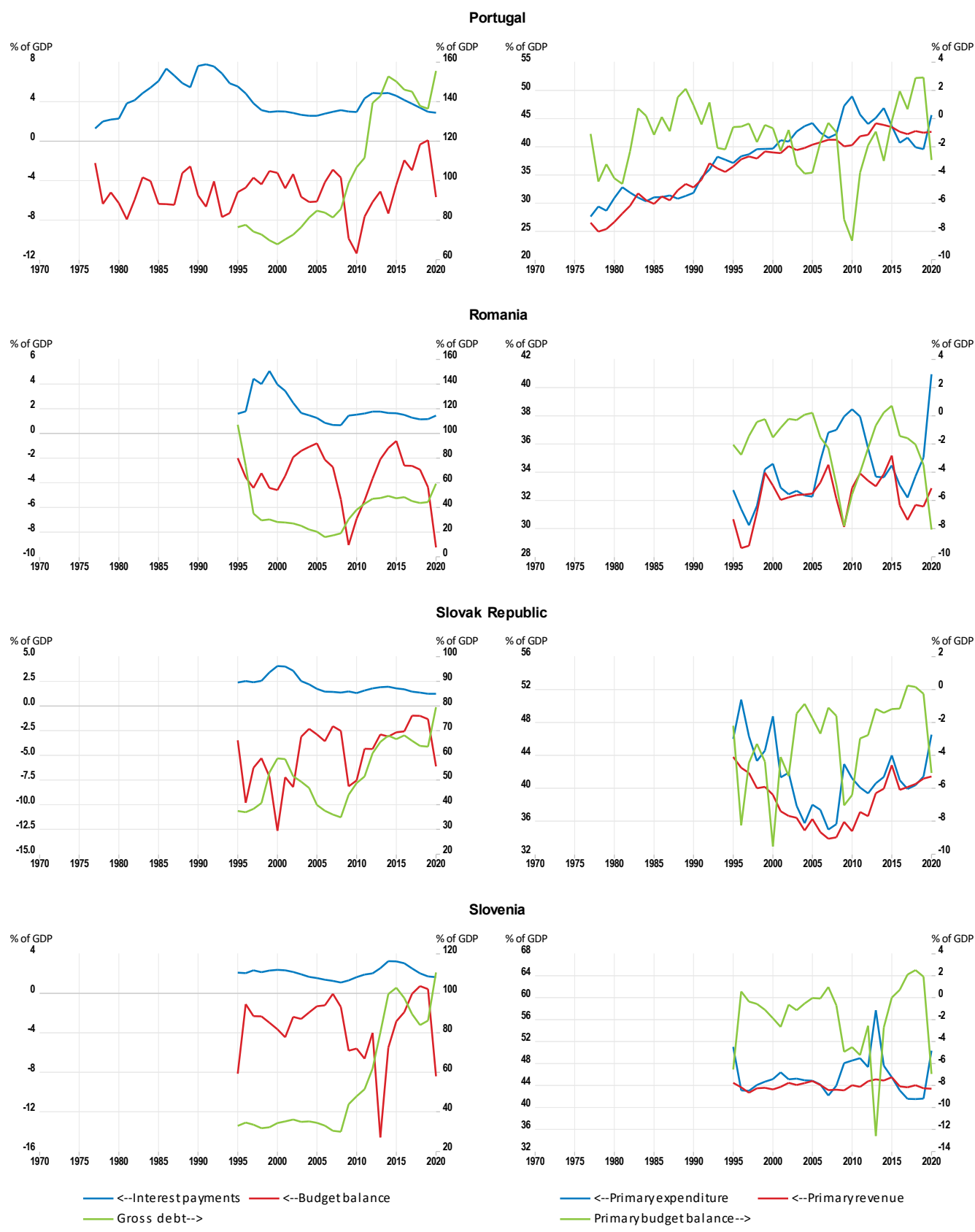

Note: Gross debt refers to the OECD definition of general government financial liabilities.

Source: OECD Economic Outlook database. 
Figure A A.1. Evolution of the main fiscal variables for individual countries (cont'd)
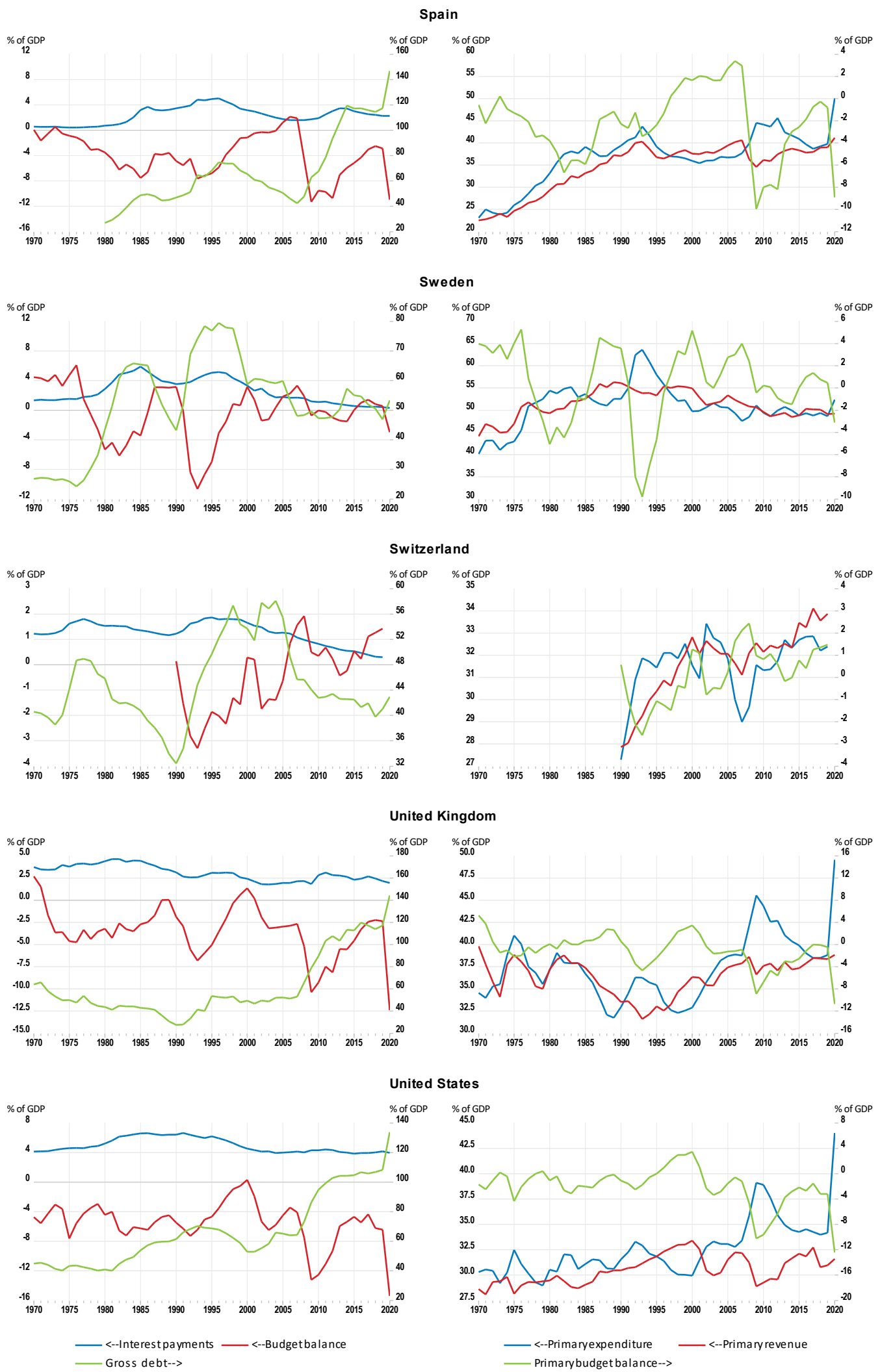

Note: Gross debt refers to the OECD definition of general government financial liabilities.

Source: OECD Economic Outlook database. 


\section{Annex B. Decomposition of debt dynamics and debt measurement issues}

Yearly changes in the ratio of gross debt to GDP can be decomposed according to different formulas. The calculation methods affect the size of contributions of specific components significantly. Since none of the decompositions are clearly superior, the identified driving forces of changes in gross debt differ considerably. The definition of government debt regarding the coverage of various government liabilities and the valuation of these liabilities (market versus nominal value) complicates the assessment further. In this context, the annex explains differences between possible debt decomposition methods and debt measures, and illustrates implications for the assessment of debt dynamics.

\section{Decomposition of debt dynamics and estimates of the effective interest rate paid on debt}

Version 1. According to the national accounts conventions used at the OECD, general government gross debt in nominal values is defined as:

$$
\mathrm{GD}=\mathrm{ND}+\mathrm{FA} \quad=\left[N D_{(-1)}-\mathrm{BB}+\mathrm{SD}\right]+F A \quad=N D_{(-1)}-\mathrm{PB}+\mathrm{NIP}+\mathrm{SD}+\mathrm{FA},
$$

where $G D$ is general government gross debt; $N D$ is net debt; $F A$ is financial assets; $B B$ is the budget balance; $P B$ is the primary budget balance, i.e. the budget balance excluding net interest payments: $P B=$ $B B+N I P$, where NIP denotes net interest payments, defined as the difference between interest paid on debt $(I P)$ and interest earned on financial assets $(I R)$; and $S D$ is the statistical discrepancy.

The above equation can be expressed in terms of ratios to nominal GDP (denoted in small letters):

$$
g d=\left[n d_{(-1)} /(1+g)-b b+s d\right]+f a=n d_{(-1)} /(1+g)-p b+n i p+s d+f a,
$$

where $g$ is the percentage change (in decimal) in nominal GDP $(g=\operatorname{GDP} / G D P(-1)-1)$.

Consequently, the resulting annual change in the ratio of general government gross debt to GDP is given by:

$$
\begin{aligned}
d(g d)=g d-g d_{(-1)} & =-g /(1+g) * n d_{(-1)}-p b+n i p+s d+d(f a) \\
& =\left[n i p-g /(1+g) * n d_{(-1)}\right]-p b+[s d+d(f a)] \\
& =\left[n i p / n d(-1)-g /(1+g){ }^{*} n d(-1)-p b+s f a 1\right. \\
& =[r 1 /(1+g)-g /(1+g)]{ }^{*} n d_{(-1)}-p b+s f a 1 \\
& \approx[r 1-g] * n d_{(-1)}-p b+s f a 1,
\end{aligned}
$$

where $r 1$ is the effective interest rate paid on net debt (NIP/ND(-1)); the so-called "snowball" effect is the product of $(r 1-g) /(1+g)$ and lagged net debt: ${ }^{1}$ and $s f a 1$ is the stock-flow adjustment, i.e. changes in gross debt-to-GDP ratio that are not explained by the primary budget balance and the snowball effect.

\footnotetext{
1 The interest rate-growth differential is equivalent to a weighted difference between the interest rate-growth differentials - the first based on the effective interest rate paid on gross debt (irp $=I P / G D_{(-1)}$ ) and the second is based

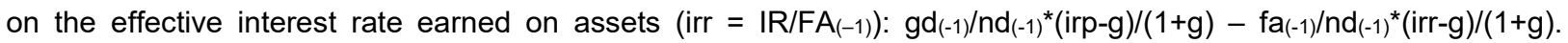
Consequently, the total snowball effect can be expressed as $\left[\mathrm{gd}_{(-1)^{*}}(\operatorname{irp}-\mathrm{g}) /(1+\mathrm{g})-\mathrm{fa}_{(-1)^{*}}(\mathrm{irr}-\mathrm{g}) /(1+\mathrm{g})\right]$.
} 
Version 2. As government financial assets, and thus net debt, are frequently available for shorter periods than gross debt, an alternative decomposition which is often used defines the nominal stock-flow adjustment as the change in nominal gross debt (stock) that is not explained by the budget balance (flow). Thus, nominal gross debt is given as:

$$
\begin{array}{ll}
\mathrm{GD}=\mathrm{GD}_{(-1)}-\mathrm{BB}+\mathrm{SFA2} & =\mathrm{GD}_{(-1)}-\mathrm{PB}+\mathrm{NIP}+\mathrm{SFA2} \\
=\mathrm{GD}_{(-1)}-\mathrm{PB}+\mathrm{IP}+(\mathrm{SFA} 2-\mathrm{IR}) & =\mathrm{GD}_{(-1)}-\mathrm{PB}+\mathrm{IP}+\mathrm{SFA} 2^{*}
\end{array}
$$

where, in contrast to Version 1, to ensure consistency between interest payments and the stock of gross debt and not to modify the definition of the primary balance, interest earned on financial assets is added to the stock-flow adjustment. ${ }^{2}$

As above, the annual change in the ratio of general government gross debt to GDP is then given by:

$$
\begin{aligned}
\mathrm{d}(\mathrm{gd}) & =\left[\mathrm{ip} / g \mathrm{gd}_{(-1)}-\mathrm{g} /(1+\mathrm{g})\right]^{*} \mathrm{gd}_{(-1)}-\mathrm{pb}+(\mathrm{sfa} 2-\mathrm{ir}) \\
& =[\mathrm{r} 2 /(1+\mathrm{g})-\mathrm{g} /(1+\mathrm{g})]^{*} \mathrm{gd}_{(-1)}-\mathrm{pb}+\mathrm{sfa2}^{*} \\
& \approx[\mathrm{r} 2-\mathrm{g}]^{*} \mathrm{gd}(-1)-\mathrm{pb}+\mathrm{sfa2}{ }^{*},
\end{aligned}
$$

where $r 2$ is the effective interest rate paid on gross debt $(r 2=\operatorname{IP} / G D(-1))$.

The two versions of debt decompositions have advantages and disadvantages. Version 1 accounts precisely for changes in financial assets. However, when net debt is close to zero the effective interest rate paid on net debt ( $\mathrm{r} 1$ ) can be very high and it can be negative when net interest payments and net debt are of the opposite signs. Moreover, data availability sometimes prevent using this decomposition over very long periods. Version 2 addresses these challenges, but leaves a part of the stock-flow adjustment unexplained, as changes in assets usually play a significant role in debt accumulation (debt can be issued to finance asset purchases and not a budget deficit).

Given that the definition of the primary balance is the same in both decompositions, the differences between the two versions of decomposing government gross debt reflect the differences in the snowball effect and the stock-flow adjustment (Table A B.1). For the majority of countries, the contribution of the snowball effect to debt dynamics is much larger in Version 1 than in Version 2. On average across countries, its contribution is positive in Version 1, while it is slightly negative in Version 2 . The exact opposite is the case for the stock-flow adjustment. For many countries, the evolution over time of the snowball effect and the stock-flow adjustment are similar in both versions, but in some cases, they differ considerably.

\section{Definition of gross debt}

Measures of government debt and liabilities differ - among other aspects - in financial instrument coverage and the valuation method of the financial instruments (market value, nominal value or face value) (Bloch and Fall, 2015 $[166]$ ). According to the latest System of National Accounts (SNA) conventions, general government gross debt includes the following liabilities: special drawing rights (SDRs) holdings; currency and deposits; debt securities; loans; insurance, pensions and standardised guarantee schemes; and other accounts payable. ${ }^{3}$ Thus, all debt components are liabilities but some liabilities such as shares, equity,

\footnotetext{
${ }^{2}$ IMF (2010) modifies the primary balance (PB2 = PB + IR) rather than the stock-flow adjustment. Interests earned on assets can be large (on average for all countries in this paper and across time around $1 \%$ of GDP). Thus, the primary balance augmented by interest earned can differ significantly from the standard definition.

${ }^{3}$ Other accounts payable cover trade credits, advances and miscellaneous accounts payable. The latter includes accrued but unpaid taxes, dividends, purchase and sales of securities, rent, wages and salaries, social contributions and social benefits; payments that have not yet accrued such as prepayments of taxes; liabilities arising from the
} 
investment fund shares, employee stock options and financial derivatives are not considered as debt instruments because they do not require the payment of principal or interest.

Table A B.1. Comparison of annual average contributions to changes in debt according to different versions of debt decompositions

\begin{tabular}{|c|c|c|c|c|c|c|c|c|c|c|c|}
\hline & \multirow{3}{*}{$\begin{array}{c}\text { Change } \\
\text { in gross } \\
\text { debt }\end{array}$} & \multicolumn{2}{|c|}{ Snowball effect } & \multirow{2}{*}{\multicolumn{2}{|c|}{ Primary balance }} & \multirow{2}{*}{\multicolumn{2}{|c|}{ Stock-flow adjustment }} & \multicolumn{4}{|c|}{ Memorandum } \\
\hline & & & & & & & & $r-g$ & & start & end \\
\hline & & $\mathrm{V} 1$ & V2 & $\mathrm{V} 1$ & V2 & V1 & V2 & V1 & V2 & & \\
\hline Australia & 1.2 & 1.4 & -0.2 & 0.4 & 0.4 & -0.6 & 1.0 & -27.6 & -1.0 & 1989 & 2020 \\
\hline Austria & 2.0 & 1.0 & 0.5 & 0.7 & 0.7 & 0.3 & 0.8 & 3.3 & 0.8 & 1981 & 2020 \\
\hline Belgium & 1.4 & 1.5 & 0.8 & -0.5 & -0.5 & 0.3 & 1.0 & 1.3 & 0.3 & 1970 & 2020 \\
\hline Bulgaria & -1.4 & 11.3 & -9.6 & -1.6 & -1.6 & -11.2 & 9.7 & -34.0 & -8.1 & 1996 & 2019 \\
\hline Canada & 1.4 & 0.3 & 1.7 & 0.8 & 0.8 & 0.3 & -1.0 & -0.6 & 2.1 & 1970 & 2020 \\
\hline Czech Republic & 1.1 & 1.8 & -0.5 & 2.1 & 2.1 & -2.7 & -0.4 & -6.3 & -1.6 & 1996 & 2020 \\
\hline Denmark & 0.4 & 1.6 & 1.2 & -1.6 & -1.6 & 0.4 & 0.8 & 8.2 & 1.8 & 1981 & 2020 \\
\hline Estonia & 0.5 & 2.6 & -0.7 & 0.1 & 0.1 & -2.2 & 1.1 & -8.0 & -6.4 & 1996 & 2020 \\
\hline Finland & 1.7 & 1.4 & 0.0 & -0.7 & -0.7 & 1.0 & 2.4 & -5.7 & 0.1 & 1976 & 2020 \\
\hline France & 2.7 & 1.3 & 0.1 & 1.3 & 1.3 & 0.1 & 1.2 & -123.9 & -0.4 & 1978 & 2020 \\
\hline Germany & 1.2 & 1.1 & 0.6 & 0.2 & 0.2 & 0.0 & 0.4 & 3.2 & 1.4 & 1970 & 2020 \\
\hline Greece & 6.2 & 3.9 & 4.1 & 1.6 & 1.6 & 0.7 & 0.5 & 4.0 & 2.7 & 1996 & 2020 \\
\hline Hungary & 0.4 & 0.7 & -1.6 & 0.7 & 0.7 & -1.0 & 1.3 & 2.1 & -2.0 & 1996 & 2020 \\
\hline Iceland & 2.4 & 1.1 & 4.5 & 0.3 & 0.3 & 1.1 & -2.3 & 64.7 & 9.5 & 1999 & 2013 \\
\hline Ireland & 0.5 & -1.1 & -2.6 & 1.8 & 1.8 & -0.2 & 1.4 & 32.3 & -3.2 & 1999 & 2020 \\
\hline Israel & -1.7 & -0.1 & 0.1 & -0.4 & -0.4 & -1.2 & -1.4 & -0.2 & 0.1 & 1995 & 2019 \\
\hline Italy & 2.6 & 0.9 & -0.5 & 0.7 & 0.7 & 0.9 & 2.3 & -0.4 & -1.5 & 1970 & 2020 \\
\hline Japan & 4.4 & 0.5 & 0.7 & 3.2 & 3.2 & 0.7 & 0.4 & -0.5 & -0.1 & 1971 & 2018 \\
\hline Latvia & 1.6 & 0.9 & -0.6 & 1.4 & 1.4 & -0.7 & 0.9 & -11.9 & -3.2 & 1996 & 2020 \\
\hline Lithuania & 1.7 & 1.6 & -1.0 & 2.0 & 2.0 & -1.9 & 0.7 & -5.1 & -3.1 & 1996 & 2020 \\
\hline Luxembourg & 0.4 & 2.0 & -0.9 & -1.0 & -1.0 & -0.6 & 2.3 & -4.1 & -3.9 & 1996 & 2020 \\
\hline Netherlands & 0.1 & 1.0 & 0.0 & 0.2 & 0.2 & -1.0 & 0.0 & 3.8 & -0.3 & 1971 & 2020 \\
\hline New Zealand & -0.8 & 0.3 & 0.3 & -1.8 & -1.8 & 0.7 & 0.8 & 1.7 & 0.7 & 1995 & 2019 \\
\hline Poland & 1.0 & 1.1 & -1.5 & 1.7 & 1.7 & -1.8 & 0.8 & 154.2 & -2.6 & 1996 & 2020 \\
\hline Portugal & 3.2 & 1.2 & 0.6 & 1.6 & 1.6 & 0.3 & 0.9 & 1.6 & 0.4 & 1996 & 2020 \\
\hline Romania & -1.9 & 10.8 & -5.0 & 2.1 & 2.1 & -14.8 & 1.0 & -17.3 & -10.8 & 1996 & 2020 \\
\hline Slovak Republic & 1.7 & 1.1 & -0.8 & 3.1 & 3.1 & -2.5 & -0.7 & 7.1 & -1.6 & 1996 & 2020 \\
\hline Slovenia & 3.1 & 2.3 & -0.4 & 1.6 & 1.6 & -0.9 & 1.9 & 6.1 & -1.2 & 1996 & 2020 \\
\hline Spain & 3.0 & 0.6 & -0.1 & 2.3 & 2.3 & 0.1 & 0.8 & -0.1 & -1.0 & 1981 & 2020 \\
\hline Sweden & 0.5 & 1.3 & -0.4 & -0.3 & -0.3 & -0.5 & 1.2 & -15.2 & -1.2 & 1971 & 2020 \\
\hline Switzerland & -0.7 & 0.4 & -0.3 & -0.8 & -0.8 & -0.3 & 0.4 & 2.7 & -0.5 & 2000 & 2019 \\
\hline United Kingdom & 3.1 & 0.9 & 0.1 & 1.7 & 1.7 & 0.5 & 1.3 & -1680.8 & 0.5 & 1988 & 2020 \\
\hline United States & 1.8 & 1.1 & 1.6 & 2.0 & 2.0 & -1.4 & -1.9 & 3.0 & 2.8 & 1970 & 2020 \\
\hline Mean & 1.4 & 1.8 & -0.3 & 0.8 & 0.8 & -1.1 & 0.9 & -49.8 & -0.9 & & \\
\hline Median & 1.4 & 1.1 & -0.1 & 0.7 & 0.7 & -0.3 & 0.8 & -0.1 & -0.5 & & \\
\hline
\end{tabular}

Note: V1 and V2 refer to Version 1 and Version 2 of debt decomposition as described in the text above. For each country, both decompositions are based on the same sample. Extreme $r$-g values for some countries based on Version 1 reflect a single-year outcome when lagged net debt was close to zero - see the main text.

Source: OECD Economic Outlook database; and authors' calculations.

payment of benefits that were due to be paid from social security schemes but have not yet been paid; unpaid hospital and medical bills. 
The choice of the valuation method of financial instruments is relevant for the economic interpretation of debt. According to SNA convention, tradeable financial instruments (such as debt securities) should be valued at market value, while financial liabilities that are not traded should be recorded at nominal/face value. ${ }^{4}$ The valuation of debt instruments at market prices is informative for investors, who would like to trade government debt securities, or for a government, which would like to buy back its bonds. The valuation of debt at nominal/face value, instead, is more relevant for assessing financing needs, rollover risks and debt sustainability.

International organisations tend to use definitions of general government liabilities/debt that differ in instrument coverage and valuation method, making comparison difficult.

- General government gross financial liabilities as the main measure of debt is used in the OECD Economic Outlook (EO). It covers all debt liabilities plus two non-debt liabilities (equity and investment fund shares; and financial derivatives and employee stock options). ${ }^{5}$ The liability "Insurance, pension and standardised guarantee schemes" is excluded, as it is reported by a limited number of countries that do not always use the same methodology, making international comparability difficult. ${ }^{6}$ Debt securities, equity and investment fund shares, financial derivatives and employee stock options are valued at market prices; all remaining liabilities are expressed at nominal/face value. ${ }^{7}$

- The European Union uses the so-called Maastricht debt definition within the fiscal framework of the Stability and Growth Pact. The Maastricht debt includes only: currency and deposits, debt securities and loans. All liabilities are expressed at nominal/face values. The Bank for International Settlement (BIS) publishes the "core" government debt, which is equivalent to the Maastricht definition.

Diverse composition of debt and valuation conventions can result in significantly different debt levels and, consequently, differences in the effective interest rate paid on debt, with implications for debt sustainability analysis. The difference between EO debt and Maastricht debt can be explained by coverage and valuation effects. The former reflects differences in the instrument coverage, while the latter originates from adopting different valuation conventions for debt securities. A third debt measure, which has the same instrument coverage as Maastricht debt but values debt securities at market prices as EO debt, is used to separate these two effects.

- For available countries, debt expressed at market values (loans and debt securities) tends to exceed its nominal value. The positive differences in debt valuation have increased over the past decade, reflecting in most cases falling interest rates (bond prices and interest rates move inversely). The cross-country median difference between 2008 and 2020 was close to $5 \%$ of GDP, but - in some countries - it exceeded 10\% of GDP (Austria, Belgium, France, Japan, Spain and the United Kingdom). In few instances during the euro area sovereign debt crisis, due to a large

\footnotetext{
${ }^{4}$ The nominal value of a financial instrument is the sum of funds originally advanced, plus any subsequent advances less any repayments, plus any accrued interest not yet paid. The face value refers only to the principal amount to be repaid at maturity. While it is preferable to record debt liabilities at nominal value, often only the face value of a liability is available. The difference between the face and the nominal value of debt securities is usually small, but can be significant when zero-coupon and deep-discount securities account for a large share of debt liabilities.

${ }^{5}$ The size of non-debt liabilities is usually small relative to GDP and total debt; only in a limited number of countries it is above $0.5 \%$ of GDP: Austria (equity liabilities are $4.5 \%$ of GDP), Finland, Greece (financial derivatives are $2.2 \%$ of GDP), Ireland, Italy (financial derivatives are $2.2 \%$ of GDP), Latvia, Portugal and Sweden.

${ }^{6}$ Only few countries report sizeable insurance and pension liabilities: Australia (29.8\% of GDP), the United States (28.4\% of GDP), Canada (14.5\% of GDP) and Sweden (9.4\% of GDP; all in 2019). Moreover, countries with a fully funded pension system will record larger liabilities than countries with an unfunded pension system.

7 The United States is an exception as debt securities are reported at face/nominal value.
} 
drop in government bond prices in 2011, the market value of debt securities fell below their face value by more than $70 \%$ of GDP in Greece, $18 \%$ of GDP in Portugal and $8 \%$ of GDP in Italy.

- For a given amount of interest payments, using a narrow debt definition that includes deposits, loans and debt securities only (the latter expressed at nominal/face value) increases the effective interest rate paid on debt compared with the rate based on the wider EO debt definition. In 2018 , for a sample of 27 OECD countries, the difference was on average around 40 basis points, reflecting both the liability coverage (red bars in Figure A B.1) and the valuation effects of debt securities (blue bars in Figure A B.1). In Austria, Denmark, Hungary, Poland, the Slovak Republic and the United Kingdom, the difference was more than 50 basis points.

Figure A B.1. Differences in the effective interest paid on debt according to different debt definitions

The decomposition of the difference in Maastricht and OECD effective interest paid on debt, percentage points

2018

1.0

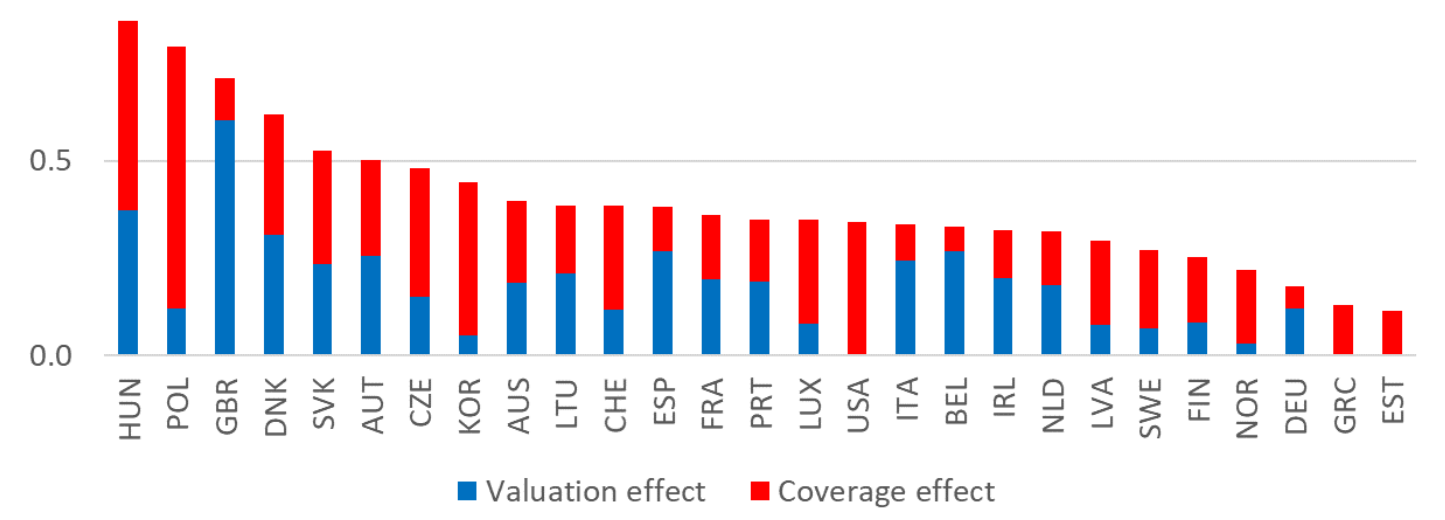

Note: The effective interest rate paid on debt is computed as the ratio of general government interest payments over debt from the preceding year. Two measures of debt are considered: Maastricht debt, which consists of deposits, loans and debt securities (measured at nominal value/face value); and EO debt (general government financial liabilities excluding insurance, pension and standardised guarantee schemes). For Iceland, the most recent data are from 2014. The coverage effect reflects differences in the instrument coverage, while the valuation effect originates from adopting different valuation conventions for debt securities.

Source: OECD Financial accounts; OECD Quarterly Public Sector Debt; OECD Economic Outlook database; and authors' calculations. 


\section{Annex C. Debt stabilisation with negative interest-growth differentials}

This annex presents stylised simulations to show debt stabilisation outcomes with negative interest-growth differentials $(r-g)$ depending on their key determinants as explained in Annex B: initial debt, primary budget balance and $r-g$. While debt always stabilises with a negative $r-g$, such stabilisation can take a very long time and be at a very high level.

The size of the negative $r-g$ and the primary budget balance are fundamental for determining the speed and the level of the debt-to-GDP ratio stabilisation, while initial debt is less important.

- For instance, with a permanent primary budget deficit of $3 \%$ of GDP and initial debt of $80 \%$ of GDP, increasing the $r-g$ from -3 to -1 percentage points extends the duration of debt stabilisation by more than three times (from 61 to nearly 300 years) and nearly triples the debt stabilisation level (from $100 \%$ to nearly $300 \%$ of GDP), resulting in a considerably higher increase in the debt-to-GDP ratio in the first ten years (Figure A C.1, left column).

- Similarly, doubling the primary budget deficit from $2 \%$ to $4 \%$ of GDP could result in more than twice as long stabilisation and at twice as high debt, assuming a permanent negative $r-g$ of 2 percentage points and initial debt at $80 \%$ of GDP (Figure A C.1, middle column).

- For a given permanent level of the primary budget balance and the negative $r$-g, initial debt does not affect the level at which debt stabilises but only the number of years it takes to do so (Figure A C.1, right column). ${ }^{8}$

\footnotetext{
${ }^{8}$ A ratio of gross debt to GDP in time $t$ is a function of initial debt $\left(d_{0}\right)$, the primary balance, the interest rate paid on debt $(r)$ and the nominal GDP growth rate $(g): \mathrm{d}_{t}=\mathrm{d}_{0} * x^{t}-\mathrm{pb} *\left(1-x^{t}\right) /(1-\mathrm{x})$, where $x=(1+\mathrm{r}) /(1+\mathrm{g})$. Thus, when $r<g$ (implying that $x<1$ ) and $t$ is very large, initial debt ceases to affect the debt ratio in a distant future as $x^{t}$ converges to zero.
} 
Figure A C.1. Stabilisation of the debt-to-GDP ratio with a negative $r-g$

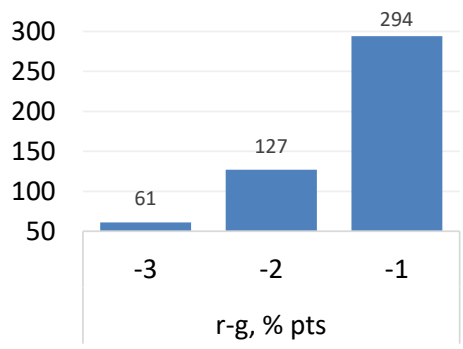

A. Number of years to stabilise debt
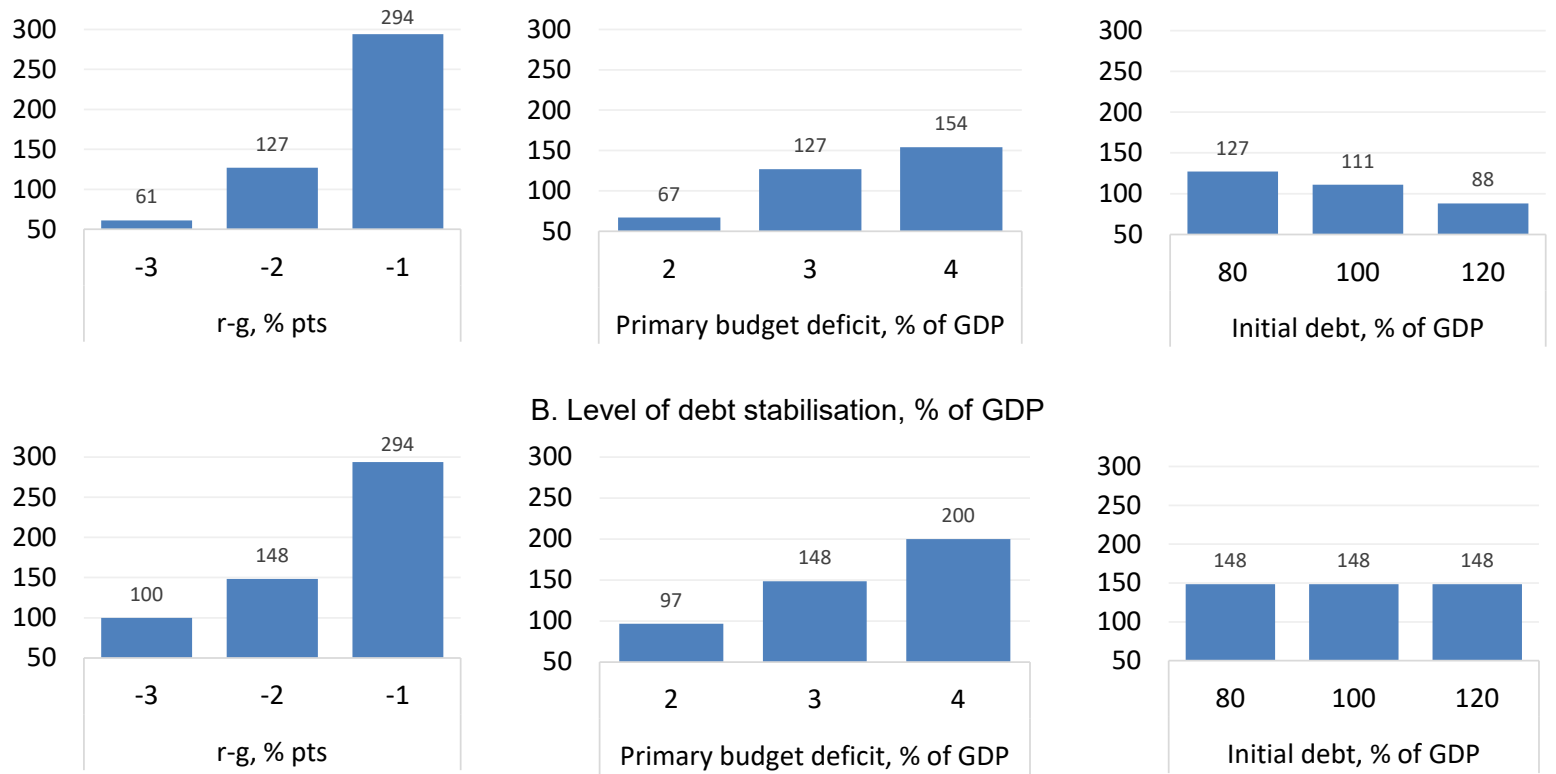

B. Level of debt stabilisation, \% of GDP
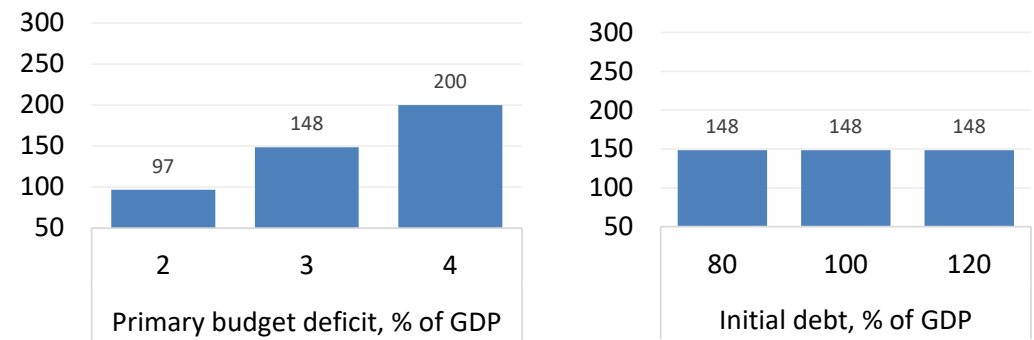

C. Change in debt after 10 years, \% of GDP
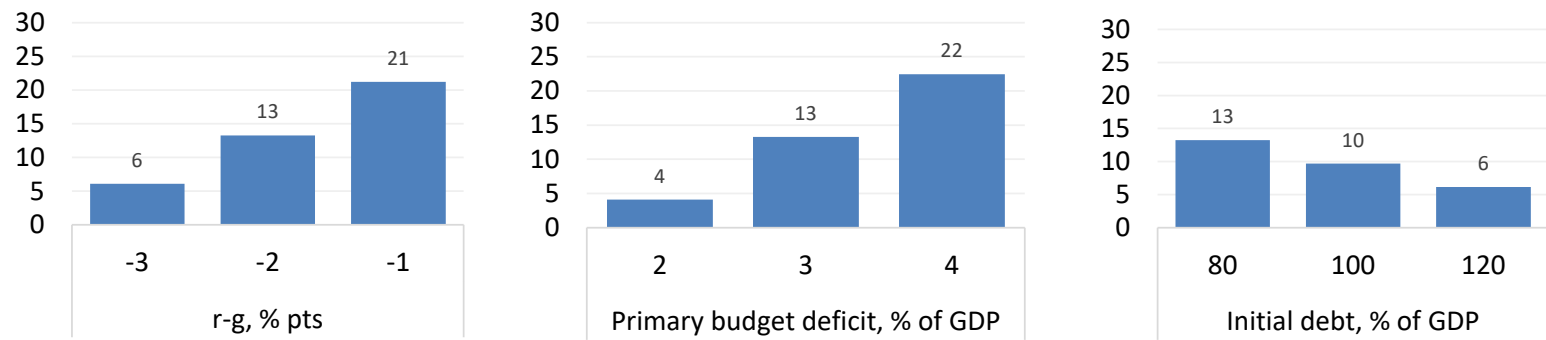

Note: In the left column, simulations assume an initial debt level of $80 \%$ of GDP and a permanent primary budget deficit of $3 \%$ of GDP, with varying $r-g$ (maintained each year) as indicated on the horizontal axis. In the middle column, simulations assume an initial debt level of $80 \%$ of GDP and permanent negative $r-g$ of 2 percentage points, with a varying level of the primary budget deficit (maintained each year) as indicated on the horizontal axis. In the right column, simulations assume a permanent primary budget deficit of $3 \%$ of GDP and permanent negative $r-g$ of 2 percentage points, with a varying level of the initial debt to GDP ratios as indicated on the horizontal axis. Simulations assume no government financial assets and no statistical discrepancy. Debt is assumed to be stabilised when the changes in debt-to-GDP ratio over four years is no higher than $0.5 \%$ of GDP (i.e. usually before the full asymptotic stabilisation).

Source: Authors' calculations. 


\section{Annex D. Measuring pro-cyclicality of discretionary fiscal policy}

This annex assesses the prevalence of pro-cyclical fiscal policy in the OECD countries. It finds that pro-cyclical fiscal policy is quite common across countries and time, but the assessment is sensitive to the measure adopted.

There is no standard definition of pro-cyclical fiscal policy and various approaches to measure the pro-cyclicality of fiscal policy have been used (Égert, 2010 [167]; Sutherland et al., 2010[100]; Carnot and de Castro, 2015[168]). In this annex, fiscal policy is characterised as pro-cyclical when the discretionary fiscal stance is tightened (a positive change in the underlying primary balance; Price, Dang and Botev $\left(2015_{[169]}\right)$ ) and the output gap is negative or vice versa (i.e. the two have opposite signs). By analogy, fiscal policy is deemed counter-cyclical when changes in the underlying primary balance and the output gap have the same sign (e.g. fiscal policy is tightened when the output gap is positive).

By focusing on the level of the output gap, it is not possible to distinguish periods when real GDP growth is high and above potential growth, even if the output gap is negative, from periods when real GDP growth is below potential growth. Thus, an alternative measure of fiscal policy pro-cyclicality compares the change in the underlying primary balance with the change in the output gap. If they have opposite signs, fiscal policy is deemed pro-cyclical.

Estimates of both the underlying primary balances and output gaps are imprecise. The standard cyclical adjustment of budget balances is based on fixed (estimated or calibrated) elasticities of certain categories of government revenues and expenditures with respect to the output gap, that in many cases reflect the situation from the mid-2000 (Price, Dang and Botev, 2015[169]). In practice, these elasticities may vary over time, depending on the composition of GDP growth and the size and nature of a shock, introducing biases in the measure. Consequently, estimates from the 1980 s and the 1990 s may be less reliable given that the structure of public finances and the economies have evolved since then. Moreover, uncertainty about the estimates can be very large during recessions. The larger the shock to income and employment, the more likely that the realised tax and spending elasticities will differ from the historical averages. Finally, uncertainty about the estimated size of the unobservable output gap also compounds uncertainty about the underlying primary balance. This is of concern primarily for the output gap rather than for the change in the output gap, as the level of potential GDP tends to be revised to a larger extent, and more frequently, than the potential output growth rate.

In view of the uncertainty about the assessment of the discretionary fiscal policy stance, a sensitivity check is added to exclude years when absolute changes in the underlying primary balance are smaller or equal to $0.4 \%$ of potential GDP. In other words, within the range between $-0.4 \%$ and $0.4 \%$, changes in the underlying primary balance ratio are not treated as changes in the discretionary fiscal policy stance. For the calculation of frequency, years with small changes in the underlying primary balance are counted. Consequently, the frequency of pro-cyclical and counter-cyclical fiscal policy drops.

Pro-cyclical fiscal policy tends to be common in OECD countries. Taking into account all changes in the underlying primary balance, in three-quarters of the countries, fiscal policy is pro-cyclical more than half the time when using the output gap level as the indicator of the cycle (Figure A D.1, Panel A). The frequency, however, drops significantly when small changes in the underlying primary balance are excluded. Moreover, the incidence of pro-cyclical policy tends to be lower when the output gap is negative (the most adverse form of fiscal policy pro-cyclicality) than when it is positive. However, this is not the case in every country, and this pattern is also less apparent when considering changes in the output gap as 
indicator of the cycle. ${ }^{9}$ When using the change in the output gap instead of the output gap as the indicator of the cycle, pro-cyclical fiscal policy generally tends to be less frequent (Figure A D.1, Panel B).

\section{Figure A D.1. Discretionary fiscal policy tends to be pro-cyclical}

Proportion of years when fiscal policy is pro-cyclical as a per cent of all years and as a per cent of cyclical downswing years (country-specific samples depending on data availability)
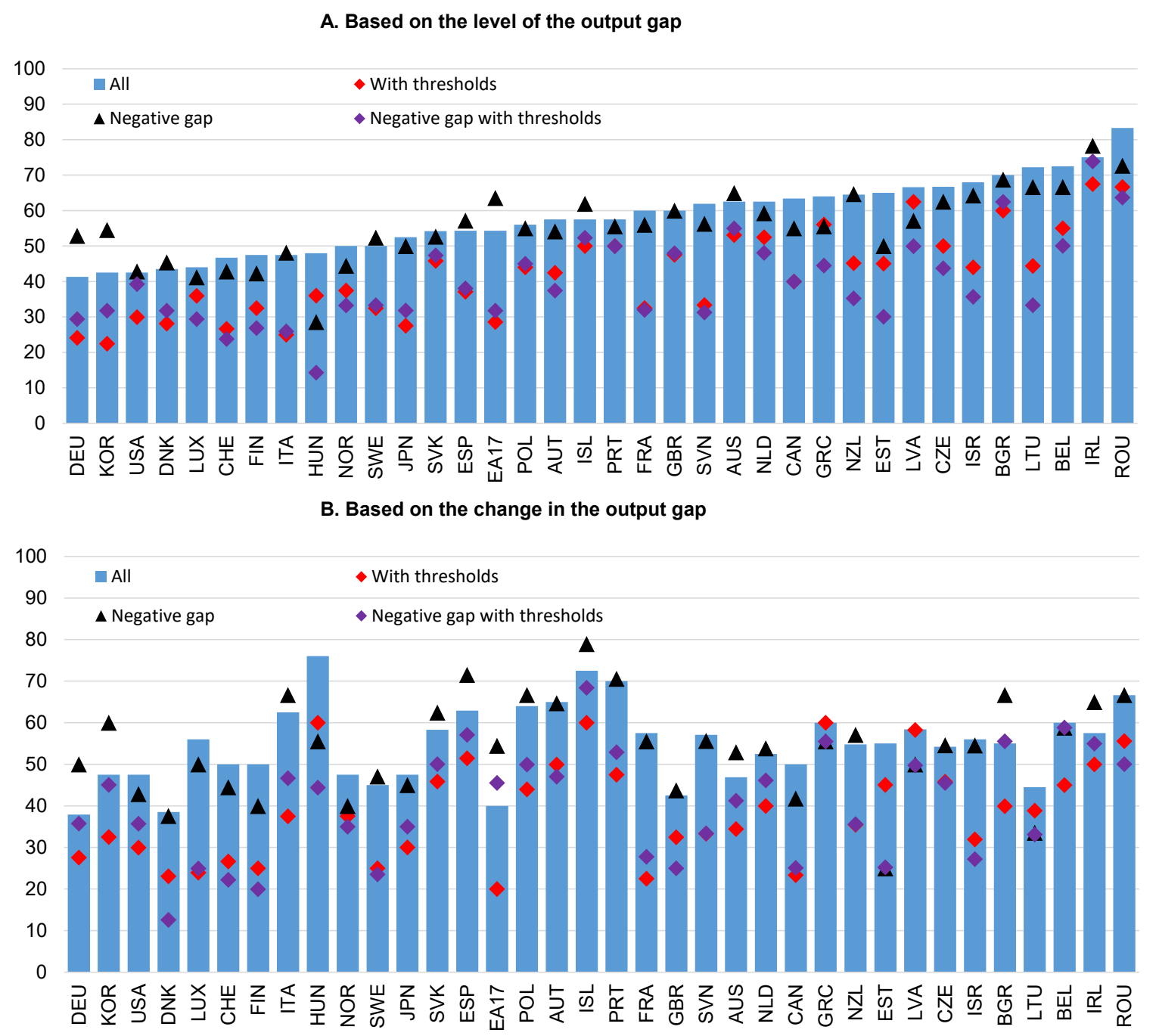

Note: In Panel A, fiscal policy is pro-cyclical when the annual change in the underlying primary balance (as a ratio to potential GDP) and the output gap have opposite signs. In Panel B, this is when the annual difference in the underlying primary balance ratio and the annual change in the output gap have opposite signs. The frequencies of pro-cyclical policy with the negative output gap/change are relative to the years when the output gap/change is negative in the whole sample. The frequencies of pro-cyclical policy with thresholds exclude years when absolute changes in the underlying primary balance are smaller or equal to $0.4 \%$ of potential GDP (frequencies are calculated in relation to the whole sample either with all years or with years when the output gap/change is negative).

Source: OECD Economic Outlook No. 109; and authors' calculations.

\footnotetext{
${ }^{9}$ On average across the countries, such cases account for around $55 \%$ of the time when the output gap is negative, and $60 \%$ of the time when the output gap is positive, but there is large cross-country heterogeneity. Moreover, in two-thirds of the countries, the frequency of pro-cyclical fiscal policy in the total sample is higher than the frequency of pro-cyclical fiscal policy in all years with a negative output gap.
} 
Figure A D.2. Average annual change in the underlying primary balance

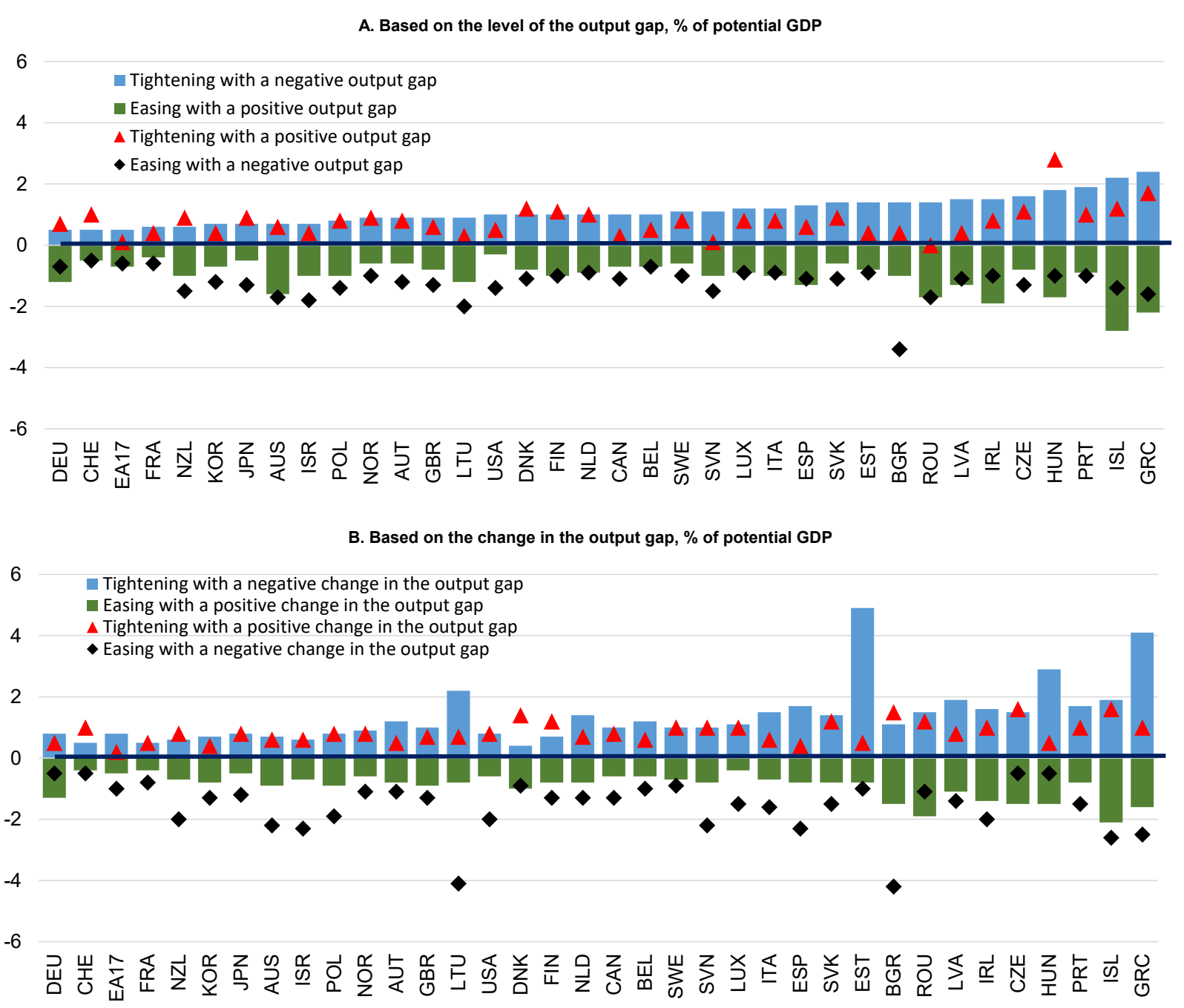

Note: Bars refer to cases of pro-cyclical fiscal policy and markers refer to cases of counter-cyclical fiscal policy. A positive change in the underlying primary balance implies a discretionary fiscal policy tightening, and vice versa. In Panel A, fiscal policy is pro-cyclical when the annual difference in the underlying primary balance (as a ratio to potential GDP) and the output gap have opposite signs. In Panel $B$, this is when the annual difference in the underlying primary balance ratio and the annual change in the output gap have opposite signs.

Source: OECD Economic Outlook No. 109; and authors' calculations.

Regarding the size of changes in the discretionary fiscal policy stance, there are some asymmetries within and among periods when fiscal policy is pro and counter-cyclical. When the cycle is measured by the output gap and fiscal policy is pro-cyclical, the size of fiscal tightening when the output gap is negative tends to be larger than the fiscal easing when the output gap is positive (Figure A D.2, Panel A). However, this difference is smaller when the cycle is measured by the change in the output gap (Figure A D.2, Panel B). Still, fiscal policy is eased by more when the output gap or its change are negative rather than when the output gap or its change are positive. However, in order to assess potential negative effects of discretionary changes in the fiscal policy stance on economic growth in a comprehensive manner, discretionary effects should be compared with automatic stabilisers as the two elements affect GDP. 